\title{
A TAXONOMIC REVISION OF THE LANGURS AND LEAF MONKEYS (PRIMATES: COLOBINAE) OF SOUTH ASIA
}

\author{
Douglas Brandon-Jones
}

32a Back Lane, Richmond, Surrey TW10 7LF, United Kingdom

Email:douglas@quadrumania.net

\begin{abstract}
Over 300 study specimens from Chicago, Kolkata, Leiden, London, Mumbai, New York, Paris and Washington DC are combined with a literature survey to review the taxonomy of Semnopithecus johnii, S. entellus and S. priam. Simia johnii Fischer, 1829 is declared a nomen protectum. The 15 subspecies Ellerman and Morrison-Scott (1966) recognized for Semnopithecus entellus are reduced to seven subspecies for S. entellus and two for S. priam. Type specimens are documented, pelage colour variation described, and the nomenclature and subspecific geographic distributions discussed. Two previously recognized subspecies are reinterpreted as hybrid populations of $\mathrm{S}$. entellus and $\mathrm{S}$. johnii. The central Indian S. entellus anchises, previously suspected as being only an intermediate between subspecies, is found to occupy a substantial discrete distribution. The Himalayan subspecies S. e. schistaceus proves to have a much wider distribution than previously conceived, extending from northwestern Bhutan possibly to Afghanistan. The corollary is that the distribution of $\mathrm{S}$. e. ajax is reduced to three known localities, two of them over $930 \mathrm{~km}$ apart, indicating the intervening occurrence of an as yet unconfirmed high altitude population of this subspecies.
\end{abstract}

\section{KEYWORDS}

Bangladesh, India, langur, Nepal, Pakistan, primates, revision, Semnopithecus entellus, S. johnii, S. priam, subspecies key, taxonomy, zoogeography

\section{AbBreviations}

AMNH - American Museum of Natural History, New York; BNHS - Bombay Natural History Society; CAMP Conservation Assessment and Management Plan; FMNH Field Museum of Natural History, Chicago; ICZN International Code of Zoological Nomenclature; MNHN Muséum National d'Histoire Naturelle, Paris; USNM Smithsonian Institution, Washington, DC; ZD - Natural History Museum, London; ZSI - Indian Museum, Kolkata

This paper springs essentially from an invitation to attend a Conservation Assessment and Management Plan (CAMP) Workshop for South Asian Primates, held at the State Forest Service College, Coimbatore, Tamil Nadu, India, from 5-9 March 2002 (Molur et al., 2003). The organizers recognized the importance of assessing the conservation status of all taxonomically discernible populations, but appreciated the difficulty of accomplishing this aim, given our inadequate knowledge, particularly of some Indian langur subspecies (subfamily Colobinae). Least known is the South-west Indian (Malabar) Langur, but langur subspecific distributions in the Himalaya and central India are far from satisfactorily understood. A manuscript on the Malabar Langur was drafted during the brief interval between the invitation and commencement of the workshop. The deficiencies in our knowledge of langur subspecific distributions became more evident as the workshop progressed, but discussion with the participants, and an impromptu visit to the Annamalai Hills, Tamil Nadu, clarified some of the issues. Seizing the opportunity of the stopover at Mumbai, five days were spent examining the valuable colobine collection accrued by the Bombay Natural History Society (BNHS), including 56 hanuman langur specimens (33 skins and skulls, 10 skins only, and 13 skulls only). Together with the 146 specimens (101 skins and skulls, 13 skins only, and 32 skulls only) at the Natural History Museum, London (ZD); the three skulls at the Odontological Museum, Royal College of Surgeons, London; two skins and skulls, and three skulls at the National Museum of Natural History, Leiden; one skin and skull, and three skins at the American Museum of Natural History, New York (AMNH); the eighteen skins and skulls at the Field Museum of Natural History, Chicago (FMNH); and the seven skins and skulls at the Smithsonian Institution, Washington, DC (USNM); this results in the most comprehensive overview of Indian and Nepal langur taxonomy to date, totalling 246 specimens (169 skins and skulls, 26 skins only, and 51 skulls only). Blyth (1844b; 1848a), Horsfield (1851) and the catalogues of the Indian Museum, Kolkata (ZSI), published by Blyth (1863), Anderson (1881) and Khajuria (1956a) supplied data on a further 23 specimens. Oboussier and Maydell (1960) presented data on an additional 18 specimens, and Kurup (1965) on two more. Material at the Muséum National d'Histoire Naturelle, Paris (MNHN) was only briefly examined and descriptions of most of the eleven specimens are taken from the literature

The Bombay Natural History Society collection proved to include six specimens from Khandala, Maharashtra, India, a locality unrepresented at any of the other above institutions. The peculiarities of these specimens made credible a doubtful central Indian subspecies Semnopithecus entellus anchises Blyth, 1844 whose recognizability inevitably altered the known distribution of other central Indian subspecies, and entailed modification of some of the guidance offered to the workshop. This negated even some of the recent conclusions by Groves (2001) and increased the urgency for a thorough reassessment. Full justice to langur taxonomy must take account of the now extensive literature on langurs. This paper does not purport to be an exhaustive literature review but covers more key references than any predecessor. Some relevant sources may have been overlooked but none, it is hoped, that will significantly affect the taxonomic results. The leaf monkeys of Sri Lanka will be covered in a subsequent broader review. They are subject to less pressing, mainly nomenclatural and geographic, taxonomic issues. 
Overwhelming evidence now segregates about two-thirds of the species formerly amassed in Presbytis Eschscholtz, 1821 into Semnopithecus Desmarest, 1822 (Brandon-Jones, 1984; 1993; 1999; 2001; Groves, 1989; 2001; Corbet, 1992). A consensus divides Semnopithecus into at least two species groups, but their species composition and hierarchical status remain disputed (see Oates et al., 1994; Brandon-Jones et al., 2004). Semnopithecus vetulus and $S$. johnii have been assigned their own genus Kasi Reichenbach, 1862 by Hill (1936; 1937c; 1939) and Pocock (1939) but cranial morphology, neonatal pelage colour and sexually dichromatic pubic integument integrate them with Trachypithecus Reichenbach, 1862. The morphological resemblance between $S$. j. johnii and the Vietnamese $S$. (Trachypithecus) johnii poliocephalus, two residual populations of a single species fragmented by glacially-induced deforestation (Brandon-Jones, 1995; 1996), is closer than that between $S$. johnii and S. vetulus. Vocal analysis (Hohmann, 1988 ) and intermediate pelage colour (see under S. johnii, $S$. priam and $S$. entellus hypoleucos) indicate natural hybridization of $S$. johnii with both $S$. priam and $S$. entellus. The affiliation of $S$. johnii and $S$. entellus in mitochondrial cytochrome- $b$ gene sequences (Zhang \& Ryder, 1998) and their evident hybrid viability corroborate the recent (possibly Holocene) divergence of Semnopithecus from Trachypithecus inferred from morphological, biogeographic and climatological evidence (Brandon-Jones, 1995; 1996). Where genetic and morphological evidence irresolvably conflict, the interests of field and institutional specimen identification and consistent taxonomic treatment of extant and fossil taxa are best served by granting precedence to morphology. Following Brandon-Jones (1984, 1995, 1996), Trachypithecus (including S. vetulus and S. johnii) is therefore recognized only as a subgenus of Semnopithecus.

The supraorbital torus in Trachypithecus rises laterally from glabella to descend again towards the fronto-zygomatic suture, giving the skull a "raised eyebrow" appearance. The nasal aperture is usually sharply angled both at prosthion and at the nasals, but laterally curved, creating a lozenge-shaped outline. In Semnopithecus (sensu stricto) the lower nasal margin is wider and straighter, imparting a shield-shaped outline to the nasal aperture. $S$. vetulus and $S$. johnii tend to be intermediate both in nasal aperture outline and in supraorbital torus which in Semnopithecus is usually relatively level throughout, with a horizontal shelf behind, resembling that of Pygathrix. In most Trachypithecus species the neonatal pelage colour is orange (Brandon-Jones, 1993). In S. johnii it is a dull whitish-orange (pers. obs., Annamalai Hills, 10 March 2002), turning black after three months (A. Sharma, pers. comm.). Hill (1934, p.31) described the $S$. vetulus neonate as varying "from a light silvery grey to leaden grey, and the whiskers, though short at first, are always white from the start". Confirmation is desirable that this pelage colour was observed at birth and not some days later. He added that in all subspecies the rump patch is initially uniform in colour with the rest of the back. The neonate in Semnopithecus (sensu stricto) is dark brown, blackest on the face and paws, suffused with reddish-pink from the underlying skin colour (Pocock, 1928, pl. 1, fig. 3; McCann, 1933, p. 619; Sugiyama, 1966, fig. 3).
Along the superciliary hairline Trachypithecus adults have moderately lengthened black hair and behind it, except in Semnopithecus obscurus shanicus, no frontal whorl. Apart from most $S$. obscurus subspecies where integumental depigmentation removes the contrasting background colour, all Trachypithecus females display an area of varying size, shape and colour (usually white or yellow) of pale pubic skin and hair between and below the ischial callosities. Pelage colour is otherwise so geographically variable that no further subgeneric characters have been identified. Except for females at Ramnagar $\left(27^{0} 44^{\prime} \mathrm{N} 84^{0} 27^{\prime} \mathrm{E}\right)$, Nepal (Chalise, 1995, p. 35), probably referable to $S$. e. schistaceus, sexually dichromatic pubic integument is undetected in Semnopithecus (sensu stricto). All (non-hybrid) adults have a frontal hair whorl, straight projecting black eyebrows and a pale ventral pelage colour. During the first two months of life the pelage gradually becomes much paler so that yearlings are readily distinguished from adults (McCann, 1933, p. 619). Sugiyama (1966, p. 216) specified that the skin turns from pinkish to white-brown about a week after birth and that the pelage begins to turn white shortly after the skin becomes predominantly black at about three months. Infants between 4.5 to five months and 1-2 years are whiter than adults. When describing adult pelage colour, it is therefore necessary to ensure it has passed the transitional condition. The age influence on adult pelage colour suspected by Blyth (1843b, p. 173) and A. Sharma (pers. comm.) is unconfirmed, but there is individual and geographic variation in the intensity and distribution of the yellow or sometimes orange suffusion in the white ventral pelage colour. This pale colour usually extends onto the flank, buttock, back of the thigh and throughout the head, although the back of the head is often darker than the rest of the head. The black hairs sometimes sprinkled on the cheek probably derive from hybridization with $S$. johnii. The tail-tip is often the same colour as the venter, but the rest of the tail is usually pale brownish-grey, sometimes darker and, in hybrids with $S$. johnii, almost black. The dorsal trunk colour ranges from almost white, through orange to dark brown. Very often there is a darker midline band, sometimes most evident between the shoulders, sometimes on the rump. Semnopithecus p. priam, S. p. thersites, S. e. schistaceus and sometimes $S$. e. hector have fairly uniform coloured, relatively pale limbs, while other subspecies have varying degrees of black on the paws, and varying levels to which this dark colour extends from there along the forearm, shank and even onto the anterior part of the thigh. A conical head crest is present only in $S$. p. thersites, $S$. p. priam and adjacent populations of $S$. e. achates.

The apparent allopatry of all known subpopulations has nurtured the view that there is only one species of Semnopithecus (sensu stricto). The morphological divergence between some of the subspecies, however, exceeds for example the distinction between some macaque species. Both Dollman (1913) and through him, Blanford (1888b) influenced Pocock $(1928 ; 1931 ; 1939)$ in defining the 15 S. entellus subspecies Ellerman and Morrison-Scott $(1951 ; 1966)$ assimilated into their checklist of Palaearctic and Indian mammals. Blanford (1888b) and Hill (1939) followed Blyth (1844b) in recognizing four Hanuman Langur species, to which Groves (2001) added three 
more. Brandon-Jones $(1984 ; 2001)$ recognized S. entellus (Dufresne, 1797) and S. hypoleucos Blyth, 1841, the species Blyth (1844b, p. 470; 1847a, p. 361) considered most distinct. It has now become evident that much of its distinctiveness is due to hybridization with $S$. johnii.

The intermediate variation of the larger series since examined of specimens from the Karwar vicinity (Karnataka, India) indicates differences only in pelage colour intensity between S. e. hypoleucos and S. e. achates (Pocock, 1928), undermining their allocation by Brandon-Jones $(1984 ; 2001)$ to separate species. Cercopithecus albo-cinereus Desmarest, 1822, a probable senior synonym of $S$. e. achates has nomenclatural priority over $S$. hypoleucos so, until its identity is settled, only two species are here recognized: $S$. entellus and $S$. priam Blyth, 1844. Seven subspecies are referred to $S$. entellus; two only, $S$. p. priam and S. p. thersites (Blyth, 1848) to S. priam. The hierarchical status of $S$. schistaceus Hodgson, 1841, the fourth species Blyth (1844b) recognized, requires verification. According to Bishop (1979, p. 278), the identical au call at Bhimtal (Uttaranchal, India) and Melemchi (Nepal), confirmed by spectrographs, is currently "the best indication of an isolated Himalayan gene pool".

Over-production has debased the subspecies concept. Pocock (1928) effectively instigated duplicate names for Semnopithecus schistaceus, S. hypoleucos and S. dussumieri, thus automatically halving their credibility. From single specimens Pocock (1928) recognized four of 14 subspecies, and Pocock (1939) similarly recognized three of a slightly adjusted set of 14 subspecies (The fourth singleton subspecies Presbytis lania Elliot, 1909 had become extralimital). Chance can encourage such proliferation. The bulk of a study series may happen to originate from a subspecific boundary where, in addition to the general features of the two or more adjacent populations, there may be an accentuated range of intermediate variation. A disproportion of langur specimens, for example, originated from such a boundary near Karwar. This can over-induce the description of subspecies, or disguise geographic variation as individual variation. Pocock (1939, p. 111), though, candidly asserted that intermediate populations, such as Pithecus entellus elissa Pocock, 1928 and P. e. priamellus Pocock, 1928, merit subspecific recognition.

Accurate documentation of subspecific geographic limits facilitates the taxonomic determination of such intermediate populations. Pocock (1928) offered little or no such guidance for some subspecies, other than the type locality, which he often identified inadequately. Pocock's (1928) spelling mistakes of locality names (as in the type locality of Pithecus entellus achates Pocock, 1928) indicate little attempt at identifying places on a map, in a gazetteer or in the relevant literature, and minimal attention to zoogeography. He manifested some knowledge of the approximate origin of specimens, but often evidently omitted basics, such as consulting the reports of the Bombay Natural History Society Mammal Survey. There is scant sign that Pocock (1928) read round his subject to fill out geographic gaps unrepresented by the museum specimens he examined.
He ignored, for example, T. Hutton's (1868) major paper on langur distribution. Pocock (1939, p. 93) himself acknowledged his redescription of Semnopithecus e. schistaceus but, as Napier (1985, p. 76) related, misidentified its junior synonym. Groves (2001) essentially adopted Pocock's (1939) classification, as modified by Napier (1985), but discarded his duplicate names for $S$. hypoleucos and $S$. dussumieri, and rejected four subspecies apparently based on intermediate populations. Presbytis thersites Blyth, 1848 and P. lania were subsumed, while the remaining seven subspecies were promoted to species.

Pocock's $(1928 ; 1931 ; 1939)$ subspecific classification is not to be dismissed, but leaves much to be desired, particularly in his treatment of the Himalayan langurs, which has caused considerable confusion. His unwarranted treatment of Semnopithecus entellus schistaceus as a nebulous taxon brought all Himalayan langur subspecies into disrepute. Bishop (1979, p. 278), for example, stated: "Taxonomically, these Himalayan populations have been placed into three subspecies: Presbytis (Semnopithecus) entellus achilles (Melemchi; Junbesi), P. e. schistaceus (Bhimtal) and P. e. ajax (Simla) (Pocock, 1939). However, neither behavioral nor morphological evidence can produce a meaningful distinction between these subspecies so a general Himalayan type seems most appropriate at this time". As Bishop (1979) had unwittingly misidentified the subspecies at all four specified localities, her reservations on their recognizability are unsurprising. Her predecessors are not wholly culpable. They could hardly have predicted that the Melemchi langurs would prove to be $S$. e. ajax. Their black hands and fairly dark forearm and metatarsus feature prominently in Bishop's $(1979$, pls. 2, 4) photographs. This apparent eastward range extension of over $930 \mathrm{~km}$ implies either synonymy with $S$. e. schistaceus or, more probably, that the two subspecies have an extensive parallel distribution. Unless Bishop's (1979) monochrome photographs misrepresent the limb colour, the two subspecies must meet near Melemchi because two FMNH specimens from Tarke Ghyang $\left(28^{\circ} 03^{\prime} \mathrm{N}\right.$ $\left.85^{\circ} 33^{\prime} \mathrm{E}\right)$, also in the Helambu Valley, are referable to $S$. $e$. schistaceus. The relatively pale limbs of all 14 Sikkim skins accounted for in the present study discredits the dark paw and forearm colour as individual variation.

Pocock (1928) indiscriminately treated Himachal Pradesh langurs as paratypes of Semnopithecus entellus ajax, interpreting their limb colour variation as purely seasonal or age-related. The seemingly discontinuous distribution created by his justified referral to S. e. schistaceus (originally from Nepal) of two Kashmir specimens (from west of Himachal Pradesh) should have signalled caution. A re-examination of the paratypes indicates geographic variation and the local presence of both subspecies. This study concludes that from at least Melemchi in Nepal, to Kishtwar in the Zanskar region of Jammu and Kashmir, the two subspecies have parallel distributions, which may stretch from Afghanistan to Bhutan. Available evidence currently allows only provisional identification of one subspecies $S$. e. schistaceus (the one at Shimla and probably Junbesi) from Pakistan. A third Himalayan subspecies S. e. hector (the one at 
Bhimtal), whose distributional limits also require confirmation, parallels the other two at least from west Bhutan to Hardwar in Uttaranchal, India. There is no convincing evidence of seasonal pelage colour variation in langurs.

It is staggering how ill-informed we are of geographic variation in the so-called common langur. Perhaps merely to acknowledge this ignorance is some achievement. We cannot confidently identify the Pakistan subspecies, nor assert whether more than one subspecies occurs there. Although extrapolation is possible, no taxonomic information is available for langurs from most of the higher parts of Uttaranchal nor from the lower parts of Himachal Pradesh and Kashmir. We can only speculate on the subspecific identity of the populations between Ranthambhore and Varanasi. The subspecies in southern Kerala is also uncertain. Langurs may be naturally absent there. This paper lends credibility to a central Indian subspecies previously doubted or considered merely a subspecifically intermediate population. Its recognizability begs as many questions on the distribution of the central Indian langur subspecies as it answers. What caused its dispersal to apparently almost split the distribution of another subspecies into a northern and southern population? Sadly, owing to human destruction of habitat, some of these questions may never be answered, but this work can perhaps supply clues to some of the answers.

\section{Indian Hooded Leaf Monkey}

\section{Semnopithecus (Trachypithecus) johnii johnii (Fischer, 1829)}

Simia Leonina Shaw, 1800 (in part)

S[emnopithecus] cucullatus I. Geoffroy Saint-Hilaire, 1830

Semnopithecus ruficeps Martin, 1838 (published in synonymy and therefore unavailable)

Semnopithecus jubatus Wagner, 1839

S[emnopithecus] cephalopterus Blyth, 1844

Pithecus [(Pithecus)] vetulus johni Hill, 1934

Kasi johni Hill, 1936

Presbytis (Trachypithecus) johnii Oates, 1979

T[rachypithecus] johnii Phillips, 1981

\section{Etymology}

The Latin adjective Leonina, meaning "lion-like" and partly based on Macaca silenus, presumably refers to the mane-like whiskers and tufted tail of the holotype. The latinized masculine genitive singular proper noun Johnii, commemorates the original describer of the holotype, [C.S.] John, then a missionary at Tranquebar, Tamil Nadu, India. The International Code of Zoological Nomenclature discourages the latinization of a proper noun by the addition of -ius to produce the genitive -ii (third edition, Appendix D.16b) but if originally so latinized, that spelling must be preserved (Article 33.4). The Latin adjective cucullatus, meaning "hooded or cowled", refers to the contrasting head pelage colour and the overlap of the head hairs onto those of the shoulder. The noun phrase ruficeps, derives from the Latin adjective rufus, meaning "red-haired", and the Latin noun ceps from caput, meaning "head". The name was probably intended for Semnopithecus entellus hypoleucos. The epithet jubatus is a modification of the Latin adjective iubatus, meaning "maned", and refers to the manelike head hair.

\section{Vernacular names}

Kannada: Kari-mushya (Ryley, 1913c, p. 492); Tamil: Karumanthi (Webb-Peploe, 1947, p. 630; A.F. Hutton, 1950, p. 689).

\section{Diagnosis}

Above average size and especially weight for its subgenus Trachypithecus (Brandon-Jones, 1995, pp. 35-36), Semnopithecus johnii johnii is a brown-headed, glossy black subspecies endemic to the southern part of the Western Ghats of India. Specimens from north of the Palakkad Gap seem on average more silver-rumped than do those from the south. $S$. johnii is closely related to $S$. vetulus of Sri Lanka and with that species somewhat intermediate between the two Semnopithecus subgenera. Morphologically, however, it most resembles $S . j$. poliocephalus of Cat Ba Island in northern Vietnam (Brandon-Jones, 1995, pp. 24-25, 28, 31-33). It naturally hybridizes with $S$. priam and $S$. entellus where their ranges meet.

\section{Nomenclature}

The sole basis for the valid and available species-group name Simia leonina Shaw, 1800 (pp. 34-35, fig.17) is a digest of Buffon's (1789, pp. 81-82, pl. 22) description entitled "la guenon à crinière", and a redrawing of his plate. Being the only specimen mentioned by Buffon (1789, p. 81), de Bouillon's captive male is here accepted as the holotype. The description and illustration, however, seem to be based on more than one species. Apart from the tail length of 27 pouces $(730 \mathrm{~mm})$, Buffon's (1789) description accords with the Lion-tailed Macaque, Macaca silenus. His plate strongly resembles the Indian Hooded Leaf Monkey except in the physiognomy of the nose, the considerably lengthened throat hairs and the tufted tail-tip. If the figure is accepted as a true representation of the holotype, these trivial differences could threaten the stability of S. johnii Fischer, 1829 as senior scientific name for the hooded leaf monkey. Brandon-Jones (1995, p.27) recommended the suppression of $S$. leonina under the plenary powers of the International Commission for Zoological Nomenclature. Changes to the International Code of Zoological Nomenclature now enable validation of a potential junior synonym without recourse to the Commission. In accordance with Article 23.9.2, as a precautionary measure, in case it proves to be a junior synonym, S. johnii is here validated and henceforth takes precedence over S. leonina. The lack of use after 1899 of S. leonina Shaw, 1800 as a valid name satisfies one of the two conditions (Article 23.9.1.1) (The junior homonymy of S. leonina Humboldt, 1805 which has been used, is unaffected). At least 25 works (for example, Ali et al., 1953; Fiedler, 1956; Khajuria, 1956a; Ellerman \& Morrison-Scott, 1966; Kuhn, 1967; Napier \& Napier, 1967; Poirier, 1970; Hardy, 1977; Oates, 1979; 1982; Fooden, 1981; Phillips, 1981; Brandon-Jones, 1984; 1993; 1995; 1996; 2001; Hohmann \& Herzog, 1985; Napier, 1985; Balakrishnan \& Easa, 1986; Hohmann, 1988; Groves, 1989; 1993; 2001; Corbet, 1992; Oates et al., 1994; Rowe, 1996; Zhang \& Ryder, 1998; Molur et al., 2003; Brandon-Jones et al., 2004) 
published by at least ten authors over more than ten of the last 50 years (Article 23.9.1.2) have employed S. johnii as the presumed valid name for the hooded leaf monkey. When cited, the younger, but valid name can be qualified by the term nomen protectum and the invalid, but older name by the term nomen oblitum. They are subjective synonyms so, if not regarded as a synonym, the older name may be used as valid.

\section{Type specimens}

The holotype of Simia leonina Shaw, 1800 is an adult male owned by the Duc de Bouillon and living in the Royal Menagerie at Versailles in 1775 (Buffon, 1789, p. 81). The holotype of $S$. johnii Fischer, 1829 is the then evidently live specimen received and described by John (1795, pp. 215-216). Both holotypes have probably been destroyed. The holotype of Semnopithecus cucullatus I. Geoffroy Saint-Hilaire, 1830 is an adult female mounted skin without skull, donated to the Muséum National d'Histoire Naturelle, Paris in July 1822 by Leschenault de la Tour (Rode, 1938, p. 211, no. 21a), and figured by Geoffroy (1831, pl. 1). The "allotype" juvenile male with skull in the skin, listed by Rode (1938, p. 211, no. 21b) is not a paratype because it was received while Geoffroy (1831) was in press (Geoffroy, 1831, p. 74). The syntypes of Semnopithecus jubatus Wagner, 1839 are two specimens collected by Baron [C.A.A.] von Hügel and mounted in the Viennese Museum (Wagner, 1839, p. 305). Their large canines (Wagner, 1839, p. 306) indicate both are adult males.

\section{Type localities}

The type locality of Simia leonina is unknown but, as it reached captivity in France, it is most likely to have originated from the Western Ghats east of the French colony of Mahe $\left(11^{\circ} 42^{\prime} \mathrm{N}\right.$ $\left.75^{\circ} 32^{\prime} \mathrm{E}\right)$ in Kerala, southern India. Nearby Tellicherie $\left(11^{\circ} 45^{\prime} \mathrm{N}\right.$ $75^{0} 32^{\prime} \mathrm{E}$, now Thalassery), the purported type locality of $S$. johnii is, according to Jerdon (1867, pp. 8-9), who resided there, outside the natural range of the species. John's was probably a captive specimen, such as those seen by Bélanger (in Geoffroy, 1831, p.74) on the Malabar Coast. The type locality of Semnopithecus cucullatus is the Ghat mountains. Jerdon $(1867$, p. 8) claimed the holotype was obtained at Mahe, but the "Nellygerry" Hills, visited by the donor of the holotype in May 1819, appear to be the only part of the species' range visited during his expedition to southern India in 1818-1819 (Leschenault de la Tour, 1823). The type locality of $S$. jubatus is the southern part of India. Again, the only part of the species' range the syntype collector reportedly visited is the "Neelgherry" Hills, where he spent a few weeks in March 1832 (Baikie, 1834, p. 40). The type locality of all four species-group names is therefore here restricted to Coonoor $\left(11^{0} 21^{\prime} \mathrm{N} 76^{\circ} 49^{\prime} \mathrm{E}\right)$ in the Nilgiri Hills, from where the National Museum of Natural History, Leiden has a juvenile female mounted skin with skull inside collected in 1875 by M.F. Day (Schlegel, 1876, p. 51; Jentink, 1892, p. 13).

\section{Geographic distribution}

Confined to the southern part of the Western Ghats of southern India from 150-2400m (Oates, 1979, p.487), Semnopithecus $j$. johnii has been reported as far south as within about $3 \mathrm{~km}$ of the Aramboli Pass $\left(8^{0} 16^{\prime} \mathrm{N} 77^{0} 33^{\prime} \mathrm{E}\right)$, Tamil Nadu (Hill, 1937c, p.
208), and as far north as Srimangala $\left(12^{\circ} 01^{\prime} \mathrm{N} 75^{\circ} 58^{\prime} \mathrm{E}\right)$, Karnataka (ZD.1913.8.22.1; BNHS.5186; Ryley, 1913c, p. 492). The specimens brought from Mumbai (Bombay) by Dussumier (in Geoffroy, 1831, p.74) were presumably trade or captive specimens. Contrary to the statement by Poirier (1970, p.257), there is no historical evidence for its existence on the Shevaroy Hills (11050'N 78016'E) (Blanford, 1888b, p.34; Oates, 1979, pp. 487-488). It is absent from the field notes of the mammal section of the Vernay scientific survey of the area in 1929-1930 (Baptista, 1930). The most easterly recorded localities are Machur (=Machchur, $10^{\circ} 16^{\prime} \mathrm{N} 77^{\circ} 35^{\prime} \mathrm{E}$ ) (Lindsay, 1926a, p. 592) and Mudaliar Ootu, near Srivilliputhur (c. $9^{0} 35^{\prime} \mathrm{N} \& 7^{\circ} 35^{\prime} \mathrm{E}$ ) (Johnsingh, 1974, p. 376).

\section{Pelage colour variation}

The head hairs in Semnopithecus j. johnii are recumbent and posteriorly directed. The nuchal hairs are longer than those of the shoulder. The hair length at the flank and at the medium lower thoracic part of the back resembles that of $S$. delacouri, but the hair length on the tail is the shortest of the Asian pied leaf monkeys (Brandon-Jones, 1995). The yellow to orange brown nuchal and/or occipital pelage colour varies individually in its extent, which sometimes includes the brow. The rest of the head and neck is pale brown. Like that of $S . j$. poliocephalus, the glossy black dorsal pelage is basally brown, but in a low altitude locality (c. $8^{0} 41^{\prime} \mathrm{N} 77^{\circ} 22^{\prime} \mathrm{E}$ ) in the most southerly part of its range, some wholly brown individuals with silvery-gold head hair, and some partially brown individuals have been reported (Oates, 1982, p. 308). The holotype of S. cucullatus is possibly one such specimen, but it may be that the brown colour of the "flanks, loins and buttocks" (Geoffroy, 1831, p. 72, pl. 1) has been at least partly exposed by superficial damage to the pelage. Similar specimens observed and photographed by Hohmann and Herzog (1985) in the Nilgiri Hills are brown, with black limb extremities, skin and tail. The cream colour of the head extends onto the shoulders and encircles the face. One probable adult male had a crest resembling that of $S$. priam, while an adult female had the typical female $S$. johnii white thigh patch. The abnormal pelage colour of the $S$. p. priam specimen figured in a monochrome photograph by Hohmann and Herzog (1985, fig. 2) corroborates their conclusion that this is a hybrid population. This crested specimen has a predominantly white foot and predominantly black hand (the left hand apparently blacker than the right). Most unusually its chest other than the midline is blackish.

The presence and extent of the dorsal area with grey distal bands on the blackish hairs is subject to individual, and apparently geographic, variation. Of the Semnopithecus j. johnii specimens from Kodagu (Coorg) and the Nilgiris, silvering of the rump is conspicuous only in ZD.1879.11.21.591 and ZD.1913.8.22.1. In ZD.1845.8.12.2 it is conspicuous only at the most proximal part of the thigh, and only at the tail root in ZD.1891.10.7.7 and in Jentink (1892, p. 13) specimen $d$. In all five specimens faint silvering spreads at least as far as the first third of the tail and is just discernible throughout most of the dorsum except the paws in 1879.11.21.591 and 1891.10.7.7. In juvenile male BNHS.5186, collected (number 2487) on 9 February 
1913 at Srimangala, there is barely discernible silvering for the first $80 \mathrm{~mm}$ above the tail root and on the first $70 \mathrm{~mm}$ of the tail. The remaining localized specimens examined all originate from between $10^{\circ}$ and $10^{\circ} 35^{\prime} \mathrm{N}$. BNHS.5187-5190 are all from about $10^{\circ} 30^{\prime} \mathrm{N} 76^{\circ} 45^{\prime} \mathrm{E}$. BNHS.5187-8 are a subadult male and presumed adult female from the Nelliampathy Hills, collected (no numbers) by A.P. Kinloch on 12 March 1919 and 7 December 1923 (the latter at $3500 \mathrm{ft}(1000 \mathrm{~m}))$, respectively. BNHS.5189-90 are a juvenile female (number 105) and presumed adult male (number 18 , amended to 16), labelled as having been collected in the Cotengady Estate by J.R. O'Brien on 18 May 1921 and April 1922, respectively. Their silvered rumps raise the possibility that they may be mislabelled and be two of the otherwise unaccounted for three specimens collected by A.F. Hutton near the Rousdon Mullai Estate, 1500ft (450m), Devala P.O., in an isolated valley of the southwestern slope of the Wynaad (= Wyanad) Plateau (c. $\left.11^{0} 29^{\prime} \mathrm{N} 76^{0} 24^{\prime} \mathrm{E}\right)$ (Abdulali, 1952; Ali et al., 1953). In all specimens silvering is discernible to a variable extent on the tail and the dorsum except the paws, but is conspicuous in only four specimens, and then only between the tail root and the callosities (ZD.1921.11.5.6) or dorso-lateral to the callosities (ZD.1921.11.5.4-5). BNHS.5190 has pronounced silvering, especially dorso-lateral to the callosities where the hair is almost pure brownish-white. The first half of the tail is more lightly silvered. BNHS.5189 has moderate, but readily perceivable silvering on the rump and proximal half of the tail. In BNHS.5187 an almost circular area of moderate silvering extends $100-120 \mathrm{~mm}$ from the silvered tail root. Silvering is less evident on the rest of the tail. In BNHS.5188 there is a sharp-apexed triangle of silvering around the darker tail root, with some silvering on the tail whose last two-thirds is partially depilated.

Hill (1937c, p. 206), referring to specimens from about $9^{0}$ to $9^{0} 35^{\prime} \mathrm{N}$, reported that in "none of the living specimens I saw, nor in any of the skins, was there a pale sacral patch. The old male in Trivandrum [= Thiruvananthapuram] Zoo had a few whitetipped hairs on either side of the root of the tail". The contrast with the black-rumped individuals of the High Wavy Mountains and higher parts of the Varushnaad Valley $\left(9^{0} 32^{\prime} \mathrm{N} 77^{\circ} 25^{\prime} \mathrm{E}\right)$ (A.F. Hutton, 1950, pp. 689-690), may have accentuated the "greyish white buttocks and thighs" of specimens from the southwestern slope of the Wyanad Plateau (Ali et al., 1953).

The pubic hairs are readily examinable in only three adult male Semnopithecus $j$. johnii specimens and one subadult male. In two there is a pale area about $20 \mathrm{~mm} \times 20 \mathrm{~mm}$ immediately behind the penis. In ZD.1913.8.22.1, it is whitish-brown; in ZD.1879.11.21.591, it is yellowish-white circumscribed by brownish. Such hair appear absent in BNHS.5187 and BNHS.5190. In adult female, ZD.1845.8.12.2, yellowish-white hairs occur between and ventral to the callosities, tapering to about $80 \mathrm{~mm}$ along the thigh and for about $40 \mathrm{~mm}$ along the ventral tail root.

\section{White-handed Crested Langur Semnopithecus (Semnopithecus) priam priam Blyth, 1844} S[emnopithecus] pallipes Blyth, 1844 (nomen nudum) $\operatorname{Pr}[$ esbytis] priamus Blyth, 1847

S[emnopithecus] albipes I. Geoffroy Saint-Hilaire, 1851 Semnop[ithecus] albimanus Schlegel, 1876

Semnopithecus leucoprymnus: Hornaday, 1885 (not Cercopithecus (?) leucoprymnus Otto, 1825)

Pithecus entellus pallipes Pocock, 1928\

\section{Etymology}

Priam, aged king of Troy (or Ilium, near the Dardanelles in modern Turkey) and son of Laomedon, was killed by Neoptolemus (or Pyrrhus), son of Achilles, during the sack of Troy. The similarity between his Phrygian pointed cap and the langur's crest may have occasioned the name. Priam means "the ransomed", his sister Hesione having redeemed him from Hercules (the latinization of Heracles). Priamus is a latinization of Priam. They are masculine nominative singular proper nouns in apposition to the generic name, and are therefore not declined to agree in gender with that of the genus. The noun phrase pallipes derives from the Latin adjective pallidus, meaning "pale", and the Latin noun pes, meaning "foot". The noun phrase albipes derives from the Latin adjective albus, meaning "white", and the Latin noun pes. The noun phrase albimanus derives from the Latin adjective albus, and the Latin noun manus, meaning "hand".

\section{Vernacular names}

Telugu: Gandangi (Jerdon, 1867, p. 7; Baptista, 1930, p. 3); Konda-moochii (probably a copy typist's misreading of "Konda-moochu", see under S. e. anchises) (Baptista, 1930, p. 2); Malayalam: Mandi (John, 1799); Tamil: Mossekundi (Baptista, 1930, p. 1).

\section{Diagnosis}

About average size and weight for Semnopithecus (sensu stricto), S. priam priam is a crested, blond-pawed, yellowishwhite subspecies, suffused with pale greyish-brown on the crown, back, arm, upper thigh and backward-looped tail. It inhabits Tamil Nadu, south Andhra Pradesh and southeastern Karnataka in southern India. It intergrades to the south with $S$. $p$. thersites, to the west with $S$. hypoleucos, to the north-west with $S$. entellus achates and in the extreme north-east of its range with $S$. e. anchises. It most resembles $S$. p. thersites, which Groves (2001) believed a junior synonym. It hybridizes with $S$. j. johnii in the Nilgiri Hills.

\section{Nomenclature}

As Pocock (1928, p. 498) detected, S[emnopithecus] pallipes Blyth, 1844 predates $S$. priam Blyth, 1844 by at least six months. Blyth (1844a), however, stated only that $S$. pallipes is distinct from the Bengal entellus monkey and occurs in southern India. Article 12.3 of the International Code of Zoological Nomenclature expressly excludes the mention of a locality alone as constituting a description, definition or indication. S. pallipes Blyth, 1844 therefore is a nomen nudum. Pocock (1928, pp. 495498), however, validated it as an objective junior synonym of $S$. 
priam Blyth, 1844. S. albimanus Schlegel, 1876 (p. 32) is probably a nomen nudum because its description appeared on the following page where Schlegel (1876, p. 33) acknowledged his error in so naming it, indicating the two pages were published separately.

\section{Type specimens}

Before 15 December 1843 (Blyth, 1844a), W. Elliot donated "three examples of $S[$ emnopithecus] priam" (Blyth, 1844b, p. 470) to the Museum of the Asiatic Society of Bengal but Blyth (1847b, p. 732) recorded only a "nearly full grown" syntype. A syntype donated to the Museum of the Hon. East-India Company, London (Horsfield, 1851, p. 7), was apparently not transferred to the British Museum (Natural History) in 1879 (Napier, 1985), and its fate is unknown. The third syntype is probably the paratype of Presbytis thersites Blyth, 1848. Anderson (1879, p. 19) alluded to "the two types of $S$. priamus" but, as only one is a syntype, he effectively designated it as lectotype of $S$. pallipes Blyth, 1844, S. priam Blyth, 1844 and P. priamus Blyth, 1847. Figured by Blyth (1848a, pl. 54, fig. 2) in a water-coloured lithograph, it is a skull and mounted skin ZSI.11984, preserved at the Indian Museum, Kolkata. Khajuria (1956a, p. 199) sexed it as male but Blyth $(1847 \mathrm{~b}$, p. $732 ; 1863$, p. 12, 30A) and Anderson (1881, p. 38, 12a) sexed it as female. Anderson's (1879) spurious type specimen from Point Pedro, Sri Lanka, was received from E.L. Layard in 1848 (Blyth, 1863, p. 12, 30B; Anderson, 1881, p. 38, 12b; Khajuria, 1956a, p. 200, ZSI.11833). Rode (1938, p. 209, no. 13a) listed the adult male mounted skin with skull inside, collected by the Danaïde expedition and donated by the Naval Officer, M[onsieur] Jaurès in May 1843 to the Muséum National d'Histoire Naturelle, Paris, as the "holotype" of S. albipes Geoffroy, 1851 (and its objective junior synonym, S. albimanus Schlegel, 1876), thus effectively designating it as the lectotype. The immature female mounted skin with skull inside, listed as "allotype" by Rode (1938, p. 209, no. 13b), is the sole paralectotype (Geoffroy, 1851a, p. 14; 1851b, p. 539).

\section{Type localities}

The lectotype and probably one paralectotype of S[emnopithecus] pallipes, S. priam and $\operatorname{Pr}[$ esbytis] priamus were collected on the Coromandel coast, India (Blyth, 1844b, p. $470 ; 1847$ b, p. 732). [Blyth] (1845) included a presumably adult specimen with this locality in a corrected list of 8 April 1845 of mammals donated by the Asiatic Society of Bengal to the Museum of the Hon. East-India Company, London. Either the list or more probably the collection was received on 10 November 1845. "Coromandel" can be restricted to Chennai $\left(13^{\circ} 05^{\prime} \mathrm{N} 80^{\circ} 17^{\prime} \mathrm{E}\right.$, formerly Madras), Tamil Nadu, where W. Elliot (1839) served in the Madras Civil Service. The other paralectotype was apparently from Sri Lanka. The lectotype and paralectotype of $S$. albipes and $S$. albimanus were purportedly collected in Manille (= Manila, Philippines) (Geoffroy, 1851a, p. 14; 1851b, pp. 536, 539). [C.G.] Semper (18321893) travelled in the Philippines from December 1858 to May 1865 (Schuberg, 1895). He assured Schlegel (1876, p. 32) that colobines were absent from most Philippine islands but that a species, he presumed this one, was widespread on the island of Solo (= Jolo, Sulu Archipelago, Philippines). The only monkey recorded from Jolo is Macaca fascicularis (see Bourns \& Worcester, 1894, pp. 6, 61). It is inconceivable that $S$. priam has the disjunct geographic distribution implicit in its purported occurrence on Jolo. It is therefore inferred that in the course of its voyage the Danaïde either docked in India where specimens were obtained whose provenance later became confused or that perhaps captive specimens were acquired in Manila in ignorance of their Indian origin. The type locality of $S$. albipes and $S$. albimanus is here provisionally restricted to the then French colony of Pondicherry $\left(12^{\circ} 00^{\prime} \mathrm{N} 79^{\circ} 50^{\prime} \mathrm{E}\right)$, Tamil Nadu, India.

\section{Geographic distribution}

Baptista (1930, pp. 1, 2, 5-6) collected Semnopithecus p. priam at Hogainakal (= Hogenakal Falls, $\left.12^{\circ} 07^{\prime} \mathrm{N} 77^{\circ} 46^{\prime} \mathrm{E}\right), 850 \mathrm{ft}(260 \mathrm{~m})$, Muthur (c. $\left.12^{\circ} 10^{\prime} \mathrm{N} 77^{\circ} 40^{\prime} \mathrm{E}\right), 950 \mathrm{ft}(290 \mathrm{~m})$, and Tirthamalai (= Tirttamalai, $\left.12^{\circ} 06^{\prime} \mathrm{N} 78^{\circ} 36^{\prime} \mathrm{E}\right), 1000 \mathrm{ft}(300 \mathrm{~m})$, Salem Dist[rict]. He reported it abundant around Kondagorlapenta $\left(14^{0} 22^{\prime} \mathrm{N} 78^{\circ} 55^{\prime} \mathrm{E}\right)$ in August and September, and that a favourite langur haunt was a forest of tall mango trees along the river Sangli at Malakondapenta (c. $\left.15^{0} 30^{\prime} \mathrm{N} 78^{\circ} 50^{\prime} \mathrm{E}\right), 1050 \mathrm{ft}(320 \mathrm{~m})$. Given the intermediate specimens from Dasarladoddi (c. $\left.14^{0} 15^{\prime} \mathrm{N} 78^{0} 50^{\prime} \mathrm{E}\right)$, $1600 \mathrm{ft}(490 \mathrm{~m})$ and Diguvametta $\left(15^{\circ} 23^{\prime} \mathrm{N} 78^{0} 50^{\prime} \mathrm{E}\right), 1030 \mathrm{ft}(310 \mathrm{~m})$ (Baptista, 1930, pp. 1-3; Pocock, 1931, pp. 52-54; Napier, 1985, pp. 80-81), the Malakondapenta population may be attributable to $S$. e. anchises. Similarly, the identity of the "exceedingly numerous" (Jerdon, 1867, p. 7) langurs at Bangalore $\left(12^{\circ} 58^{\prime} \mathrm{N}\right.$ $\left.77^{0} 30^{\prime} \mathrm{E}\right)$ requires confirmation. That they may be $S$. e. achates is intimated by the apparent hiatus in langur distribution at Kolar $\left(13^{\circ} 08^{\prime} \mathrm{N} 78^{\circ} 08^{\prime} \mathrm{E}\right)$ (Shortridge, in Ryley, 1913a, p. 285). The seemingly white hand with a small amount of grey on the knuckle of a single langur photographed by P.O. Nameer (in litt.) in April 1999 indicates S. p. priam is present at Chinnar Wildlife Sanctuary (c. $\left.10^{\circ} 18^{\prime} \mathrm{N} 77^{\circ} 16^{\prime} \mathrm{E}\right)$, Kerala. John (1799) saw it at Tiruwallur (= Tiruvalur, $\left.10^{\circ} 46^{\prime} \mathrm{N} 79^{\circ} 39^{\prime} \mathrm{E}\right)$. Jerdon $(1867$, p. 7 ) reported seeing it near Trichinopoly (= Tiruchirappalli, $10^{\circ} 49^{\prime} \mathrm{N}$ $\left.78^{\circ} 41^{\prime} \mathrm{E}\right)$ and near Nellore $\left(14^{0} 26^{\prime} \mathrm{N} 79^{\circ} 58^{\prime} \mathrm{E}\right)$ and that it was often domesticated at Chennai.

According to Davison (in Blanford, 1888b, p. 32) Semnopithecus priam ascends the eastern slopes of the Nilgiris to $6000 \mathrm{ft}$ (1800m). Hohmann and Herzog (1985, fig. 2) reported it very rare in the Nilgiri mountain area, occurring mainly near human settlements. Fletcher (1911, p. 427) rated it rare on the Wyanad Plateau (c. $11^{\circ} 29^{\prime} \mathrm{N} 76^{\circ} 24^{\prime} \mathrm{E}$ ) but common below $300 \mathrm{~m}$ in the Ghats forests. On 26 May 1877, W.T. Hornaday collected (number 2367) adult female skull and round skin, USNM.122634 in the "Neilgherry Dist[rict]". This specimen was shot in the forest along the Moyar River near the Tippecadu (= Theppakadu in Mudumalai Wildlife Sanctuary, $11^{0} 35^{\prime} \mathrm{N} 76^{0} 35^{\prime} \mathrm{E}$, Tamil Nadu) traveller's bungalow, $35 \mathrm{~km}$ from Udhagamandalam (Hornaday, 1885, pp. 106-107). Its iris was ashy brown, its callosities pale "drab", and its facial, ear and palmar skin black. The eyebrows are black; the periphery of the fingers somewhat black. Otherwise it is pale greyish-brown, darkest in the middle of the tail (where it is yellowish-black), with a pale yellowish suffusion, deepest and most streaky on the brachium and upper back, and 
least evident on the forearm. The crown only of the head is pale brown. The rest of the body, including the tail-tip is whitishyellow, most orange just below the nipples. On 3 September 1947, [S.D.] Ripley collected (number 122) adult female round

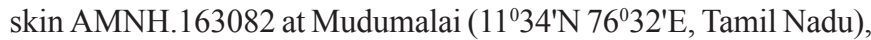
$3285 \mathrm{ft}(1000 \mathrm{~m})$, "base of Nilgiris". It resembles a pale $S$. entellus achates with the paws barely darkened. The crown and upper back are very blond. The apparently grey hands with black fingers of langurs photographed in colour there in January 2001 by P.O. Nameer (in litt.) raises the possibility that the Mudumalai Wildlife Sanctuary lies on the boundary between $S$. p. priam and $S$. $p$. thersites, but local intergradation with $S$. e. achates is more probable.

Adult female round skin AMNH.112980 from Billigirirangan Hills (= Biligiri Rangan Hills, $11^{0} 54^{\prime} \mathrm{N} 77^{0} 14^{\prime} \mathrm{E}$ ), with no other data but possibly associated with skull A.70.19 from the Honnametti Estate, preserved at the Royal College of Surgeons, London (Napier, 1985, p. 80), tends to confirm Shortridge's surmise (in Ryley, 1913a, p. 284) that the langur said to exist on the Coimbatore side of the Cauvery River at Sivasamudram (Cauvery Falls, $12^{0} 16^{\prime} \mathrm{N} 77^{\circ} 10^{\prime} \mathrm{E}$, Karnataka) is "Presbytis priamus". It is pale greyish-brown including the hand, but most of the foot is whitish except for the mid phalanx of each toe. There is slight darkening at the wrist. The head is almost blond, tinged with pale brown in the centre of the crown, but less so in the centre of the nape. The tail is darker brown than the rest of the dorsum but intermingled with the whitish which envelops the venter. This discredits "the Coimbatore district or its vicinity" (c. $11^{0} 15^{\prime} \mathrm{N}$ $\left.77^{0} 20^{\prime} \mathrm{E}\right)$ as the source of the imperfect juvenile skin sent by W. Elliot (Blyth, 1844b, p. 471). Its resemblance to the Vijayanagar Semnopithecus entellus achates paratypes (see under S. e. anchises) indicates an origin in the Bellary District, Karnataka. It lacked the frizzy hair, which according to Blyth (1844b) distinguishes $S$. e. entellus from both $S$. e. anchises and $S$. $p$. priam, but had the pelage colour and well-marked black paws of S. e. entellus. Blyth (1844b, p. 470) described the body areas of $S$. e. entellus that are not "pale chocolat au lait" as "light straw-colour, or pale isabelline, with occasionally a tinge of ferruginous on the belly". If the boundary continues along the Kabini River, the small troops Nolte (1956, p. 182) saw near Byrankuppe (= Bylakuppe, c. $11^{0} 45^{\prime} \mathrm{N} 76^{0} 15^{\prime} \mathrm{E}$ ) may (like the Nagarhole population, see under $S$. e. achates) be intermediate between $S$. p. priam and $S$. e. achates.

In 1983, Sally Walker (in litt., 31 March 2002) photographed an adult female (died 23 July 1987) and a juvenile male (died 19 December 1991) captured at Madura Coats, Udhagamandalam (Ooty) and received at the Arignar Anna Zoological Park, Vandalur, Chennai on 4 August 1983. Except in the relatively pale thigh, the adult most resembles Semnopithecus entellus hypoleucos but its dark flank, dark tail-tip (the latter admittedly subject to individual variation), and both its and the juvenile's apparent dark ventral pelage colour indicate they are (natural) $S$. p. priam x S. johnii hybrids. The presence of a crest (quite pronounced in the juvenile, which in most respects resembles Nagarhole specimens), the relatively pale thigh, and the marked external differences between the adult and juvenile (assuming they were both from the same locality) support this conclusion.

\section{Pelage colour variation}

Anderson (1879, p. 19) described Coromandel Semnopithecus priam "specimens" (the lectotype was the only one listed by Anderson, 1881) as dorsally pale ashy grey, darkest on the back and tail. The tail pales towards its somewhat tufted extremity. The paws, venter, inside of the limbs, side of the head, nape and lower half of the thigh are yellowish. The outside of the arm and rest of the thigh resemble the trunk in colour. In the lectotype, Anderson (1881, p. 38) specified that the upper part of the trunk and head is pale "fuliginous" (sooty, dusky), almost yellow on the nape, and palest on the head, darkening towards the rump. The outside of the arm and upper thigh are pale ashy brown. Other body parts, including the paws, throat and side of the head are yellow. Blyth (1844b, p. 470) contradictorily insisted the yellow of $S$. e. entellus is absent. The "chocolat au lait" is paler, but extends throughout the back, outside of the limbs and onto the crown, being, as usual, most intense on the rump. The paws match the rest of the limbs in pallor. The whiskers and occiput are white, and a distinctive short erect crest erupts from the vertex. Cotton wool inserted between the skull and skin through an incision in the vertex, discovered when Anderson (1879, p. 19) removed the skull from the lectotype skin, indicated to him the crest was artificial. The relaxation of the skin in fluid necessary for this procedure may have leached preservatives from the inside, increasing the apparent yellowness of the pelage which had probably been increased by prolonged museum display.

\section{Grey-handed Crested Langur}

Semnopithecus (Semnopithecus) priam thersites (Blyth, 1848)

Pithecus hypoleucos: Kinloch, 1923

Pithecus entellus anchises: Lindsay, 1926

Pithecus entellus priamellus Pocock, 1928

\section{Etymology}

Thersites was a physically deformed, exceptionally ugly and insubordinate Greek warrior, killed by Achilles for deriding his amorous interest in the corpse of the Amazon Queen Penthesilea, Achilles' young, brave and beautiful battle victim. The ensuing outrage forced Achilles to atone for Thersites' murder by sailing for Lesbos to sacrifice to Apollo. Priamellus is a latinized diminutive of Priam (see under S. p. priam). It and Thersites are masculine nominative singular proper nouns in apposition to the generic name. They are therefore not declined to agree in gender with that of the genus.

\section{Vernacular names}

Sinhala: Ellee Wanderoo; Kondé Wanderoo (Kelaart, 1850, p. 201); Elli Vandura; Konde Vandhura; Vandhura (Phillips, 1981, p. 129). Kelaart (in Blyth, 1851, p. 154) gave Maha (great) Wanderoo and Sadoo (white) Wanderoo but Kelaart (1853, p. 2) referred the former name to Semnopithecus vetulus monticola. Hindi: Hunumán (Baker, in Blyth, 1859, p. 283, footnote). Malayalam: Manthi (Wroughton, 1921, p. 550). Tamil: Mundi; Mundi-kurangu (Phillips, 1981, p. 129); Vellai manthi (WebbPeploe, 1947, p. 631); Vella Manthi (white monkey) 
(ZD.1923.1.20.1; Wroughton, 1921, p. 550; A.F. Hutton, 1950, p. 689); Vella Munthee (Baker, in Blyth, 1859, p. 283, footnote); Velle Mandi (Kinloch, 1923, p. 552).

\section{Diagnosis}

Below average size and weight for Semnopithecus (sensu stricto), S. priam thersites is a crested, grey-pawed, yellowishwhite subspecies, suffused with greyish-brown on the crown, back, arm, upper thigh and backward-looped tail. It inhabits southern India (southern Tamil Nadu and southern Kerala), northern and eastern Sri Lanka. It intergrades to the north with $S$. $p$. priam and probably to the north-west with $S$. entellus hypoleucos. It is sympatric with $S$. vetulus philbricki but to the south-west (in the past, if no longer) it probably intergrades with $S$. v. vetulus. It most resembles $S$. $p$. priam, which Groves (2001) believed a senior synonym. It apparently naturally hybridizes with $S$. j. johnii where their ranges meet. Recognized by Pocock (1939) and by Napier (1985) but subsumed into $S$. dussumieri by Groves (2001), Pithecus entellus priamellus Pocock, 1928, which conforms in general pelage colour, is included as a junior synonym but its dark grey hand and possible lack of a crest indicate it is intermediate with $S$. $e$. hypoleucos.

\section{Taxonomic status}

Blyth (1848a, p. 1271) considered Semnopithecus priam thersites primarily distinguished from $S$. $p$. priam by its sharply contrasting white beard. The holotype having become "quite gentle and extremely fond of being caressed", on closer scrutiny Blyth (1848c, p. 249, footnote) perceived "that he has not the radiating centre of hair above the brows [of] other Entelloid Indian Monkeys, while the hair of the crown is particularly dense and touffu [bushy, tufted], though without rising into a crest". This prompted Blanford (1888a, p. 627; 1888b, p. 35) to suggest that Presbytis thersites is a subspecies of $S$. vetulus. Hill (1937a, p. 208) borrowed the holotype for examination at Colombo and agreed the head hairs are not transversely erect "but there is a distinct suggestion of the longitudinal crest normally manifest in priamus, though it is not raised up to a peak as in normal individuals". In other respects, including cranial morphology, he referred it to Semnopithecus (sensu stricto). He disputed Blyth's (1851, p. 154) assertion that the frontal whorl is absent.

Pocock (1939, p. 115) distinguished Semnopithecus priam thersites from $S$. p. priam "on average at least" merely "by its smaller size and generally darker hue". The condylobasal lengths of the two British Museum specimens from near Cape Comorin, Tamil Nadu, India (see below), indicated to Pocock (1939, p. 111) the presence of a third intermediate subspecies. A geographically more comprehensive skull sample might still prove inconclusive. Without it the geographic boundary between such weakly defined subspecies is almost indeterminable. In her identification key, however, Napier (1985, p. 77) distinguished $S$. p. priam by its hand being whitish rather than resembling the back in colour or paler, and by the nape being conspicuously rather than scarcely paler than the crown patch and back. The present study finds exclusively pale-naped specimens not only to the north, but also to the south of a roughly triangular area of dark-naped specimens. This triangle extends from Cape Comorin (= Kanniyakumari, $8^{\circ} 05^{\prime} \mathrm{N} 77^{\circ} 40^{\prime} \mathrm{E}$ ) to Tirttamalai $\left(12^{\circ} 06^{\prime} \mathrm{N} 78^{\circ} 36^{\prime} \mathrm{E}\right)$ in Tamil Nadu and to Mankeni $\left(8^{\circ} 01^{\prime} \mathrm{N} 81^{\circ} 29^{\prime} \mathrm{E}\right)$ in eastern Sri Lanka. Both dark- and pale-naped specimens occur at Mankeni, Cheddikulam $\left(8^{\circ} 40^{\prime} \mathrm{N} 80^{\circ} 18^{\prime} \mathrm{E}\right)$, Kala Oya $\left(8^{\circ} 12^{\prime} \mathrm{N} 80^{\circ} 06^{\prime} \mathrm{E}\right)$ and Tammannewa $\left(8^{\circ} 13^{\prime} \mathrm{N} 80^{\circ} 07^{\prime} \mathrm{E}\right)$ in northern Sri Lanka. Southern localities yielding exclusively pale-naped specimens are Arugam Bay $\left(6^{0} 51^{\prime} \mathrm{N} 81^{\circ} 50^{\prime} \mathrm{E}\right)$, Elahera (about $16 \mathrm{~km}$ south of, c. $\left.7^{0} 40^{\prime} \mathrm{N} 80^{\circ} 45^{\prime} \mathrm{E}\right)$, Hambantota $\left(6^{\circ} 07^{\prime} \mathrm{N}\right.$ $\left.81^{\circ} 07^{\prime} \mathrm{E}\right)$, Kirinda $\left(6^{0} 13^{\prime} \mathrm{N} 81^{\circ} 20^{\prime} \mathrm{E}\right)$, Ranna $\left(6^{\circ} 06^{\prime} \mathrm{N} 80^{\circ} 52^{\prime} \mathrm{E}\right)$, Telulla $\left(6^{0} 36^{\prime} \mathrm{N} 81^{\circ} 08^{\prime} \mathrm{E}\right)$, and Welligatta $\left(6^{\circ} 12^{\prime} \mathrm{N} 81^{\circ} 12^{\prime} \mathrm{E}\right)$. Fifteen specimens from Mankeni were examined and seven from Cheddikulam. Larger series from other localities may reveal similar variation but all six FMNH skins from Kalukelebe $\left(7^{0} 46^{\prime} \mathrm{N}\right.$ $81^{\circ} 02^{\prime}$ E) have dark napes. Nuchal pelage colour is thus an inappropriate subspecific character for $S$. priam, unless three subspecies are recognized.

Specimens from the northern part of the distribution of Semnopithecus priam do tend to have whiter hands. Available evidence is inadequate to establish whether the darker hands of southern Tamil Nadu specimens (here provisionally referred to $S$. $p$. thersites) are subspecifically diagnostic or due to hybridization with $S$. entellus or $S$. johnii. Probably based wholly or largely on the presence or absence of a crest and perhaps a frontal whorl, Blyth (1851, p. 153) reported S. p. priam "common in the Jaffna peninsula at the extreme north of [Sri Lanka] and probably to some distance further south" but replaced by $S . p$. thersites "generally over the low northern half of Ceylon". Anderson (1881, pp. 38-39), however, specified that ZSI.11833 from Point Pedro $\left(9^{0} 50^{\prime} \mathrm{N} 80^{\circ} 14^{\prime} \mathrm{E}\right)$ on the Jaffna peninsula is much darker than the lectotype of $S$. p. priam with a yellowish nape and "upper surface of hands showing a distinct tendency to dusky". It is inferred that only $S$. p. thersites occurs in Sri Lanka, unless a pale-naped Sri Lankan subspecies is recognized.

\section{Type specimens}

The holotype of Presbytis thersites Blyth, 1848 is an adult male donated alive to the Museum of the Asiatic Society of Bengal by "W. Elliot, Esq. (1845)", figured by Blyth (1848a, pl. 54, fig. 3) in a water-coloured lithograph and by Hill (1937a, pl. 7) in a monochrome photograph, and preserved as a skull and round skin at the Indian Museum, Kolkata (Blyth, 1863, p. 12, 30c; Anderson, 1881, p. 39, 12c; Khajuria, 1956a, p. 200, ZSI.11857). As Blyth (1848a) first announced it in the Proceedings of the Asiatic Society of December 1847, it was probably received in that year. "Judging from a not very good skin of a half grown animal examined some time ago" Blyth (1848a, p. 1271) had considered $S$. $p$. thersites identical to $S$. $p$. priam. He added that the crown and body of $S$. $p$. thersites "are darker than in Pr. priamus (as I remember was the smaller specimen which I examined formerly)". The cited juvenile specimen is the sole paratype of $P$. thersites and is also evidently the second paralectotype of $S$. priam donated by W. Elliot. Its loss perhaps caused Blyth (1863, p. 12) to forget that R. Templeton (Blyth, $1848 \mathrm{a} ; 1848 \mathrm{c})$ donated the holotype of $P$. thersites, possibly 
transmitted through W. Elliot who Blyth (1848a; 1851; 1863) credited as the author of the scientific name. The holotype of Pithecus entellus priamellus Pocock, 1928 is an adult male skull and round skin ZD.1921.11.5.7, collected by J.R. O'Brien and preserved at the Natural History Museum, London (Lindsay, 1926a, p. 592; Pocock, 1928, p. 494; Napier, 1985, p. 82 ). Its collector's number 169 (also NN12) between the numbers 162 and 173 of the Funambulus wroughtoni $(=$ F. tristriatus: Corbet, 1992, p. 281) squirrel specimens ZD.1921.11.5.11-12 indicates it was collected between 2 and 6 June 1921.

\section{Type localities}

The holotype of Presbytis thersites was received from "Ceylon" (Blyth, 1848a, p. 1271), restricted by Blyth (1848c, p. 249, footnote) to "the low country of the northern half of Ceylon", and further restricted by Layard (1850, p. 62) to "the neighbourhood of Trincomalie" (= Trincomalee, $8^{0} 34^{\prime} \mathrm{N} 81^{\circ} 14^{\prime} \mathrm{E}$, Sri Lanka). Edgar Layard informed Kelaart (1853, p. 5) that Templeton obtained the holotype from Trincomalee. The holotype of Pithecus entellus priamellus was collected at Shernelly (= Sharnelli Estate, $10^{\circ} 32^{\prime} \mathrm{N} 76^{\circ} 40^{\prime} \mathrm{E}, 500 \mathrm{~m}$, Nelliampathy Plateau, see Fooden, 1981, p. 44), Cochin (Kerala) (Lindsay, 1926a, p. 592; Pocock, 1928, p. 494; Napier, 1985, p. 82), India.

\section{Geographic distribution}

In Sri Lanka, Semnopithecus priam thersites is geographically restricted to the north and east of the island. At about $5000 \mathrm{ft}$ (1500m) (Wroughton, 1915a, p. 81), the highest altitude recorded is in the Ambawela Tea Estates $\left(6^{0} 54^{\prime} \mathrm{N} 80^{\circ} 50^{\prime} \mathrm{E}\right)$ (Wroughton, 1915a, p. 84; Khajuria, 1956a, p. 200, ZSI.12142), which are one of the most south-westerly known localities. Others are

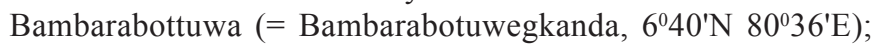
Kala Oya $\left(8^{\circ} 12^{\prime} \mathrm{N} 80^{\circ} 06^{\prime} \mathrm{E}\right)$ (BNHS.5152; Wroughton, 1915a, p. 84; Napier, 1985, p. 83); rocks of Dambool (= Dambulla, $7^{0} 51^{\prime} \mathrm{N}$ $\left.80^{\circ} 39^{\prime} \mathrm{E}\right)$; Hewahette (= Hewaheta, $\left.7^{0} 06^{\prime} \mathrm{N} 80^{\circ} 46^{\prime} \mathrm{E}\right)$; Kaduganava (= Kadugannawa, $\left.7^{0} 15^{\prime} \mathrm{N} 80^{\circ} 31^{\prime} \mathrm{E}\right)$; Matelle (= Matale, $7^{\circ} 28^{\prime} \mathrm{N}$ $\left.80^{\circ} 37^{\prime} \mathrm{E}\right)$ (Kelaart, 1853, p. 4); Kekirawa ( $\left.8^{\circ} 02^{\prime} \mathrm{N} 80^{\circ} 36^{\prime} \mathrm{E}\right)$ (Hill, 1937b, pp. 219, 223, 226, 229, 237, 243); and Ranna (606'N 8052'E) (BNHS.5164; ZSI.12144; Ryley, 1914b, p. 704; Khajuria, 1956a, p. 200). W.W.A. Phillips (in litt., 26 December 1976), who knew the area fairly well, was sceptical of its occurrence at Ambawela, which he believed was within the range of $S$. vetulus monticola. He suspected a specimen labelling error.

Only when it is discovered whether the darker hands of southern Tamil Nadu specimens are subspecifically diagnostic or due to hybridization with Semnopithecus entellus or S. johnii can the boundary between $S$. p. priam and $S$. $p$. thersites be accurately established. S. $p$. thersites seems restricted in India mainly to southern Kerala and from there through south coastal Tamil Nadu to Adam's Bridge. A langur observed at $800 \mathrm{~m}$ on the Aliyar-Valparai road (ninth hairpin bend, c. $10^{0} 30^{\prime} \mathrm{N} 77^{\circ} 00^{\prime} \mathrm{E}$ ) in the Annamalai Hills, Tamil Nadu, had brownish-grey hands (personal observation, 11 March 2002). The langurs Balakrishnan and Easa (1986, p. 196) found exclusive to deciduous forest in the Parambikulam Wildlife Sanctuary (c. $\left.10^{\circ} 23^{\prime} \mathrm{N} 76^{\circ} 43^{\prime} \mathrm{E}\right)$, Kerala, are therefore probably also $S$. $p$. thersites. Kinloch (1923, p. 552) assessed the Nelliampathy Hills population as "decidedly rare, a...troop of not more than half a dozen monkeys may occasionally be found on the northern cliffs...seldom, if ever, found in evergreen forest". Although the colour reliability in photographs supplied by Rauf Ali (in litt.) precludes confident determination, the hand colour of langurs at Kalakad-Mundanthurai Tiger Reserve (c. $8^{\circ} 40^{\prime} \mathrm{N}$ $77^{\circ} 25^{\prime} \mathrm{E}$ ), Tamil Nadu, seems to vary from grey to almost white with black finger tips. In some of the apparently white-handed individuals there is a grey band across the knuckle or back of the hand. This leaves equivocal the subspecific identity of the langurs J.F. Oates (in litt., 9 May 1976) observed on the Tambraparni River, c. 200m, just below the Lower Papanasam Dam ( $\left.8^{\circ} 43^{\prime} \mathrm{N} 77^{0} 23^{\prime} \mathrm{E}\right)$; and Webb-Peploe (1947, p. 631) found fairly common on the rocky spurs which project onto the plains along the foothills near Dohnavur (c. $8^{0} 30^{\prime} \mathrm{N} 77^{\circ} 30^{\prime} \mathrm{E}$ ) and among the massive rock faces in the scrub jungle below the evergreen belt. About $8-10 \mathrm{~km}$ south of the Aramboli Pass, langurs reportedly travelled quite extensively from one forest patch to another, to which they kept more strictly than did Macaca radiata, but visited a Hindu temple precinct when its grove of tamarind trees was in fruit. The consensus was that they were "ash-coloured", black-pawed and crestless (Hill, 1937c, p. 210). The field notes with ZD.1923.1.20.1, collected on 7 October 1915 by R.S.N. Pillay (see Wroughton, 1921, p. 550; Pocock, 1928, pp. 496-497; 1931, pp. 55-59; Napier, 1985, p. 83), convinced Hill (1937c) that this specimen "of the priam...type" was probably collected in this same tamarind grove. His apparent inference that "hypoleucos and priam" are locally sympatric is unwarranted. Jerdon's (1867, p. 7) denial that $S$. priam extends to the Malabar Coast discredits his earlier claim (in Blyth, 1847b, p. $732 ; 1847$ c, p. 313 , footnote) for its occurrence near Tellicherry (= Thalassery, $11^{\circ} 45^{\prime} \mathrm{N} 75^{0} 32^{\prime} \mathrm{E}$ ). S. e. hypoleucos is unconfirmed south of the Nilgiri Hills.

A.F. Hutton (1950, p. 689) saw a few scattered Semnopithecus priam troops among the foothills, especially the rocky ones of the High Wavy Mountains $\left(9^{0} 32^{\prime} \mathrm{N} 77^{\circ} 25^{\prime} \mathrm{E}\right)$ but had no ecological explanation for their apparent absence in the Varushnaad Valley to the east. Above $1500 \mathrm{~m}$ he twice saw a troop of about twenty of an unfamiliar dorsally-grey monkey inhabiting an eponymous hill called "Samba-Manthi". They behaved like $S$. priam but like Macaca silenus were smaller (i.e. a head and body length of about $46-58 \mathrm{~cm}$, instead of $58-63 \mathrm{~cm}$ ). Their plaintive cheep-cheep recalled that of a lost domestic chick. The population seen by A.F. Hutton's (1950) friend at the northern end of the Annamalai Hills is probably a hybrid one of S. priam and S. johnii (personal observation, 11 March 2002). The black nape of the Samba-Manthi is anomalous as both species tend to be palest rather than darkest on the nape. It is conceivably an albinistic $S$. johnii or possibly the familiar langurs were $S$. $p$. priam while the unfamiliar ones were $S$. $p$. thersites.

\section{Pelage colour variation}

The holotype of Pithecus entellus priamellus is yellowish-white on the venter, tail-tip, back of the thigh to the anus (almost meeting across the proximal anterior edge of the thigh), and 
entire head, which has a slight greyish suffusion on the crown. The rest of the body, including the upper half of the flank, is pale brownish-grey. The hand, forearm, knee and first twothirds of the tail, except at its base, are a darker grey than the body. The knuckles are streaked with blackish-brown. The foot is yellowish-grey, pale brown at the base of the toes.

The darker of two individuals seen at $800 \mathrm{~m}$ on the Aliyar-Valparai road (c. $\left.10^{\circ} 30^{\prime} \mathrm{N} 77^{\circ} 00^{\prime} \mathrm{E}\right)$ had a dark grey tail and a pale brownishgrey dorsal colour which extended, marginally diluted, onto the back of the head. The thigh was similar, but almost black along the dorsal edge. It was paler between the dorsum and the callosities. The conical crest and the circum-facial area were yellowish-white. The second individual was generally paler and more yellow-tinged. Both had the last $300 \mathrm{~mm}$ or so of the tail pale yellow. The hand in the darker individual was brownish-grey, the paws resembling the limbs in colour. Of two individuals seen at the canal off the road at $400 \mathrm{~m}$ (pers. obs., 11 March 2002), one was pale with a conical crest. The other was darker, especially on the upper part of the back, and its head hair was more flattened with a small slender crest. A. Sharma (pers. comm.) suspects that, with age, the yellow of the chest intensifies to a russet orange, which he compares in colour to the paler part of the interior of a dry coconut husk.

\section{Malabar Langur}

\section{Semnopithecus (Semnopithecus) entellus hypoleucos Blyth, 1841} Semnopithecus johnii Martin, 1840

S[emnopithecus] dussumieri I. Geoffroy Saint-Hilaire, 1842

$\operatorname{Pr}[$ esbytis] Johnii Blyth, 1859

[Presbytis] leucopus Wroughton, 1912 (nomen nudum)

[Pithecus entellus] aeneas Pocock, 1928

Pithecus entellus iulus Pocock, 1928

\section{Etymology}

The noun phrase hypoleucos derives from the Greek preposition hupo, meaning "under", and the Greek adjective leukos, meaning "white", and refers to the white ventral pelage colour (Blyth, 1843b, p. 170). The masculine genitive singular proper noun dussumieri commemorates Jean-Jacques Dussumier (17921883), a Bordeaux merchant ship owner and travelling naturalist then on his fifth voyage on the brig, Buffon (Laissus, 1973, p. 391). The noun phrase leucopus derives from the Greek adjective leukos and the Greek noun pous, meaning "foot", but was used inadvertently (Wroughton, 1912b, p. 821). Bravest Trojan warrior after Hector, Aeneas sailed for Italy when Troy fell but was storm-driven to Tunisia where Zeus ordered him to desert Queen Dido of Carthage (Tunis) and return to Italy to become king of Laurentum. Originally named Iulus and often called Ascanius, Iulus founded the Italian city of Alba Longa (the site of the papal summer residence, Castel Gandolfo). His mother was either Priam's daughter Creusa or, according to another tradition Lavinia, a Latin princess whose marriage to his father Aeneas peacefully united the Latin and Trojan people. Being claimed as a family ancestor, his name is enshrined as July owing to the renaming in 44 BC of Caesar's birth month, Quintilis, the fifth of the Roman republican calendar. Aeneas and Iulus are masculine nominative singular proper nouns in apposition to the generic name. They are therefore not declined to agree in gender with that of the genus.

\section{Vernacular names}

Kannada: Mushya (Ryley, 1913c, p. 494); Musya, meaning whiskered monkey (Shortridge, in Wroughton, 1913, p. 32).

\section{Diagnosis}

Below average size and weight for Semnopithecus (sensu stricto), S. entellus hypoleucos is a crestless, black-pawed, yellowish-white subspecies with dark grey probably backwardlooped tail, suffused with brownish-grey on the back and limbs. It inhabits southwestern Karnataka, northern Kerala and possibly southwestern Maharashtra in southern India. Only its darker arm distinguishes it from $S$. e. achates with which it intergrades to the north and east. It probably intergrades to the south with $S$. priam thersites and possibly to the southeast with S. p. priam. Recognized by Pocock (1939) and by Napier (1985) but considered a junior synonym of $S$. hypoleucos by Groves (2001), [Pithecus e.] aeneas Pocock, 1928 from the Karnataka-Kerala border area is based on a population suffused with brown on the crown and back, and with blackish-brown on the limbs and tail, here presumed hybrid with S. johnii. Recognized by Pocock (1939) and by Napier (1985), Pithecus e. iulus Pocock, 1928 is here considered a junior synonym of $S$. e. hypoleucos. Groves (2001) considered it a junior synonym of $S$. dussumieri, in which he included populations here regarded as the southern ones of $S$. e. achates.

\section{Taxonomic status}

Apart from an apparently darker flank and probably browner back, the hybrid Semnopithecus johnii x S. priam specimen from the Nilgiri Hills figured in a colour photograph by Hohmann and Herzog (1985, fig. 1) resembles the holotype and paratype of [Pithecus entellus] aeneas Pocock, 1928 and the rest of the series from Makut and Wotekolli. The hybrid in their monochrome photograph (Hohmann and Herzog, 1985, fig. 6) is similar but the flank appears paler than in the Makut and Wotekolli series. The hybrid (partly obscured by a branch) occupying a tree with a fairly typical $S$. johnii in Hohmann and Herzog's (1985, fig. 7) second colour photograph resembles that in their monochrome photograph. Invisible in all three of these photographs, the venter in Nilgiri hybrids as indicated by its tone in the monochrome photograph of a $S . p$. priam specimen (Hohmann and Herzog, 1985, fig. 2) is probably much darker than in the Makut and Wotekolli series. The strong overall resemblance, however, although in the Nilgiris $S$. priam rather than $S$. entellus interbreeds with $S$. johnii, implies that $[P$. e.] aeneas is merely a hybrid population. The holotype of $S$. hypoleucos Blyth, 1841 appears intermediate between [P. e.] aeneas and populations represented by the type specimens of S. dussumieri Geoffroy, 1842 and of P. e. iulus Pocock, 1928 more distant from the geographic distribution of $S$. johnii. Interpreting these as diminishing degrees of gene pollution by $S$. johnii explains the anomalously close geographic proximity of these four Malabar langur putative subspecies recognized by Pocock $(1928 ; 1939)$. They are therefore here amalgamated into one subspecies. 


\section{Nomenclature}

A name remains available even if applied to a taxon later found to be a hybrid (ICZN, Article 17.2). The Malabar Langur was named in ignorance of this possible basis. Its available names therefore are covered by the provisions of the Code (Article 1.3.3) and may enter into homonymy. A species-group name of an animal later found to be a hybrid may not be used as the valid name for either of the parental species even if it predates all other available names (Article 23.8). Although [Pithecus entellus] aeneas probably represents a hybrid population, the seven examined Makut and Wotekolli specimens show limited individual variation in external morphology (see below). The five of them with skulls are all cranially referable to Semnopithecus (sensu stricto). No specimen of S. johnii was collected or reported in the vicinity, which is beyond Srimangala $\left(12^{\circ} 01^{\prime} \mathrm{N} 75^{\circ} 58^{\prime} \mathrm{E}\right)$ the suspected northern limit of $S$. johnii (Shortridge, in Ryley, 1913c, p. 492). These hybrids therefore are not the progeny of two individuals belonging to different taxa: the definition of a hybrid in the glossary of the fourth edition of the Code (1999). Instead they appear to represent a population heavily pervaded with $S$. johnii genes but only indirectly the product of contact between the two species. $S$. hypoleucos may represent a population more removed from direct contact with S. johnii. S. dussumieri and P. e. iulus represent populations still more remote but the presence of $S$. johnii genes cannot be excluded. On the contrary, they are likely to occur. If the trend in S. entellus is for northwards dispersal (see under "Conclusions"), S. johnii genes may be detectable in all populations adjacent to and north of the geographic distribution of $S$. johnii. All available names for the species may thus technically be based on hybrids. A new name would suffer the same deficiency. Unless recognition of the subspecies is abandoned as being based on characters of purely hybrid origin, there therefore seems no reasonable alternative to the use of $S$. hypoleucos as the earliest available name for the Malabar Langur. The names $S$. dussumieri or P. e. iulus cannot be objectively advocated as preferable.

\section{Type specimens}

The holotype of S[emnopithecus] hypoleucos Blyth, 1841 is an adult male skull and mounted skin donated by W. Coles in 1841 to the Museum of the Asiatic Society of Bengal (29A of Blyth, 1863, p. 12; and 13a of Anderson, 1881, p. 40), figured by Blyth (1847b, pl. 26, fig. 1) in a water-coloured lithograph and preserved at the Indian Museum, Kolkata as ZSI.11844. Khajuria (1956a, p. 200) reported detached hindquarters to the skin, lost arms and a damaged skull. In stating, "L'individu qui a servi de type à cette description est une femelle adulte", Geoffroy (1843a, p. 540; 1843b, p. 18) designated as lectotype of $S$. dussumieri Geoffroy, 1842 the adult female mounted skin with skull inside (Rode, 1938, p. 208, no. 11a), donated by J.-J. Dussumier to the Muséum National d'Histoire Naturelle, Paris, and figured by Geoffroy (1843a, pl. 30) in a coloured engraving. The juvenile female second "paratype" listed by Rode (1938, p. 208 , no. $11 \mathrm{~b}$ ) is ineligible as a paralectotype because Geoffroy (1843a, p. 540; 1843b, p. 19) specified that "Les deux individus que possède le Muséum, sont les seuls que je connaisse". The infant skin with no skull (Rode, 1938, p. 208, no. 11a) mounted with the lectotype is therefore the sole paralectotype. The lectotype was suckling the paralectotype when killed (Geoffroy, 1843a, p. 540; 1843b, p. 18).

The holotype of [Pithecus entellus] aeneas Pocock, 1928 is an adult male skull and round skin ZD.1914.11.18.23, collected (number 2299) on 12 January 1913. It and the paratype adult female skull and round skin ZD.1914.11.18.24, collected (number 2232) on 1 January 1913, both by G.C. Shortridge, are preserved at the Natural History Museum, London (Ryley, 1913c, p. 493; Pocock, 1928, pp. 492-493; Napier, 1985, p. 79). The holotype of P. e. iulus Pocock, 1928 is an adult female skull and round skin ZD.1914.11.18.7. It and the paratype adult male skull and round skin ZD.1914.11.18.6, both collected (numbers 1025 and 1026, respectively) on 4 May 1912 by G.C. Shortridge, are preserved at the Natural History Museum, London (Wroughton, 1913, p. 32; Pocock, 1928, pp. 490-491; Napier, 1985, p. 81). Pocock (1928, p. 490) cited the holotype of $P$. e. iulus as male, and probably intended the paratype to be the holotype. There being no other internal evidence for this, the specimen with the cited accession number is here accepted as the holotype.

\section{Type localities}

The holotype of $S[$ emnopithecus] hypoleucos was from a package "of skins... of Mammalia, procured in Travancore" (Blyth, 1841, p. 839). Travancore therefore, the approximate equivalent of southern Kerala, India, may not be its actual collecting locality but Blyth (1841, p. 840; 1843b, p. 170) learnt in Chennai (then Madras) that it was known as the Travancore monkey. At least three "well-educated people" informed Hill (1937c, p. 209) that langurs were extremely rare in Travancore, being found only in the extreme north-east of the state and at about $8-10 \mathrm{~km}$ south of the Aramboli Pass. If it was from Travancore, the holotype was probably from the north-east, but it may have originated from northern Kerala, between Kannur and Makut (see below). Further restriction or amendment of the type locality may prove impossible because a $S$. entellus x S. johnii hybrid such as the holotype (see above) could arise almost anywhere along the boundary between the two species.

The lectotype and paralectotype of S[emnopithecus] dussumieri were collected on the Malabar Coast, India (Geoffroy, 1842 , p. $719 ; 1843$ a, p. $540 ; 1843$ b, p. 17). The exact locality is uncertain. In a letter (here translated from the French) from "Bordeaux, 14 October 1827", Dussumier (1828, p. 378) announced "I bring a monkey, which unless M. Leschenault has pre-empted me I believe new: I have an adult female, her infant, an almost full-term foetus, and a complete skeleton". This is confirmed in the manuscript "Catalogue des animaux donnés au Muséum d'histoire Naturelle par M. Dussumier de Bordeaux. Séance du 13 9bre [=November] 1827", in which "Semnopithèque - espece nouv. voisin de l'Entelle. Malabar. 2 ind[ividuel]s" are first in the list of mammal skins, and "Semnopithèque à calotte Rousse. (foetus) du Malabar" is first among the alcohol-preserved mammals. (The foetus was apparently later to become one of the three colobine specimens whose gut morphology was examined by Duvernoy, 1835, p. 
2.). Dussumier (1828, p. 383 ) also had two live monkeys "(le Bonnet chinois), mâle et femelle". He was evidently knowledgeable on primates and the mother and infant are presumably the $S$. dussumieri lectotype and paralectotype. Geoffroy (1843a, p. 540; 1843b, p. 19; 1851, p. 13) and Rode (1938), however, recorded their receipt in 1830 and "Semnopithèque, espèce nouvelle voisin de l'entelle (adulte et jeune) - 2 indiv[iduels] de la cote de Malabar" is the first item in the manuscript "Catalogue des Mammifères et des oiseaux rapportés de l'Inde en 1830 et donnés au Muséum par M. Dussumier. Séance du 23 Novembre 1830". Although Dussumier collected two further skins of this subspecies (the second "paratype" and the Leiden specimen, see below), the chances are negligible that a mother and infant were the only dry skins he collected on two successive voyages. The implied loss of the first such pair is inexplicable. It is therefore inferred that the lectotype and paralectotype were inadvertently added to the 1830 list although they had been received in 1827 . They were evidently collected in late 1826 or early 1827 as the fifth voyage, ending in late summer 1827, rapidly followed the fourth, completed in the spring of 1826 (Laissus, 1973, p. 391). Dussumier (1828, p. 378) specified that business obligations prevented him from leaving the coast to visit the Ghats. He had several of "another triggerfish (Triacanthe) caught in Cananor [= Kannur] harbour" (p. 382). An English resident sent him freshwater fish from Mysore (p. 380). He also mentioned two live "anis" (coucals or koels) from Cape Comorin (p. 383). Jerdon $(1867$, p. 8) confirmed the (abundant) presence of $S$. entellus at Tellicherry (= Thalassery, $\left.11^{\circ} 45^{\prime} \mathrm{N} 75^{\circ} 32^{\prime} \mathrm{E}\right)$. The type locality of $S$. dussumieri is here provisionally restricted to Kannur, $11^{0} 59^{\prime} \mathrm{N}$ $75^{\circ} 32^{\prime} \mathrm{E}$, Kerala, India.

The holotype of [Pithecus entellus] aeneas was collected at Makut (= Makutta, c. $\left.12^{\circ} 05^{\prime} \mathrm{N} 75^{\circ} 45^{\prime} \mathrm{E}\right), 250 \mathrm{ft}(80 \mathrm{~m})$, and the paratype at Wotekolli $\left(12^{\circ} 08^{\prime} \mathrm{N} 75^{\circ} 47^{\prime} \mathrm{E}\right.$, see Fooden, 1981, p. 45, ?=Wattekuli), 2000ft $(600 \mathrm{~m}), 13 \mathrm{~km}$ further north. Both localities are in South Coorg (= Kodagu), Karnataka, India (Ryley, 1913c, pp. 489, 493; Pocock, 1928, pp. 492-493; Napier, 1985, p. 79). According to their original labels, the holotype and paratype of $P$. e. iulus were both collected at Jog (Falls, $14^{0} 14^{\prime} \mathrm{N} 74^{0} 50^{\prime} \mathrm{E}$ ), 1300ft (400m), Kerala, India (Pocock, 1928, pp. 490-491; Napier, 1985, p. 81), not "Hulekal, N. Kanara" as reported by Wroughton (1913, p. 32).

\section{Geographic distribution}

Shortridge (in Wroughton, 1913, p. 32) noted considerable variation in size, weight and amount of black on the arm and paws in the adult langurs abundant in Kanara (Karnataka). Those from Gersoppa and Jog were especially dark. Two Samasgi (c. $14^{\circ} 40^{\prime} \mathrm{N} 75^{\circ} 05^{\prime} \mathrm{E}$ ) specimens are referable to Semnopithecus entellus hypoleucos (BNHS.5177 and evidently ZSI.12140, see Khajuria, 1956a, p. 199), two are intermediate (ZD.1914.11.18.12; BNHS.5178), and two referable to $S$. e. achates (ZD.1914.11.18.10-11). Specimens from Devikop $\left(15^{\circ} 08^{\prime} \mathrm{N}\right.$ $\left.74^{0} 56^{\prime} \mathrm{E}\right)$ and all but one (BNHS.5181) of five specimens from Karwar $\left(14^{0} 48^{\prime} \mathrm{N} 74^{\circ} 08^{\prime} \mathrm{E}\right)$ are referable to $S$. e. achates, indicating that $S$. e. hypoleucos ranges north at least to $15^{\circ} 00^{\prime} \mathrm{N} 74^{\circ} 40^{\prime} \mathrm{E}$. Jerdon $(1867$, p. 8) believed it restricted to the Malabar forests, gardens and cultivated coastal woodland from there to Cape Comorin but the only corroboration is his report (in Blyth, 1843b, p. 170) of abundant small troops in the dense forest "at the base of the Neilgherries in Malabar, Travancore, etc.". The distribution of $S$. e. hypoleucos is here provisionally extended to Helwak $\left(17^{\circ} 22^{\prime} \mathrm{N} 73^{\circ} 44^{\prime} \mathrm{E}\right)$ and Pune $\left(18^{\circ} 32^{\prime} \mathrm{N} 73^{\circ} 52^{\prime} \mathrm{E}\right)$ to account for the presence there of unusually dark $S$. e. achates specimens. It may therefore be the langur Tiwari et al. (1971, p. 378) encountered in the forest around Sinhagarh (= Sinhgarh, $18^{\circ} 22^{\prime} \mathrm{N} 73^{\circ} 45^{\prime} \mathrm{E}$ ) Fort. The ones they also recorded common on the road from Mahabaleshwar to Wai (c. $17^{0} 55^{\prime} \mathrm{N} 73^{\circ} 47^{\prime} \mathrm{E}$ ), and those Dixon (1894) reported keen on the fruit of Strychnos nuxvomica at Ratnagiri $\left(16^{0} 59^{\prime} \mathrm{N} 73^{\circ} 18^{\prime} \mathrm{E}\right)$ and Sawantwady (= Savantvadi, $15^{\circ} 54^{\prime} \mathrm{N} 73^{\circ} 49^{\prime} \mathrm{E}$, Maharashtra) are possibly intermediate with S. e. achates. Fletcher (1911, p. 427) found it common on the coast but rare in the Ghats forests, never ascending above $300 \mathrm{~m}$ and therefore barely classifiable as a Wyanad monkey. Jerdon (1867) agreed on its absence from the Wyanad Plateau (c. $11^{\circ} 29^{\prime} \mathrm{N} 76^{\circ} 24^{\prime} \mathrm{E}$ ) and never saw it above $400 \mathrm{~m}$ on the various passes he had crossed; Shortridge (in Ryley, 1913c, p. 494) reported S. e. hypoleucos fairly plentiful on the slopes to the foot of the Ghats around Wotekolli and Makut but replaced by S. e. achates to the east of the Brahmagiri Hills at Nagarhole (c. $12^{\circ} 00^{\prime} \mathrm{N} 76^{\circ} 05^{\prime} \mathrm{E}$ ), the type locality of [Pithecus e.] elissa Pocock, 1928. Colobine species appeared absent in North Kodagu, although evergreen forest occurred at all three localities where mammals were collected: Haleri $\left(12^{\circ} 27^{\prime} \mathrm{N} 75^{\circ} 43^{\prime} \mathrm{E}\right)$, Jambur $\left(12^{\circ} 31^{\prime} \mathrm{N} 75^{\circ} 48^{\prime} \mathrm{E}\right)$ and Mercara (= Madikeri, $\left.12^{0} 25^{\prime} \mathrm{N} 75^{\circ} 44^{\prime} \mathrm{E}\right)$ (Ryley, 1913c, p. 489).

\section{Pelage colour variation}

Martin (1840, p. 489) described the head, whiskers and conspicuous beard of the $S[$ emnopithecus] dussumieri lectotype as a drab "straw-yellow" (termed "fawn" by Geoffroy, 1842, p. $719 ; 1843$ b, p. 18), which gradually merges into the "fuliginousgrey" ("greyish brown" of Geoffroy) of the back. This becomes darker on the shoulder and thigh, and almost black on the arm and leg. The paws, face, long eyebrows, the hairs continuing from there along the sides of the cheek, and scattered hairs on the upper lip are black (Geoffroy [1843b, p. 18] also includes the forearm as black.). The tail is dark brown, much paler on the last third. The venter and inside of the brachium and thigh are a "dusky straw-colour". The paws, pinnal hairs and those along the facial margin, except in the centre of the chin in the juvenile female specimen 1 listed by Schlegel (1876, p. 63), are blackish. The tail and dorsal aspect of the rest of the limbs are brownish, the forearm being darker than the shank. The head is yellowish, sparsely intermingled with blackish hair on the cheek from eye level to the pinnal tragus. The rest of the body is yellowishwhite, darker along the dorsal midline, possibly through dust. Jerdon $(1867$, p. 8) described the head as "fulvous" (reddishyellow), the venter yellowish-white and the limbs and tail dark brown, almost black, with considerable colour intensity variation, especially in the blackness of the limbs and tail.

In specimens from Jog, the crestless head is whitish-yellow behind the long black eyebrows. Dark cheek hairs, fringing the black face to the chin, extend back to the black-haired ears. 
The brachium, shank and a fairly broad band along the centre of the back are brownish-grey. In the paratype of Pithecus entellus iulus, the mid-dorsal colour is more blackish than in the holotype, which is intermediate between it and adult female skull and round skin ZD.1937.5.26.6, collected (number 1067) in 1912 by G.C. Shortridge. The flank varies from yellowish-white in ZD.1937.5.26.6 to greyish-white in the holotype, with the paratype being intermediate. The paws are brownish-black and the shank slightly darker than the back. The forearm darkens from blackish-brown at the long-haired elbow to brownish-black at the wrist. The tail is brown with a variable length of blond at its tip. In the adult holotype and paratype the blond extends along the last third of the tail, while in the juvenile ZD.1937.5.26.6 it is almost restricted to the tip. In the paratype, hairs with blond roots extend into the mid third of the tail, which is superficially suffused with blackish, strongly in the paratype, minimally in the holotype and to an intermediate extent in the juvenile. The venter including the rather sparsely-haired inner limb surface is yellowish-white with blond extending onto the back of the thigh above the callosities. The chin and more so the cheek grade to pale orange, which covers most of the chest in the holotype.

Subadult female round skin BNHS.5177 and juvenile male round skin BNHS. 5178 from Samasgi are both crestless. BNHS.5177 is essentially a dark-forearmed Semnopithecus entellus achates with an orange yellow head and quite blackish cheeks. In BNHS.5178 the arm is only marginally darker than in $S$. e. achates. The paws are brownish-black with some pale brownish on the fingers. The dorsal band is pale yellowish-brown, more yellow on the occiput, but slightly darker on the lateral part of the nape. The paws and eyebrows of male round skin, presumed adult, BNHS.5181, collected by C. McCann in September 1940 at Karwar, are blackish. The limbs are pale greyish-brown, intermingled with yellow hair and increasingly blackened towards the wrist. The thigh, ankle, venter, flank and most of head are orange yellow. The cheek is orange black. Some blackish hair are intermingled with the orange yellow ones between the pinnae. The tail is dark yellowish-brown, its last $300 \mathrm{~mm}$ pale yellow. The dorsal band is pale brown, becoming darker (pure brown) in the interscapular region. The male round skin BNHS.5182, with the same data as BNHS.5181 but date of collection specified as 8 September 1940, is fragmented but seems paler and more classifiable than BNHS.5181 as a dark $S$. e. achates. Less than the last $200 \mathrm{~mm}$ of the dark tail is yellowish. There is apparently no blackish on the occiput. The paws conform in colour with the limbs, but may not belong with the other fragments.

Blyth (1841, p. 839) described the back, shoulder, outside of the brachium and thigh of the holotype of S[emnopithecus] hypoleucos as a deep, somewhat dusky (presumably greyish) brown, tinged with "chocolate". The colour was hard to verbalize, but Blyth (1843b, p. 170) specified it as a darker version of "the duskyish chocolat-au-lait" lumbar colour of $S$. e. entellus, darkest in the middle of the back and between the shoulders, and considerably diluting towards the rump. It grades into white on the flank, venter, inside of the brachium and thigh, but Blyth (1843b, p. 170) conceded the venter is "sufficiently tinged with straw-yellow" to somewhat repudiate the name he chose for the species. The face, tail, eyebrow, a few cheek and lip hairs and the rest of the limbs are black, intermingled with white on the inside of the forearm and leg. The head and whiskers are brownish-white, somewhat darker on the crown (Blyth, 1841). Blyth (1844b, p. 470) described the head as "of a dirty pale straw-colour". Anderson (1879, pp. 20$21 ; 1881$, p. 40) described the tail as brownish towards its tip, "the front of the tibia" pale brownish and the head and venter yellow, especially bright on the chest and abdomen.

Pocock (1928, p. 492) diagnosed [Pithecus entellus] aeneas as a larger and darker version of Semnopithecus e. hypoleucos. The darker crown grades anteriorly to pale orange, and departs from the shoulder colour less than in Jog specimens. The paws are black. The forearm, elbow, shank, knee, front of the thigh, front of the shoulder and first half of the tail are brownishblack. The forearm and shank are ventrally more brownish. Most of the back, brachium, thigh and second half of the tail is usually brown. The tail fades almost to pale yellow at its tip. The throat, groin, perineum, flank and ventral side of the brachium are whitish-yellow, suffused with grey on the flank. The cheek and rest of the venter are pale orange. Juvenile males ZD.1979.529-530 are ventrally less orange than are the adults. ZD.1914.11.18.24-25 are most orange on the lower lateral parts of the abdomen. The paratype (ZD.1914.11.18.24) has a distinct orange patch between the nipples. Blackish hairs variably spread from the facial margin towards the ear, most markedly in the holotype; to a moderate extent in ZD.1979.529, collected (number 2213) on 27 December 1912 at Wotekolli; and negligibly in ZD.1914.11.18.24. It and ZD.1979.529-530 are nuchally paler than on the shoulder, especially in ZD.1979.530, collected (number 2234) on 1 January 1913 at Wotekolli, whose nape is pale greyish-yellow. Their crowns are only slightly paler than in the holotype and in subadult male ZD.1914.11.18.25, collected (number 2244) on 2 January 1913 at Wotekolli. Less than usual of the flank and virtually only the upper part of the back in ZD.1979.529 is brown. Its forearm and that of ZD.1914.11.18.25 is ventrally more brownish, less orange but barely paler than is the brachium. In this respect, ZD.1979.530 is intermediate between them and the holotype. ZD.1914.11.18.24 has merely some yellowish-white hairs intermingled with the brown ventral hair of the forearm. In ZD.1914.11.18.25, the second half of the tail is wholly tinged with pale yellow, but coat damage reveals more of the hair root colour. With the possible exception of ZD.1979.529, similar pale root colour appears absent in other specimens.

Adult female skull and round skin BNHS.5147, collected (number 2233) on 1 January 1913 at Wotekolli, most resembles the holotype of [Pithecus entellus] aeneas and ZD.1914.11.18.25 in becoming pale yellowish-orange on the venter, flank and most of the head, and ZD.1914.11.18.25 in its limb and tail colour. The dark brown posterior of the thigh, however, is sprinkled with pale yellowish-brown hairs and the last third of the dark brown tail is brownish-yellow. The reduction of the dorsal brown largely to a triangular area whose acute apex almost 
reaches the tail, leaving the rest of the back a pale yellowishbrown, most resembles ZD.1979.529. The near coalescence of blackish hairs across the deep orange side whiskers from the facial margin to the pale blackish-yellow of the back of the head most resembles ZD.1979.529-530. The overall cheek colour most resembles that of the holotype. Adult male skull and round skin BNHS.5148, collected (number 2301) on 12 January 1913 at Makut, resembles BNHS.5147 but is darker on the leg, which like that of the holotype is virtually devoid of yellow, especially on the shank. The shoulder is more blackish-brown and less tinged with pale yellow. Again like the holotype, there is less black on the back of the head, which is dark greyish-yellow, more orange towards the ears. Like ZD.1914.11.18.24, the venter is more orange and like it and the holotype, the trunk is dorsally more uniformly brown. There is less black around the lower margin of the face. ZD.1979.529 has the fewest black hair fringing the lower lip. These hair are long enough to span the chin in ZD.1914.11.18.25 but shorter in the holotype and in ZD.1914.11.18.24. The black hair pigment seems deepest in the holotype and in ZD.1914.11.18.25.

\section{Plains Langur}

Semnopithecus (Semnopithecus) entellus achates (Pocock, 1928)

[?] Cercopithecus albo-cinereus Desmarest, 1822

[Pithecus entellus] elissa Pocock, 1928

Semnopithecus dussumieri Groves, 2001

\section{Etymology}

The noun phrase albo-cinereus derives from the Latin adjective albus, meaning "white", and the Latin adjective cinereus, meaning "ashy", and refers to the grey dorsal and white ventral pelage colour (Desmarest, 1822). In the Aeneid, Virgil epitomized Achates as the faithful friend and travelling companion of Aeneas after the escape from Troy. Elissa or Dido was the daughter of the king of Tyre (now Tyr in Lebanon). When her brother Pygmalion murdered her husband Sychaeus, she fled and according to mythology founded Carthage (Tunis). To evade marriage to Iarbas, king of Numidia, she stabbed herself on a funeral pyre. Virgil anachronistically attributed her death to unrequited love for Aeneas who predeceased her by about three centuries. Achates is a masculine and Elissa a feminine nominative singular proper noun in apposition to the generic name. They are therefore not declined to agree in gender with that of the genus.

\section{Vernacular names}

Kannada: Adavi-koti; Kari-kóti; Mushya (Wroughton, 1912d, p. 1175), the latter meaning whiskered monkey (Shortridge, in Wroughton, 1913, p. 32). Marwari: Bandero. Hindi: Langur (Prakash, 1956, p. 3). Haran Shikaris: Kari-mangyá. Waddars: Karimikkamungyá; Yerpa-moti-koti. Dekhani: Langúr. Marathi: Maka; Wánar; Wánga (Wroughton, 1912d, p. 1175). Vandra (Ryley, 1913b, p. 472). Wandir (ZD.1951.610).

\section{Diagnosis}

About average size and weight for Semnopithecus (sensu stricto), the normally crestless $S$. entellus achates holds its tail backwards in western Andhra Pradesh, southern Karnataka and western Maharashtra, and forwards in the rest of its range in northern Chhatisgarh, Gujarat, Madhya Pradesh, southeastern Rajasthan and probably Uttar Pradesh in central India. Probably a junior synonym of Cercopithecus albo-cinereus Desmarest, 1822 , it is a black-pawed, yellowish-white subspecies, suffused with brownish-grey on the back, tail and limbs. Only its paler arm distinguishes it from S. e. hypoleucos with which it intergrades to the south-west. It intergrades to the south-east with $S$. p. priam, and to the east in turn with both $S$. e. entellus and $S$. e. anchises. Intergradation to the north with $S$. e. hector requires confirmation. Recognized by Pocock (1939) and by Napier (1985), [Pithecus e.] elissa Pocock, 1928 is here considered a (crested) junior synonym. Groves (2001) considered it and $S$. e. achates junior synonyms of $S$. dussumieri. He and Napier (1985) followed Pocock (1939) in referring the northern section of the distribution of $S$. e. achates to S. e. entellus.

\section{Nomenclature}

According to Geoffroy (1831, pp. 49-50) and Martin (1840, p. 469), Cercopithecus albo-cinereus Desmarest, 1822 describes none of the Javan or Sumatran cercopithecids received by the Muséum National d'Histoire Naturelle, Paris from either PierreMédard Diard or Alfred Duvaucel. Geoffroy (1843b, p. 22; 1851a, p. 12) believed the description written from memory or inadequate notes and inapplicable to any monkey at the museum in 1822. Blyth (1843b, p. 175) initially considered it a possible senior synonym of Semnopithecus pileatus Blyth, 1843 but Blyth (1847b, p. 733) later followed Cantor (1846, p. 174) in employing it as a senior synonym of Presbytis siamensis (Müller \& Schlegel, 1841). To Schlegel (1876, p. 38) this determination was definitive, as P. siamensis is the only dorsally grey, ventrally white Sumatran species with a brown tail and black paws. Diard and Duvaucel's putative collecting localities, however, are unreliable (Brandon-Jones, 1999). Restricted to the description alone, Desmarest (1822) was apparently describing an Indian langur. This is suggested by its long stiff eyebrows, its large angular black ears, the dorsal blackish of the paws and its grey mid dorsal colour which darkens towards the rump. The adult male S. entellus specimen from "Bengale", MNHN.1997.2141, listed by Geoffroy (1851a, p. 13) as having been sent by Duvaucel in 1822, differs from Desmarest's (1822) description in having few black bristles laterally projecting from the side of the face, and neither the ventral nor the crown hairs are sparse. The general colour is pale orange, more brown on the forearm, knee and central back, and brownish-grey on the last threequarters of the tail. It conforms in pelage colour with other specimens from the Bengal vicinity.

The current absence of any specimen at the Muséum National d'Histoire Naturelle, Paris, identifiable as the holotype of Cercopithecus albo-cinereus does not invalidate the name. It satisfies all the criteria of availability. Bonhote (1901, p. 872), Robinson (1905, p. 101), Thomas and Wroughton (1909, p. 106) and Dammerman (1926, p. 316) continued to employ it as a senior synonym of Presbytis siamensis, and Schneider (1905, p. 69) as a senior synonym of $P$. femoralis, so it cannot be suppressed as a name unused since 1899 . In attempting to identify the 
holotype, Geoffroy (1843b; 1851a) might have ignored monkeys at the museum in 1822 other than from the purported type locality. Roland Seitre (pers. comm., 1994) reported that in the late nineteenth century some specimens were transferred from Paris to the Museum at Elbeuf, Normandy. The "Entelle vieux" figured by Cuvier (1825a) was based on an illustration sent by Duvaucel. Although Desmarest (1822) claimed that C. albocinereus was a species new to the collection, he might have reiterated the information drafted for other descriptions, forgetting that this one was based on an illustration. Such an oversight would not invalidate the name, nor would its being based on an illustration, nor its erroneous type locality. However, Desmarest's (1822) detailed description of the hair density on the face, cheek, crown, ear, chin and venter would be unobtainable from an illustration.

The holotype of Pithecus entellus achates Pocock, 1928 fits Desmarest's (1822) description of Cercopithecus albo-cinereus, except that the crown hairs are not sparse. The flank is more greyish-white than pale grey. The darker (brownish) grey mid dorsal band, although palest, with an orange tinge, at its commencement behind the nape, is darkest midway down the back and does not expand in width towards the rump. The venter is yellowish-white and almost naked. The hair between the nipples and the abdomen is sparser than in central and northeastern Indian specimens. The forearm is darker grey than the rest of the limbs but the shank is darker only than the rear of the thigh. The hand is greyish-black, the foot brownishblack. The tail is grey-brown, but distally whitish-yellow.

Pithecus entellus achates Pocock, 1928 (p. 489) was published simultaneously with page precedence over $[P . e$. $]$ elissa Pocock, 1928 (p. 493). Their holotypes are both arguably intermediate, the former with Semnopithecus e. hypoleucos and the latter with $S$. p. priam. The latter's resemblance is closer and its type locality is nearer the range limit for the subspecies. As the First Reviser (ICZN, Article 24) the author here awards priority to $S$. e. achates.

\section{Type specimens}

The holotype of Cercopithecus albo-cinereus Desmarest, 1822 remains untraced but may have been transferred from Paris to the museum at Elbeuf, Normandy or some other museum. The holotype of Pithecus entellus achates Pocock, 1928 is an adult male skull and round skin ZD.1914.11.18.1, collected (number 714) on 23 February 1912. It and eleven paratypes, all collected by G.C. Shortridge, are preserved at the Natural History Museum, London. They comprise adult male skulls and round skins ZD.1913.7.5.4, collected (number 185) on 26 November 1911; ZD.1914.11.18.2, collected (number 511) on 18 January 1912; ZD.1914.11.18.4, collected (number 145) on 22 November 1911; ZD.1914.11.18.8, collected (number 1673) on 16 August 1912; ZD.1914.11.18.10, collected (number 748) on 12 March 1912; and ZD.1914.11.18.11, collected (number 781) on 19 March 1912; and adult female skulls and round skins ZD.1913.7.5.3, collected (number 47) on 2 November 1911; ZD.1914.11.18.3, collected (number 512) on 18 January 1912; ZD.1914.11.18.5, collected (number 186) on 26 November 1911; ZD.1914.11.18.9, collected (number 1572) on 4 August 1912; and ZD.1914.11.18.12, collected (number 744) on 12 March 1912 (Wroughton, 1912d, p. 1176; 1913, p. 32; Wroughton \& Ryley, 1913b, p. 60; Pocock, 1928, pp. 489-490; Napier, 1985, p. 78-79). Pocock (1928, p. 489) recorded the field measurements of adult female paratype skull BNHS.6258, collected (number 715) on 23 February 1912 and preserved at the Bombay Natural History Society, Mumbai, but its skin is unaccounted for. Only two adults (Wroughton, 1913, p. 32), not three (Pocock, 1928, p. 490) were collected at Potoli. Perhaps all three especially noted paratypes were from another locality. The holotype of $[P . e$. $]$ elissa Pocock, 1928 is an adult female skull and round skin ZD.1914.11.18.16, collected (number 2556) on 16 February 1913. It and two paratypes, all collected by G.C. Shortridge, are preserved at the Natural History Museum, London. The paratypes are adult male skull and round skin ZD.1914.11.18.15, collected (number 2568) on 17 February 1913, and adult female skull and round skin ZD.1914.11.18.17, collected (number 2564) on 16 February 1913 (Ryley, 1913c, p. 494; Pocock, 1928, pp. 493-494; Napier, 1985, p. 80).

\section{Type localities}

Stepson of George Cuvier, Duvaucel left France in December 1817 and joined Diard in Kolkata, India in May 1818. They established a base at Chandernagore (= Chandannagar, $22^{\circ} 51^{\prime} \mathrm{N}$ $88^{\circ} 21^{\prime} \mathrm{E}$ ) but in December accompanied Thomas Stamford Raffles to Singapore and Sumatra. When Raffles curtailed their contract Diard moved to Jakarta (Indonesia) while in 1820 Duvaucel reestablished a base at Chandannagar (de Lacaze, 1856, columns 534-536). Duvaucel's attempts (in Cuvier, 1825a) to shoot one of seven or eight Semnopithecus entellus which visited his Chandannagar garden for fruit during a month and more in late winter were frustrated by pious Brahmans who repelled them with tom-toms. Duvaucel did manage to shoot a langur in Guptipara $\left(23^{\circ} 13^{\prime} \mathrm{N} 88^{\circ} 25^{\prime} \mathrm{E}\right.$, not Goalpara, $26^{\circ} 10^{\prime} \mathrm{N} 90^{\circ} 40^{\prime} \mathrm{E}$, Meghalaya, as Ogilby, 1838, wrongly surmised). Though dying, this female transferred her infant from her back to a branch. His professed remorse (in Cuvier, 1825a) at extinguishing such altruism did not, however, deter Duvaucel from collecting others: MNHN.1997.2141 is a male. The Brahman prediction of fatal consequences within a year of committing such sacrilege proved about a year out. Duvaucel died at Chennai aged 31 in late August 1824 (de Lacaze, 1856) of dysentery complicated by injuries inflicted by a charging Indian rhinoceros (Cuvier, 1825b). If Desmarest's (1822) description is reliable, it perhaps indicates that the holotype of Cercopithecus albo-cinereus was collected or observed during Duvaucel's visit to Varanasi $\left(25^{\circ} 20^{\prime} \mathrm{N} 83^{\circ} 00^{\prime} \mathrm{E}\right.$, Uttar Pradesh) in 1822. He reached Kathmandu, Nepal, in 1823 and spent the rest of his time from 22 July 1821 exploring Upper Bengal as far as Chhatak and Sylhet in northeast Bangladesh (de Lacaze, 1856, columns 536-539).

The holotype of Pithecus entellus achates and paratype BNHS.6258 were both collected at Hawsbhavi (= Havasbhavi,

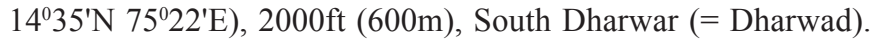
Paratype ZD.1913.7.5.3 was collected at Alnavar $\left(15^{\circ} 26^{\prime} \mathrm{N}\right.$ 74044'E), Dharwar Dist[rict]; paratypes ZD.1913.7.5.4 and ZD.1914.11.18.4-5 at Devikop (15 $\left.08^{\prime} \mathrm{N} 74^{0} 56^{\prime} \mathrm{E}\right), 2000 \mathrm{ft}(600 \mathrm{~m})$; 
and paratypes ZD.1914.11.18.10-12 at Samasgi (c. $14^{\circ} 40^{\prime} \mathrm{N}$ $\left.75^{\circ} 05^{\prime} \mathrm{E}\right)$, Kanara border, $2000 \mathrm{ft}(600 \mathrm{~m})$. These four localities are in the then S. Mahratta (= Maratha). Paratypes ZD.1914.11.18.23 were collected at Potoli $\left(15^{\circ} 11^{\prime} \mathrm{N} 74^{0} 33^{\prime} \mathrm{E}\right), 1800 \mathrm{ft}(550 \mathrm{~m})$, southeast of Supa, 6miles south of Kalinadi River, North Canara (= Kanara); and paratypes ZD.1914.11.18.8-9 at Vijayanagar $\left(15^{\circ} 19^{\prime} \mathrm{N} 76^{0} 28^{\prime} \mathrm{E}\right)$, Bellary, 1500ft (450m) (Wroughton, 1912d, p. 1176; 1913, p. 32; Wroughton \& Ryley, 1913b, p. 60; Pocock, 1928, pp. 489-490; Napier, 1985, pp. 78-79). The holotype and paratype localities are all in Karnataka. The holotype and paratypes of $[P$. e. $]$ elissa were collected at Nagarhole (c. $12^{\circ} 00^{\prime} \mathrm{N}$ $76^{0} 05^{\prime} \mathrm{E}$, Karnataka), India (Ryley, 1913c, p. 494; Pocock, 1928, pp. 493-494; Napier, 1985, p. 80).

\section{Geographic distribution}

On 17 January 1879, J. Cockburn donated to the Indian Museum, Kolkata a "very large" adult male Semnopithecus entellus skeleton, ZSI.11829 from Allahabad $\left(25^{\circ} 27^{\prime} \mathrm{N} 81^{\circ} 51^{\prime} \mathrm{E}\right)$ (Anderson, 1881, p. 37, 11z; Khajuria, 1956a, p. 197). A straight line from there to a little below Boondee (= Bundi, $25^{\circ} 27^{\prime} \mathrm{N} 75^{\circ} 39^{\prime} \mathrm{E}$ ) represented to T. Hutton $(1868$, p. 947) the northern limit of its natural distribution. T. Hutton (1868, pp. 948-951) considered the Himalayan Langur a separate species (S. schistaceus). A few kilometers above Neemuch (= Nimach, $\left.24^{0} 28^{\prime} \mathrm{N} 74^{0} 52^{\prime} \mathrm{E}\right), S$. entellus formerly occupied a grove around some Hindu temples (c. $\left.25^{\circ} 10^{\prime} \mathrm{N} 75^{\circ} 19^{\prime} \mathrm{E}\right)$. Having no reports of its local presence elsewhere, T. Hutton (1868, p. 947) suspected it had been introduced from Muttra (= Mathura, 27030'N $77^{\circ} 41^{\prime} \mathrm{E}$ ) or Bindrabun (= Brindavan, $27^{0} 35^{\prime} \mathrm{N} 77^{\circ} 42^{\prime} \mathrm{E}$ ). That these too were artificial populations was indicated by its abundance at Brindavan in 1836 on his spring visit and its subsequent absence there (Johnson, 1839). Turner (1800, p. 147) saw S. entellus at Mathura. Reintroduced in 1843, it disappeared within two years and in 1867 was completely absent. Between 1956 to 1960, however, Prakash (1962, p. 83) occasionally observed it there and at Bharatpur $\left(27^{\circ} 13^{\prime} \mathrm{N} 77^{\circ} 29^{\prime} \mathrm{E}\right)$. Itinerant showmen informed T. Hutton (1868, p. 948) of small troops between Delhi $\left(28^{\circ} 40^{\prime} \mathrm{N}\right.$ $\left.77^{\circ} 13^{\prime} \mathrm{E}\right)$ and Meerut $\left(28^{\circ} 59^{\prime} \mathrm{N} 77^{\circ} 42^{\prime} \mathrm{E}\right)$ and of a few at Agra $\left(27^{\circ} 11^{\prime} \mathrm{N} 78^{\circ} 01^{\prime} \mathrm{E}\right)$ but freely admitted that $S$. entellus had recently been introduced there by fakirs and devotees. Several Indians assured T. Hutton (1868) that in Oudh (= Avadh, in central Uttar Pradesh from about $80^{\circ}$ to $83^{\circ} \mathrm{E}$ ) it occurs only where fakirs introduce it near temples. It was such a local rarity that as a boy one of his informants had witnessed crowds revering a langur said to have accidentally crossed the Ganges by boat or on an uprooted tree. Oppenheimer (1977, p. 479) identified the langurs Jay (1965, pp. 199-201) studied at Kaukori (= Kakori, $\left.26^{0} 54^{\prime} \mathrm{N} 80^{\circ} 48^{\prime} \mathrm{E}\right)$ in Avadh as "P[resbytis $]$ e. schistaceus" (= S. e. hector, see below). Whereas Sugiyama (in Oppenheimer, 1977 , p. 478), presumably referring to the populations Sugiyama $(1965$, p. $14 ; 1967$, p. 224$)$ briefly surveyed at Nagpur $\left(21^{0} 10^{\prime} \mathrm{N}\right.$ $70^{\circ} 05^{\prime} \mathrm{E}$, Maharashtra) and Raipur $\left(21^{\circ} 16^{\prime} \mathrm{N} 81^{\circ} 42^{\prime} \mathrm{E}\right.$, Chhattisgarh), thought they most resembled " $P$. e. entellus". Their geographic situations indicate the Nagpur and Raipur populations are more probably S. e. achates.

T. Hutton (1868, p. 946) reported Semnopithecus entellus "entirely restricted by nature to the right or southern banks of the Rivers Ganges and Jumna" (= Yamuna). This was corroborated by J. Cockburn (in Sterndale, 1884, p. 16, footnote): "The entellus monkey is...not found on the north bank of the Ganges, and attempts at its introduction have repeatedly failed". Jacquemont (1841) may be the source of the contradictory holograph footnote: "I hear that it abounds on the left bank of the main stream of the Ganges", inserted by Blyth (1847b, p. 732 ) in J.E. Gray's reprint. However, the huge langur aggregation in January 1830 , according to Jacquemont $(1841$, p. 380) of nursing females only, was at Hanmanna (= Hanumana, $24^{\circ} 47^{\prime} \mathrm{N}$ $82^{\circ} 06^{\prime} \mathrm{E}$ ) south of the Ganges. The several langur families peaceably inhabiting a Hindu temple at Varanasi might have been introduced. Dalgliesh (1903, p. 94) reported S. entellus uncommon in the Darbhanga District, Bihar, but one which for some years periodically visited the Dalsingh Serai (= Dalsingh Sarai, $25^{\circ} 40^{\prime} \mathrm{N} 85^{\circ} 50^{\prime} \mathrm{E}$ ) Factory was almost tame enough to accept food from the hand. Rather than S. e. hector, the Kakori and Varanasi langurs are probably $S$. e. achates, and the Darbhanga ones S. e. entellus.

Its apparent absence from the Punjab convinced T. Hutton (1868, p. 948) that the western range limit of Semnopithecus entellus is at about longitude $75^{\circ} \mathrm{E}$. It has subsequently been found in Kathiawar (Ryley, 1913b, p. 472; Rahaman, 1974) where Macaca mulatta is absent (Ryley, 1913b, p. 470). The most westerly known $S$. e. achates locality there is Talala $\left(21^{\circ} 02^{\prime} \mathrm{N}\right.$ $\left.70^{\circ} 32^{\prime} \mathrm{E}\right), 200 \mathrm{ft}$ (60m) (Ryley, 1913b, p. 472; Khajuria, 1956a, p. 197; Napier, 1985, p. 78). Crump (in Ryley, 1913b) was informed of its abundance on Girnar Mountain $\left(21^{\circ} 30^{\prime} \mathrm{N} 70^{\circ} 33^{\prime} \mathrm{E}\right)$ where it is venerated and provisioned. It also extends in Gujarat into Kachh (= Kutch), some distance from Fort Kanmir (= Kanmer, $23^{\circ} 24^{\prime} \mathrm{N} 70^{\circ} 52^{\prime} \mathrm{E}$ ) (Stoliczka, 1872, p. 220), and occurs at Disa $\left(24^{0} 15^{\prime} \mathrm{N} 72^{\circ} 10^{\prime} \mathrm{E}\right)$ (Nurse, 1900 , p. 337; see also under $S$. e. anchises), Danta $\left(24^{\circ} 11^{\prime} \mathrm{N} 72^{\circ} 46^{\prime} \mathrm{E}\right)$ and Palanpur $\left(24^{\circ} 10^{\prime} \mathrm{N} 72^{\circ} 26^{\prime} \mathrm{E}\right)$ where M. mulatta is again absent (Nurse, 1900; Crump, in Ryley, 1914a, pp. 687-688). In Rajasthan, S. e. achates occurs on Mount Abu (24036'N 72042'E) (McCann, 1933, pp. 619, 623-624; Prakash, 1962 , p. 83; photographs in Hrdy, 1977), at Uria (c. $24^{0} 38^{\prime} \mathrm{N}$ $\left.72^{\circ} 46^{\prime} \mathrm{E}\right)$ (Crump, in Ryley, 1914a, p. 688), and at Jodhpur $\left(26^{\circ} 17^{\prime} \mathrm{N}\right.$ $73^{\circ} 02^{\prime} \mathrm{E}$ ) (photographs in Sommer, 2002). The colour photograph of a troop of $S$. e. achates forming the half title page in Rowe (1996, p. i) was taken at Ranthambhore National Park $\left(26^{0} 03^{\prime} \mathrm{N}\right.$ $\left.76^{0} 30^{\prime} \mathrm{E}\right)$ (N. Rowe, in litt.). The langurs at Jaipur $\left(26^{0} 55^{\prime} \mathrm{N}\right.$ $75^{\circ} 49^{\prime} \mathrm{E}$ ), the nearby Galta Pass (Flower, 1914, p. 66; Wolfe \& Mathur, 1988), Sariska (= Seriska, 27024'N 76024'E) Wildlife Sanctuary (Vogel, 1971), and at Madhav National Park (24050'$25^{\circ} 55^{\prime} \mathrm{N} 77^{0} 15^{\prime}-78^{0} 30^{\prime} \mathrm{E}$ ) (Kankane, 1984) are therefore also probably referable to $S$. e. achates as are probably the desert langurs recorded by Bhargava (1984, p. 43). The population living near Sheo $\left(26^{\circ} 10^{\prime} \mathrm{N} 71^{\circ} 10^{\prime} \mathrm{E}\right)$ in the Barmer District had declined first to two langurs and finally to only one over the ten years to 26 September 1980. A single langur had inhabited the village of Bap $\left(27^{\circ} 20^{\prime} \mathrm{N} 72^{\circ} 20^{\prime} \mathrm{E}\right)$ in the Jodhpur District during the year up to 14 July 1980 . Prakash (1960, p. 40) observed $S$. entellus at Bikaner $\left(28^{\circ} 01^{\prime} \mathrm{N} 73^{\circ} 18^{\prime} \mathrm{E}\right)$.

An "old male...collected by Mr. Crump at Ouda, Balaghat" $\left(21^{\circ} 48^{\prime} \mathrm{N} 80^{\circ} 11^{\prime} \mathrm{E}\right.$, Madhya Pradesh) (Dollman, 1913, p. 439; see 
Wroughton \& Ryley, 1913a, p. 47, but untraced during this study), is long-haired, especially on the shoulder and flank. The chest and limb inner surface hair is long and dense, the rest of the venter sparsely covered with quite short hair (Dollman, 1913, p. 440). In colour it exactly resembles Kathiawar specimens (Dollman, 1913, p. 442). The back is generally "light drab" and "mouse gray" (of Ridgway, 1912), darkening on the rump ("quaker drab" to "benzo brown") to become "drab gray" towards the flank. The tail resembles the rump in colour, gradually paling towards the tip. The venter and long flank hairs are pale creamy white or yellowish. The crown, neck, whiskers and side of the face are pale creamy white; the crown and nape tinged with pale ashy grey which grades posteriorly into the darker colour of the shoulder and back. The arm is "pale greyish liver colour, mixed with white, darkening gradually towards the hands, which are black or very dark brown". The thigh colour is similar but the shank has fairly long white hair which "in some cases" extend to the metatarsal region (Dollman, 1913, p. 440). Balaghat is near the presumed boundary with Semnopithecus entellus entellus but the Singpur $\left(23^{\circ} 13^{\prime} \mathrm{N}\right.$ $\left.81^{\circ} 25^{\prime} \mathrm{E}\right)$ (Hughes, 1884, p. 148) and Kanha National Park $\left(22^{\circ} 17^{\prime} \mathrm{N}\right.$ $80^{\circ} 37^{\prime}$ E) populations (Krishnan, 1972, p. 544, pl. 7; Oates et al., 1994, fig. 3.15) to the north-east are probably referable to $S$. $e$. achates.

Semnopithecus entellus achates apparently skirts $S$. e. anchises via Helwak $\left(17^{0} 22^{\prime} \mathrm{N} 73^{\circ} 44^{\prime} \mathrm{E}\right)$ and Pune $\left(18^{\circ} 32^{\prime} \mathrm{N} 73^{\circ} 52^{\prime} \mathrm{E}\right)$ where it may intergrade with $S$. e. hypoleucos, and via the Sanjay Gandhi National Park $\left(19^{0} 13^{\prime} \mathrm{N} 72^{\circ} 55^{\prime} \mathrm{E}\right)$, Mumbai, Maharashtra (personal observation, 17 March 2002). ZD.1951.610 from Helwak (Wroughton, 1916a, p. 312; Napier, 1985, p. 79), and two Natural History Museum, London specimens (ZD.1837.6.10.2829 , see Napier, 1985 , p. 83) probably collected near Pune, although darker than usual, seem best referred to $S$. e. achates. The possible break in its distribution near Pune perhaps favours separating the northern population subspecifically from the southern one although there is no clear morphological distinction between them. The name Cercopithecus albocinereus Desmarest, 1822 may be a senior synonym of $S$. e. achates or available for the northern population. If distinct, McMaster (1870, pp. 2, 166) believed that "Presbytis Anchises" would include the seemingly paler and longer-haired langurs of the Koodlighee (= Kudligi, $14^{0} 54^{\prime} \mathrm{N} 76^{0} 23^{\prime} \mathrm{E}$ ) Talook. He recommended Goodicottah (= Gudekota, $14^{0} 50^{\prime} \mathrm{N} 76^{0} 38^{\prime} \mathrm{E}$ ), and the rocky ground (c. $14^{0} 50^{\prime} \mathrm{N} 76^{0} 30^{\prime} \mathrm{E}$ ) between Kudligi and Hoorly-Hull (= Huralihalu) as promising sources of specimens. All three localities, however, are south of Vijayanagar $\left(15^{\circ} 19^{\prime} \mathrm{N}\right.$ $\left.76^{0} 28^{\prime} \mathrm{E}\right)$ so their langurs are probably referable to $S$. e. achates. From Vijayanagar this subspecies extends to Nagarhole National Park (c. $\left.12^{\circ} 00^{\prime} \mathrm{N} 76^{\circ} 05^{\prime} \mathrm{E}\right)$ (Ryley, 1913c, p. 494), Dasarladoddi (c. $14^{0} 15^{\prime} \mathrm{N} 78^{\circ} 50^{\prime} \mathrm{E}$, Andhra Pradesh) (where it intergrades with $S$. p. priam), and possibly to Bangalore $\left(12^{0} 58^{\prime} \mathrm{N}\right.$ $77^{0} 30^{\prime} \mathrm{E}$ ), Karnataka (see under $S$. p. priam). The single troop Shortridge (in Ryley, 1913c) saw north of Srimangala $\left(12^{\circ} 011^{\prime} \mathrm{N}\right.$ $75^{\circ} 58^{\prime} \mathrm{E}$ ) had the conspicuous crest of the Nagarhole population.

\section{Pelage colour variation}

The dorsum (including the head) and the entire tail of infant male skull and round skin BNHS.5179, collected (number 717) on 23 February 1912 by G.C. Shortridge at Havasbhavi is pale yellowish-grey, more blackened on the tail. The occiput and shoulders are somewhat paler. It is presumably in transitional coat. Oboussier and Maydell (1960, p. 149) found little individual variation in four specimens from Anshi $\left(14^{0} 59^{\prime} \mathrm{N}\right.$ $74^{\circ} 22^{\prime} \mathrm{E}$ ), Gund and Mandurli (?= Dandeli, $\left.15^{\circ} 15^{\prime} \mathrm{N} 74^{\circ} 37^{\prime} \mathrm{E}\right)$ in North Kanara. The head colour grades into the darker brownish colour of the nape and back. The chest, abdomen and inside of the limbs are reddish-yellow white. The almost black-haired paws, forearm and shank are considerably darker. Six Muki Balaghat (c. $22^{\circ} 00^{\prime} \mathrm{N} 80^{\circ} 30^{\prime} \mathrm{E}$ ) specimens have larger body dimensions but are merely somewhat brighter in colour with a more sharply demarcated paw colour. Subadult male calvarium and round skin BNHS.5140, collected (number 916) on 19 February 1912 by C.A. Crump at Bori $\left(22^{\circ} 27^{\prime} N 7^{\circ} 16^{\prime} \mathrm{E}\right.$, Madhya Pradesh), 1600ft (500m) (Wroughton \& Ryley, 1913a, p. 47) resembles Semnopithecus e. entellus BNHS.5138 from Midnapore, but the pale brown extends, mainly along the midline, almost to the nape. On 6 February 1923, the Faunthorpe-Vernay Expedition collected (number 27) adult male skull and round skin AMNH.54521 at Sanchi (23029'N 77044'E), $1200 \mathrm{ft}(370 \mathrm{~m})$, Bhopal, (Madhya Pradesh). It is a large $S$. e. achates with blackish paws. There is a slim pale brown dorsal band. Langurs at the Sanjay Gandhi National Park have black paws and a pale orange yellow head with moderately black cheeks. The forearm is dark grey, the brachium and shank grey, and the thigh pale orange with grey along the front edge. The dorsum is pale orange, with a grey midline band. The paleyellow-tipped dark grey tail is variously held both in a virtual Sshape and almost straight behind.

The holotype of [Pithecus entellus] elissa is yellowish-white on the venter, tail-tip, whole of the crested head, back of the thigh to the anus, and almost right around the ankle. The rest of the body, including the shoulders, is pale brownish-grey. The limbs are a darker grey than the body. The tail is intermediate between the back and limb colour. The paws are blackish-brown. Paratype, ZD.1914.11.18.15 is more uniformly pale orange brown throughout most of the back. Paratype, ZD.1914.11.18.17 has an extensive incursion of pale greyishyellow from the venter onto the sides of the back. The dorsal colour in juvenile male skull and round skin ZD.1937.5.26.4, collected (number 2560) on 16 February 1913 by G.C. Shortridge at Nagarhole is similar to ZD.1914.11.18.17 but the dorsal midline band is pale orange grey. 
Bengal Langur Semnopithecus (Semnopithecus) entellus entellus (Dufresne, 1797)

\section{Etymology}

At Anchises' funeral games in Virgil's Aeneid, Entellus was an elderly Sicilian hero reproached into boxing Dares when others refrained. Embarrassed at overbalancing as Dares evaded a punch, Entellus retaliated so relentlessly that Aeneas stopped the fight and rewarded him with a bullock. With one blow Entellus sacrificed it to Eryx, his divine trainer, vowing to hang up his boxing-leathers. The scientific name was prompted probably by Entellus' massive frame and the perceived colobine resemblance to old people, reiterated in other names such as anchises, nestor, Presbytis, priam, senex, veter and vetulus. Entellus is a masculine nominative singular proper noun in apposition to the generic name. It is therefore not declined to agree in gender with that of the genus.

\section{Vernacular names \\ Langú (Dalgliesh, 1903).}

\section{Diagnosis}

About average size and weight for Semnopithecus (sensu stricto), S. entellus entellus is a crestless, black-pawed, pale orange subspecies, suffused with greyish-brown on the back, limbs and forward-looped tail. It inhabits southern West Bengal, southern Bihar, southern Chhatisgarh, Jharkhand, northeastern Maharashtra and Orissa in eastern India, with a probably introduced population in western Bangladesh. It intergrades to the west with $S$. e. achates and to the south-west with $S$. e. anchises. It most resembles $S$. e. anchises.

\section{Type specimen}

Rode (1938, p. 208) reported that the "véritable" holotype (not listed by Geoffroy, 1851a, p. 13) of Simia entellus Dufresne, 1797 no longer existed at the Muséum National d'Histoire Naturelle, Paris. Dufresne (1797) did not specify the age or sex of the holotype, but it measured thirty pouces $(810 \mathrm{~mm})$ from the tip of the muzzle to the tail base. The tail slightly exceeded three pieds (c. 980mm). The tail length is long, but not excessive, while the head and body measurement is exceeded only by the $870 \mathrm{~mm}$ claimed by Trouessart (1912, p. 270) for a Kashmir specimen of Semnopithecus entellus. Such dimensions could only be obtained from an adult male but their accuracy is questionable, and both skins may have been stretched during mounting for exhibition. (If the holotype dimensions approximate reality and its pelage colour is faded, the nominotypical subspecies may be wrongly identified.). The "holotype" and "allotype" of Cercopithecus entellus: Desmarest and Virey, 1817 (p. 581), listed by Rode (1938, p. 208, nos. $12 \mathrm{a}$ and $\mathrm{b}$ ), have no status in zoological nomenclature.

\section{Type locality}

Dufresne (1797) merely reported that "L'Entelle habite au Bengale". Although its dull white or dirty straw-colour with whiter tail-tip and black paws (Dufresne, 1797) seem paler than usual for this district, the holotype might have faded through public exhibition. Its type locality is here provisionally restricted to Shibpur, near Kolkata $\left(22^{0} 32^{\prime} \mathrm{N} 88^{\circ} 22^{\prime} \mathrm{E}\right)$, West Bengal, India (see below).

\section{Geographic distribution}

In late January 1842, Blyth (1843a, p. 890; 1843b, p. 171) collected adult male Semnopithecus entellus 27A, and probably juveniles $\mathrm{D}$ and $\mathrm{E}$ of Blyth (1863, p. 11; Anderson, 1881, pp. 35-36, 11a, de) along the banks of a nullah (c. $\left.23^{\circ} 10^{\prime} \mathrm{N} 88^{\circ} 25^{\prime} \mathrm{E}\right)$ a "tide" south of Guptipara $\left(23^{\circ} 13^{\prime} \mathrm{N} 88^{\circ} 25^{\prime} \mathrm{E}\right.$, where Duvaucel shot his altruistic female langur, see under S. e. achates). Similar langur abundance there as the wet season moderated to frequent heavy showers in late July 1842 and the presence of langurs near Kolkata in June made Blyth (1843a, pp. 887-888; 1843b, p. 174) sceptical of seasonal variation in langur distribution. Chandannagar $\left(22^{\circ} 51^{\prime} \mathrm{N} 88^{0} 21^{\prime} \mathrm{E}\right)$, however, the venue for the chiefly late winter visits recorded by Duvaucel (in Cuvier, 1825a) is about midway between Guptipara and Kolkata. Anderson (1879, p. 69, footnote) reported large troops at the Botanical Gardens, (Shibpur, across the river from) Kolkata, only for a few days in spring. Seeking a large series for dissection (about fifty were killed of 108 examined adult female $S$. entellus), Heape (1895, p. 412) was delayed in Kolkata for a month before they arrived "from the jungles on the south bank of the Hugli" in mid January 1891. If langurs were always locally present, Blyth's (1843b, p. 171) 80$\mathrm{km}$ excursion expressly to observe and collect them would seem superfluous. This seasonal variation in distribution may be associated with the Indian langur migration into Bangladesh during October to January to raid winter crops such as pulses, cereals and cotton. Khan $(1984$, p. 35) specified that langurs cross the frontier at about $23^{\circ} 15^{\prime}-45^{\prime} \mathrm{N} 88^{\circ} 45^{\prime} \mathrm{E}$.

Blyth (1847b, p. 732) had not seen Semnopithecus entellus "wild on the eastern side of the river Hoogly, and its absence has often been remarked on the Cossimbazar Island [= Murshidabad District] (formed by the two chief confluents of the Hoogly and the main stream of the Ganges); while it abounds almost everywhere on the western or right bank of the Hoogly and up the Ganges". The Bhagirathi tributary to the west, the Jalangi to the east, and the Ganges to the north, create Kashimbazar or Murshidabad Island. Probably unjustly, T. Hutton (1868, p. 944) doubted Blyth's (1847b) awareness that the name Hugli denotes only the river section below this island. Perhaps misconstruing "the opposite side of the river" as the position of langurs in relation to Blyth's (1843b, p. 174) collecting locality rather than their situation relative to Kolkata, T. Hutton (1868) falsely inferred Blyth's (1843b) langurs were collected at Kishnagur (= Krishnagar, $\left.23^{\circ} 24^{\prime} \mathrm{N} 88^{\circ} 30^{\prime} \mathrm{E}\right)$. Unless alluding to a personal communication, he mistakenly cited Blyth (1843b) for the abundance there of langurs on the left bank of the Jalangi. From the Delhi Gazette of 2 March 1867, T. Hutton (1868, p. 946) reported that the "many thousands" of Krishnagar langurs (five hundred of which had recently been culled) were all descended from a single pair released "many years ago by devotees". The first record of the species in Bangladesh, several groups totalling about 100 individuals discovered by Gittins and Akonda (1982, p. 277) in the villages and fruit gardens around Keshabpur $\left(22^{0} 55^{\prime} \mathrm{N} 89^{\circ} 15^{\prime} \mathrm{E}\right)$ in Jessore District is therefore probably an expansion of this introduced population. 
However, according to Khan (1984, p. 35) knowledgeable informants and old district gazetteers indicate former continuous langur distribution in western Bangladesh from Bogra District $\left(25^{\circ} 30^{\prime} \mathrm{N} 89^{\circ} 30^{\prime} \mathrm{E}\right)$ to the north-eastern boundary of Khulna District $\left(22^{\circ} 45^{\prime} \mathrm{N} 89^{\circ} 30^{\prime} \mathrm{E}\right)$. By about 1970 , this population had declined to six troops of about 90 langurs at the Keshabpur and Manirampur Police Stations in Jessore District, and 3-4 small isolated troops of 75 each near Jhenaidah $\left(23^{\circ} 30^{\prime} \mathrm{N} 89^{\circ} 12^{\prime} \mathrm{E}\right)$ in Jessore District and Jivannagar $\left(23^{\circ} 25^{\prime} \mathrm{N} 88^{\circ} 48^{\prime} \mathrm{E}\right)$ and Meherpur $\left(23^{\circ} 45^{\prime} \mathrm{N} 88^{\circ} 38^{\prime} \mathrm{E}\right)$ in Kushtia District.

J.W. Laidlay obtained an "exceedingly rusty-tinged specimen... in the vicinity of Junghypore" (= Jangipur, $24^{\circ} 28^{\prime} \mathrm{N} 88^{\circ} 04^{\prime} \mathrm{E}$, West Bengal) (Blyth, 1848b, p. 84; not listed in Khajuria, 1956a). Blyth $(1863$, p. 11, 27C) specified that it was an adult female with "lower-parts deeply tinged with rusty-fulvous". It resembled 27B of Blyth (1863, p. 11), Blyth's (1843b, p. 172) darkest Semnopithecus entellus entellus specimen (see under $S$. e. anchises), but was "more brightly coloured on the head, and golden yellow or rusty fulvous on the flanks and under surface, thus approaching S. pileatus" (Anderson, 1881, p. 35, 11c). Khajuria (1956a, p. 198) noted that "the belly is orange" in adult female skin and skull, ZSI.11431 collected on 3 November 1948 by a Z.S.I. Party at Ramkanali (c. $23^{0} 35^{\prime} \mathrm{N} 86^{0} 46^{\prime} \mathrm{E}$ ), $6 \mathrm{~km}$ from Inspection Bungalow, Inanpur, Manbhum District, Bihar (Khajuria, 1956a, p. 197). On his journey from Kolkata to Delhi, Jacquemont (1841, p. 280) saw several troops near Mothoumoni $\left(23^{\circ} 35^{\prime} \mathrm{N} 86^{\circ} 57^{\prime} \mathrm{E}\right)$, obtaining an adult male, but saw no more between there and Bénarès (= Varanasi, $25^{\circ} 20^{\prime} \mathrm{N} 83^{\circ} 00^{\prime} \mathrm{E}$ ) (Geoffroy, 1843b, p. 26). Crump (in Wroughton, 1915b, p. 100), however, reported it protected and plentiful in the small "State" of Chainpur $\left(24^{\circ} 01^{\prime} \mathrm{N} 84^{\circ} 03^{\prime} \mathrm{E}\right)$, but (at Lohra, $300 \mathrm{~m}$, c. $24^{\circ} 30^{\prime} \mathrm{N}$ $85^{\circ} 00^{\prime} \mathrm{E}$ ) secured two of only four langurs he encountered in the Hazaribagh District, Jharkhand. A few strictly protected

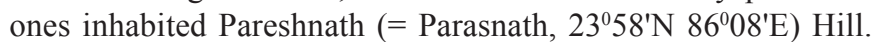
It was widespread, though apparently uncommon in the Santara Range (c. $22^{\circ} 23^{\prime} \mathrm{N} 85^{\circ} 32^{\prime} \mathrm{E}$ ), Singbhum. According to Buchanan (in Jerdon, 1867, p. 4), despite suitable habitat, it was rare in Rajmahal $\left(25^{\circ} 03^{\prime} \mathrm{N} 87^{\circ} 50^{\prime} \mathrm{E}\right)$ (before 1815 , when he returned to Scotland). On 7 September 1847, however, Sherwill (1852, p. $203)$ found it abundant on Maruk hill $\left(25^{\circ} 11^{\prime} \mathrm{N} 86^{\circ} 28^{\prime} \mathrm{E}\right), 1100 \mathrm{ft}$ (350m).

Adult male skull and round skin ZD.1928.3.7.1 collected (number

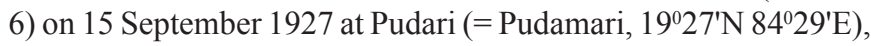
and juvenile female skull and round skin, ZD.1928.3.7.2 collected (number 7) on 25 August 1927 at Ramagiri [Udayagiri] $\left(19^{0} 10^{\prime} \mathrm{N}\right.$ $84^{\circ} 09^{\prime}$ E), both by A.V. Sundaram in the Jeypore Agency, Vizag (= Visakhapatnam) Dist[rict], (Andhra Pradesh) resemble ZD.1915.4.3.4 from Midnapore (see below), but are less grey on the shank. ZD.1928.3.7.2 is orange white, with a pale grey band down the back, and traces of grey on the crown, arm, thigh and tail. The hair is long, silky and crimped. These specimens indicate that those from Cuttack $\left(20^{\circ} 30^{\prime} \mathrm{N} 85^{\circ} 50^{\prime} \mathrm{E}\right)$ (report, in Blyth, 1844b, p. 470; 1847b, p. 732), Goomsoor (= Goomsur,

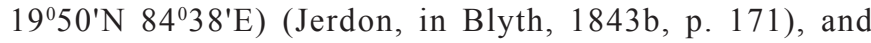
Russelcondah (= Bhanjanagar, 19056'N 84035'E) (McMaster, 1870, p. 2), can be referred to Semnopithecus entellus entellus, which may cross the Ganges into Darbhanga District, Bihar (see under $S$. e. achates). The adult male skull and round skin FMNH.29791 collected (number 56) by K. Roosevelt on 28 December 1925, and adult female skull and round skin FMNH.29792 collected (number 62) the next day by D.S. Ellsworth at Al(1)apalli (?= Arpalli, $\left.19^{\circ} 45^{\prime} \mathrm{N} 79^{\circ} 58^{\prime} \mathrm{E}\right)$, Chanda (= Chandrapur) District, Maharashtra, demonstrate that $S$. e. entellus extends this far west. Both have black paws and forehead. The tail is orange grey. They are otherwise pale orange with pale brown restricted to the lower back and leg, which is darkest at the knee. The forearm is darker.

As far as can be judged from the limited available evidence, the subspecific boundary between Semnopithecus entellus entellus and $S$. e. anchises probably runs between Chandrapur and the Godavari River from just south of Chilka Lake on the Orissa coast to about Akola in Maharashtra. It may coincide with the mode-of-tail-carriage boundary (backward to the south and looped forward to the north) near Arni $\left(20^{\circ} 00^{\prime} \mathrm{N} 78^{\circ} 05^{\prime} \mathrm{E}\right)$, Maharashtra (Roonwal et al., 1984) but evidently runs east of it further to the south-east. The distribution of $S$. e. entellus therefore presumably includes Chhattisgarh and probably runs from Nimar $\left(21^{0} 30^{\prime} \mathrm{N} 76^{0} 20^{\prime} \mathrm{E}\right.$, Madhya Pradesh) to about Visakhapatnam on the Andhra Pradesh coast.

\section{Pelage colour variation}

The paws of juvenile female skull and round skin BNHS.5139 (collector's number 5499) are yellow-streaked black. The limbs, mid section of the tail and mid part of the lower back are pale yellowish-brown. Otherwise it is perhaps artificially more than naturally yellow. Adult male skull and round skin BNHS.5138 (number 5496) is similar, but the black paws are virtually unstreaked with yellow and the tail is pale greyish-yellow brown, except at its root and tip. Adult male skull and round skin BNHS.5137 (number 5508) resembles BNHS.5138 but is brighter yellow. The tail is dark greyish-yellow. An acute-apexed triangle of pale yellowish-brown ceases about half way up the back. Adult male skull and round skin BNHS.5135 (number 5507) resembles BNHS.5137 but the apex of the yellowish-brown lumbar colour reaches the interscapular region. Adult female skull and round skin BNHS.5134 (number 5497) also resembles BNHS.5137 but the knee is orange black. Adult female skull and round skin ZD.1915.4.3.4 (number 5501) is more orange and dorsally less grey than Semnopithecus entellus achates but greyer on the shank. C.A. Crump collected all six specimens from 3 to 12 September 1914 at Midnapore $\left(22^{\circ} 26^{\prime} \mathrm{N} 87^{\circ} 20^{\prime} \mathrm{E}\right)$, $200 \mathrm{ft}$ (60m), [West] Bengal (Wroughton, 1915b, p. 100). Adult male skull and round skin ZD.1915.4.3.3, collected (number 4840) by C.A. Crump on 27 April 1914 at Lohra, (Jharkhand) is less orange and dorsally greyer than ZD.1915.4.3.4. 


\section{Deccan Langur} Semnopithecus (Semnopithecus) entellus anchises Blyth, 1844 Semnopithecus dussumieri: Groves, 2001

\section{Etymology}

Blinded or lamed for bragging of his relationship with the goddess of love Aphrodite, Anchises had to sit out the Trojan War. He was carried from the burning city on the shoulders of their son Aeneas whom he accompanied to Italy. He died at Drepanum in Sicily. Anchises is a masculine nominative singular proper noun in apposition to the generic name. It is therefore not declined to agree in gender with that of the genus.

\section{Vernacular names}

Telugu: Kumdamuchu. Kannada: Karikoti (Wroughton \& Ryley, 1913b, p. 60); Moosya. Dekhani: Langûr (W. Elliot, 1839, p. 95). Marathi: Makur (Sykes, 1831, p. 99; Jerdon, 1867, p. 4); Wanur (W. Elliot, 1839, p. 95; Jerdon, 1867, p. 4).

\section{Diagnosis}

About average size and weight for Semnopithecus (sensu stricto), S. entellus anchises is a crestless, pale-pawed, bright orange subspecies with barely any brown suffusion. It inhabits northern Andhra Pradesh, northeastern Karnataka and eastern Maharashtra in central India. In the east of its range the tail is forward-looped and in the west backward-looped. S. e. anchises intergrades to the south-east with $S$. $p$. priam, to the west with S. e. achates, and to the north-east with $S$. e. entellus, which it most resembles. Napier (1985) followed Pocock (1939) in treating it as a recognizable subspecies intermediate between $S$. p. priam, S. e. entellus and S. e. achates. Groves (2001) considered it a junior synonym of $S$. dussumieri but assigned most of its distribution to $S$. e. entellus.

\section{Taxonomic status}

Semnopithecus entellus anchises Blyth, 1844 was incompletely described because (Sir Walter) Elliot (1803-1887) "to whom the merit is due of first distinguishing these species [S. anchises and $S$. priam], and who is well acquainted with both of them" (Blyth, 1844b, p. 470), failed to fulfil his undertaking to "shortly describe their characters more minutely" (Blyth, 1844b, p. 471). The holotype pelage colour "resembles the darkest" $S$. e. entellus "but has the leg from the knee whitish... the hands mingled white and blackish, and the feet whitish, with dusky black above the base of the toes and on their terminal phalanges; but the coat generally is much longer than in $S$. entellus, the hairs on the sides measuring four [to] six inches [100-150mm] in length, and those...on the toes, and in a less degree those of the fingers, which are very copious, are also remarkably elongated, extending considerably beyond the tips of the toes, which thus present a Spaniel-like appearance" (Blyth, 1844b, p. 470). The hair length indicated to Pocock (1931, p. 53) that "it was killed in mid-winter". Blyth (1863, p. 11 ) listed it as a possible variety of $S$. entellus. An adult female with heavy dental attrition (27B of Blyth, 1863; not listed in Khajuria, 1956a), collected (c. $23^{\circ} 10^{\prime} \mathrm{N} 88^{\circ} 25^{\prime} \mathrm{E}$ ) about $80 \mathrm{~km}$ north of Kolkata (Blyth, 1843a, pp. 887, 890), was the darkest S.e. entellus Blyth (1843b, p. 172) had seen. Its paws are wholly deep black with pale hair intermingled on the foot. The forearm and leg are almost and, in parts, equally as dark as the rump whose colour spreads less deeply through most of the dorsum. Three-quarters of the tail is still darker than the rump, but it pales towards the tip. The venter below the nipples is deeply tinged with a conspicuous orange brown (Blyth, 1843b, p. 173). Anderson $(1881$, p. 35, 11b) described it as "brownish on the middle of the back from the nape to the tail, and dark brown on the outside of the limbs; hands and feet black".

Dollman (1913, p. 443) discounted hair length as especially subject to individual variation and assigned to "Presbytis entellus anchises" specimens from the holotype and paratype localities of Pithecus e. achates, ignoring Samasgi but including Jog, the type locality of $P$. e. iulus Pocock, 1928, and "S.E. Coorg" (presumably Nagarhole), the type locality of [P. e.] elissa Pocock, 1928. At a time when the British Museum had no adult skins unequivocally referable to typical Bengal Semnopithecus e. entellus (Wroughton, 1912a, p. 397), Dollman (1913) diagnosed $S$. anchises as a darker monkey, lacking the silvery sheen so evident on the coat of $S$. e. entellus. The flank and pale crown are more yellowish and the latter more sharply defined from the dark neck and body colour. The back and rump are darker. The limbs, especially the arm, are usually darker. The paws are black or blackish-brown. The venter is usually richer in colour. The tail-tip is more often tufted, generally with a creamy white terminal third.

The British Museum specimen Pocock (1928) nominated as most closely resembling $S[$ emnopithecus] anchises is a pale creamy white adult female (ZD.1914.11.18.13) from Hewra, Nimar (see Napier, 1985, p. 78), noted by Dollman (1913, p. 440) for the long-haired feet which, other than the slightly brown-tinged toes, are drab white. Rather than mid winter it was collected in November-December 1911 (Wroughton, 1912c, p. 844). Pocock (1928, p. 488) inferred that it and two specimens (ZD.1912.2.8.4 and ZD.1912.2.8.6) he considered similar from Lahi (c. $22^{\circ} 27^{\prime} \mathrm{N}$ 77028'E), Seoni Malwa, (Madhya Pradesh) established intergradation between three subspecies, $S$. p. priam, S. e. entellus and $S$. e. achates. Consigning $S$. anchises into limbo, he allowed only that it might be "a variety or sport of either" $S$. e. entellus or his new subspecies $S$. e. achates. Except for shorter pelage, Pocock (1931, p. 53) considered an adult female (ZD.1933.7.29.5) collected in November at Diguvametta $\left(15^{\circ} 23^{\prime} \mathrm{N}\right.$ $\left.78^{0} 50^{\prime} \mathrm{E}\right)$ in the Nallamalai Range, 2000ft (600m, Andhra Pradesh), almost indistinguishable from the Nimar one.

Pale-pawed specimens, however, also occur to the south-west. Infant male skull and round skin BNHS.5716, collected (number 183) on 26 November 1911 by G.C. Shortridge at Devikop is crestless and pale brownish-grey on the arm, foot, tail root and in a band from the nape to the tail, broadening from $70 \mathrm{~mm}$ to $80 \mathrm{~mm}$. The orange black of the cheek extends as a triangle with its apex at the pinna. The paws have some blackish hair. Subadult male skull and round skin BNHS.5180, collected (number 52) on 4 November 1911 by G.C. Shortridge at Alnavar is a Semnopithecus entellus achates, but blackish-brown is virtually restricted to the digits. The forearm is intermediate 
between the anterior and posterior colour on the back. The latter half of the tail is mainly yellow. Paratype ZD.1913.7.5.3 from Alnavar is abnormally orange blond on the anterior part of the back. The hand is blackish-brown, paler on the outside of the wrist than in the three Devikop paratypes. In all four of these paratypes the brownish-black foot is slightly streaked with brownish-grey. Paratype ZD.1913.7.5.4 is abnormally blond on the flank. It and ZD.1914.11.18.5 are ventrally pale orange. In ZD.1913.7.5.3 this is mainly restricted to the mid chest below the nipples. ZD.1914.11.18.4 appears to be a fairly normal S.e. achates.

Two Semnopithecus entellus achates paratypes from Vijayanagar, both resemble dark $S$. e. entellus and both have relatively pale shanks. Both are ventrally more orange than other paratypes and the holotype. In ZD.1914.11.18.8 the shank is greyish-white. In ZD.1914.11.18.9 it is more greyish-yellow. Both have some pale hairs on the hand, especially along the outer edge, with intermingled whitish hair on the proximal phalanx of each finger, except that of the thumb. The blackish colour is pale or absent on the outer side of the back of the hand, whereas in ZD.1915.4.3.4 from Midnapore it is solid at least to the wrist. Neither Vijayanagar paratype has the long spaniel-like hair of ZD.1914.11.18.13, and the foot hair, although longer than the hand hair, is no longer than that of ZD.1915.4.3.4.

Cited by Hill (1939, p. 282) for its unusual colour, male round presumed adult skin BNHS.5149, labelled "Pithecus entellus anchises", was purportedly collected (number 31) on 17 January 1921 by A.P. Kinloch at Seetagundy Estate (c. $\left.10^{0} 35^{\prime} \mathrm{N} 76^{\circ} 45^{\prime} \mathrm{E}\right)$, Kollengode (= Kollangod, Kerala). It seems crestless. It is bright orange, tinged with pale brown on the midline of the back, most of the tail, the outer edge of the knee, and especially on the arm. The fingers are blackish, the rest of the hand blackish-orange. The foot is orange black. Another six specimens in the Bombay Natural History Society collection, labelled as having been collected in September 1931 by C. McCann at Khandala $\left(18^{\circ} 45^{\prime} \mathrm{N} 73^{\circ} 23^{\prime} \mathrm{E}\right), 1600 \mathrm{ft}$ (500m, Maharashtra), closely resemble it.

In March 2002, some specimens in the collection had interchanged labels. For example, a specimen of Semnopithecus pileatus durga was labelled as $S$. p. tenebricus BNHS.5222, and vice versa for BNHS.5219. The Seetagundy label may belong to male round presumed juvenile skin BNHS.5141, labelled "Deesa" (= Disa, $24^{0} 15^{\prime} \mathrm{N} 72^{\circ} 10^{\prime} \mathrm{E}$, Gujarat), but identifiable as $S$. priam priam. Most of the back, arm and tail are pale yellowishbrown. The tail-tip, nape and interscapular region are orange yellow. The leg is similar, with pale brown on the outer edge of the knee. The paws are pale orange yellow, tinged with pale brown on the knuckle. There appears to be a moderately developed crest. A straight swap in labels between these two specimens, however, is improbable because the undated BNHS.5141 has the same collector and collector's number (3171) as FMNH.82810. FMNH.82810 and FMNH.82811 (the latter numbered 3172), both collected on 2 May 1913 by C.A. Crump (Ryley, 1914a, p. 688), establish the Disa population as S. entellus achates. They are brownish-grey, darkest on the central lower back. Most of the shank and venter are pale yellow. The tail is grey, progressively yellowier towards the tip. Its last third is yellow in FMNH.82810, which has yellow sprinkled on its black paws. In FMNH.82811 the hand is brownish-black; the foot yellowish-dark brown. FMNH.82811 is more orange than FMNH.82810 and dorsally paler. Without more reliable contrary evidence, the bright orange population is presumed absent at Seetagundy and the local langur taken to be $S . p$. thersites. Lindsay (1926a, p. 592) recorded no Seetagundy specimen, but determined the holotype of $P$. e. priamellus Pocock, 1928 collected nearby, as $P$. e. anchises. The "Seetagundy" specimen is apparently a mislabelled Khandala specimen. It is unlikely the others have all shed their labels so they seem reliable evidence for a distinctive bright orange population at Khandala. Independent origin of such populations there and in Bengal is conceivable but continuity is indicated by similar specimens from the Chandrapur District, Maharashtra (see under $S$. $e$. entellus), distinguishable only by their black paw colour. The pale paws of south-western specimens justify their subspecific separation from S. e. entellus as S. e. anchises.

\section{Type specimen}

The holotype of S[emnopithecus] anchises Blyth, 1844 was presumably collected during Elliot's employment in the Deccan from 1824 to 1833 (Prinsep, 1885, p. 49), and may well have been the adult male langur weighed and measured by W. Elliot (1839, p. 95). Blyth (1847b, p. 733) specified that Elliot had loaned the skin to the Museum of the Asiatic Society of Bengal but Blyth (1863, p. 11, specimen 27J) recorded its donation in 1847. Anderson (1879, p. 16) reported it absent at the Indian Museum, Kolkata, and regrettably it has evidently not resurfaced (Anderson, 1881; Khajuria, 1956a).

\section{Type locality}

$S[$ emnopithecus $]$ anchises "is the common species of the elevated table-land of the peninsula of India" (Blyth, 1847b, p. 733), and represents $S$. entellus "in the Deccan and along the foot of the western ghauts" (Blyth, 1844b, p. 470). The holotype was probably from W. Elliot's $(1839$, p. 92) mammal catalogue of the "Southern Mahratta Country" in the "part of the high tableland towards the south of the Dekhan". The Krishna and Tungabhadra Rivers bound this "British zillah of Dharwar" to the north and south, the Sahyadri Mountains to the west, and the Nizam's territory (commencing at the Andhra Pradesh border) to the east. Within it, W. Elliot's (1839, p. 94) table records $S$. entellus in the forest on the eastern slopes of the Sahyadris but rare in the red sandstone hills of the east and north-east, and absent from the intervening Mulnad and black plains. As the holotype bears a closer resemblance to langurs from the east rather than from the west of this area, its locality is here provisionally restricted to Raichur $\left(16^{0} 15^{\prime} \mathrm{N} 77^{0} 24^{\prime} \mathrm{E}\right)$, Karnataka.

\section{Geographic distribution}

Other than at Khandala $\left(18^{0} 45^{\prime} \mathrm{N} 73^{\circ} 23^{\prime} \mathrm{E}\right.$, Maharashtra), the distribution of Semnopithecus entellus anchises is inferred from the localities where adjacent subspecies replace or apparently intergrade with it. Judging by the seemingly intermediate 
condition with $S . e$. achates of specimens from Disa $\left(24^{0} 15^{\prime} \mathrm{N}\right.$ $72^{\circ} 10^{\prime} \mathrm{E}$, see above), S. e. anchises may geographically extend to Gujarat. At Sanjay Gandhi National Park $\left(19^{0} 13^{\prime} \mathrm{N} 72^{0} 55^{\prime} \mathrm{E}\right.$, personal observation, 17 March 2002), Pune (18032'N 73052'E) and Helwak $\left(17^{\circ} 22^{\prime} \mathrm{N} 73^{\circ} 44^{\prime} \mathrm{E}\right)$ in Maharashtra, S. e. achates replaces it. It apparently intergrades with $S$. e. achates at Nimar $\left(21^{0} 30^{\prime} \mathrm{N} 76^{\circ} 20^{\prime} \mathrm{E}\right)$ in Madhya Pradesh and at Alnavar $\left(15^{\circ} 26^{\prime} \mathrm{N}\right.$ $\left.74^{\circ} 44^{\prime} \mathrm{E}\right)$, Devikop $\left(15^{\circ} 08^{\prime} \mathrm{N} 74^{0} 56^{\prime} \mathrm{E}\right)$, Vijayanagar ( $\left.15^{\circ} 19^{\prime} \mathrm{N} 76^{\circ} 28^{\prime} \mathrm{E}\right)$ and the restricted type locality, Raichur in Karnataka. Specimens from Seoni Malwa (Madhya Pradesh), however, are less convincingly intermediate and probably referable to $S$. $e$. achates. As far as can be judged from the limited available evidence, the subspecific boundary with $S$. e. entellus probably runs from Nimar to about Visakhapatnam on the Andhra Pradesh coast. This boundary may coincide with the change in mode of tail-carriage near Arni $\left(20^{\circ} 00^{\prime} \mathrm{N} 78^{\circ} 00^{\prime} \mathrm{E}\right)$, Maharashtra, from backward in the south to looped forward in the north (Roonwal et al., 1984) but further south, S. e. anchises apparently displays both modes. $S$. e. anchises is probably the subspecies Nolte (1956, p. 182) saw in small troops near Bhimashankar $\left(19^{\circ} 04^{\prime} \mathrm{N}\right.$ $\left.73^{\circ} 32^{\prime} \mathrm{E}\right)$, and Spillett (1968, p. 8) found common in the Pakhal Wildlife Sanctuary $\left(17^{0} 57^{\prime} \mathrm{N} 79^{\circ} 59^{\prime} \mathrm{E}\right), 850 \mathrm{ft}(260 \mathrm{~m})$. It may intergrade with $S$. p. priam at Diguvametta $\left(15^{0} 23^{\prime} \mathrm{N} 78^{\circ} 50^{\prime} \mathrm{E}\right)$, Andhra Pradesh.

\section{Pelage colour variation}

The Deccan Langur seemed to Jerdon $(1867$, p. 5) to be "decidedly more ashy" with less blackened paws than the Bengal one. BNHS.5170-5175 were all collected at Khandala by C. McCann. With the possible exception of BNHS.5172, they all seem crestless. BNHS.5171-5173 are dated September 1931, and BNHS.5172 and BNHS.5174 have the altitude 1600ft. Skull and round skin BNHS.5171 has deciduous dentition only. Its tail wrapped round the perineum prevents sex determination. It resembles BNHS.5149 (the "Seetagundy" specimen) but with almost no brown on the knee. There is less orange on the back of the hand and its foot is pale orange. The black hairs around the lateral and lower facial margin are sparse. Skull and round skin BNHS.5174 has deciduous dentition only. It is tentatively determined as male from the apparent presence of a penis and seemingly contiguous callosities. It resembles BNHS.5149 but the tail is darker than the arm. The hand is blackish-orange and the foot brownish-orange. The only permanent dentition erupted by skull and round skin BNHS.5175 are the first molars. Its vulva and separated callosities establish it as female. It resembles BNHS.5174 but the hand is orange black. Based on size, BNHS.5170 is an adolescent. Its contiguous callosities and flat nipples diagnose it as male. It resembles BNHS.5171, but the toes are orange black. Based on dental eruption, BNHS.5173 is also an adolescent. Its penis, contiguous callosities and flat nipples establish it as male. It resembles BNHS.5149 but the tail is darker than the knee, the fingers are quite orange, and the foot is tinged with dark grey on the first phalanx. The rest, especially the ends of the toes are pale orange. Based on dental eruption, BNHS.5172 is an older adolescent. Its penis, contiguous callosities, flat nipples, canines and mandibular third premolars establish it as male. It resembles BNHS.5149 but the tail is darker than the knee.

\section{Terai Langur}

Semnopithecus (Semnopithecus) entellus hector (Pocock, 1928)

$S[$ emnopithecus] petrophilus Gray, 1843 (published in synonymy and therefore unavailable)

Presbytis thermophilus Jerdon, 1867 (nomen nudum)

Pithecus entellus schistaceus: Pocock, 1928

Presbytis entellus schistaceous: Roonwal, 1979

\section{Etymology}

The noun phrase petrophilus derives from the Greek noun petra, meaning "rock", and the Greek adjective philos, meaning "loving". It presumably alludes to the perceived habitat preference (Hodgson's manuscript name, in Gray [1843, p. 4]). The noun phrase thermophilus derives from the Greek noun therme, meaning "heat", and the Greek adjective philos. It is presumably a lapsus calami for petrophilus. The eldest son of Priam and Hecuba, Hector was the commander and bravest of the Trojans. For twelve days before being ransomed to Priam, his corpse was dragged by chariot around the tomb of Patroclus, whose death by Hector Achilles avenged. The vagaries of scientific nomenclature have ironically reversed their situation. Hector is a masculine nominative singular proper noun in apposition to the generic name. It is therefore not declined to agree in gender with that of the genus.

\section{Vernacular names}

Pahari: Derdoa (Baptista, in Hinton \& Fry, 1923, p. 404). Hindi: Gooni (Wroughton, 1914, p. 286). Mallaha: Langur (Baptista, in Hinton \& Fry, 1923, p. 404).

\section{Diagnosis}

About average size and weight for Semnopithecus (sensu stricto), S. entellus hector is a crestless, pale-pawed, yellowishwhite to pale orange subspecies, suffused with pale greyishbrown on the back, arm, knee and forward-looped tail. It inhabits southwestern Bhutan, northern India (southern Uttaranchal, northeastern Uttar Pradesh and probably northern West Bengal) and southern Nepal. It intergrades to the north with $S$. e. schistaceus, which it most resembles and to the south probably with $S$. e. achates. Pocock (1939) confused S. e. hector with $S$. e. schistaceus.

\section{Type specimens}

The holotype of S[emnopithecus] petrophilus Gray, 1843 is the specimen figured in Hodgson's drawing (Gray, 1847, p. 1, Presbytes Entellus, item $k$ ). This may be the adult female round skin with skull inside, ZD.1843.1.12.2, collected before 1843 by B.H. Hodgson, designated by Wroughton (1918, p. 559) as paralectotype of S. Schistaceus Hodgson, 1841 and preserved at the Natural History Museum, London (Napier, 1985, p. 81). The holotype of Pithecus entellus hector Pocock, 1928 is an adult male skull and round skin ZD.1914.7.10.10 collected (number 3975) on 21 November 1913. It and four paratypes were collected by C.A. Crump, and are preserved at the Natural History Museum, London. The paratypes are adult male skull and round skin ZD.1914.7.10.12, collected (number 4493) on 21 February 1914; adult male skull ZD.1914.7.10.14 (number 3980); adult female skull and round skin ZD.1914.7.10.11, collected 
(number 4281) on 7 January 1914; and adult female skull and round skin ZD.1914.7.10.13, collected (number 3937) on 6 November 1913 (Wroughton, 1914, p. 286; Pocock, 1928, pp. 482-483; Napier, 1985, pp. 80-81).

\section{Type localities}

The holotype locality of $S[$ emnopithecus] petrophilus is unspecified but it was presumably collected in the Terai south of Kathmandu $\left(27^{\circ} 43^{\prime} \mathrm{N} 85^{\circ} 18^{\prime} \mathrm{E}\right)$, Nepal, where Hodgson was then resident (see under S. e. schistaceus). The holotype of Pithecus entellus hector was collected at Sitabani (c. $29^{\circ} 24^{\prime} \mathrm{N}$ $\left.79^{\circ} 07^{\prime} \mathrm{E}\right), 2000 \mathrm{ft}(600 \mathrm{~m})$. Paratype ZD.1914.7.10.14 was collected at $1100 \mathrm{ft}(350 \mathrm{~m})$, probably at Sitabani; and ZD.1914.7.10.11 at Dela (= Dhela, $\left.29^{\circ} 24^{\prime} \mathrm{N} 79^{\circ} 00^{\prime} \mathrm{E}\right), 1500 \mathrm{ft}(450 \mathrm{~m})$. Both localities are in Ramnagar. Paratype, ZD.1914.7.10.12 was collected at

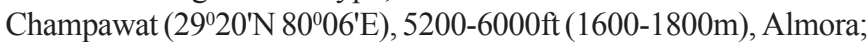
and ZD.1914.7.10.13 at Ratighat $\left(29^{\circ} 30^{\prime} \mathrm{N} 79^{\circ} 29^{\prime} \mathrm{E}\right), 3700 \mathrm{ft}$ $(1100 \mathrm{~m})$, Naini Tal (= Nanital). All four localities are in Kamaon (= Kumaon), Uttaranchal, India (Wroughton, 1914, p. 286; Pocock, 1928, pp. 482-483; Napier, 1985, pp. 80-81).

\section{Geographic distribution}

The minimal geographic distribution of Semnopithecus entellus hector is the Himalayan foothills from the Rajaji National Park (c. $30^{\circ} 10^{\prime} \mathrm{N} 78^{\circ} 00^{\prime} \mathrm{E}$ ), c. $300 \mathrm{~m}$, Uttaranchal, India (Roonwal, 1979b, p. 51, pl. 3; Laws \& Laws, 1984 , fig. 1) to Chatra $\left(26^{0} 51^{\prime} \mathrm{N} 87^{\circ} 10^{\prime} \mathrm{E}\right)$, $500 \mathrm{ft}(150 \mathrm{~m})$ in east Nepal. Its reported occurrence in southwestern Bhutan (Wangchuk et al., 2003) indicates the langurs at about $1600 \mathrm{ft}(500 \mathrm{~m})$ near Punkabari (= Pankhabari, $26^{0} 50^{\prime} \mathrm{N}$ $\left.88^{0} 16^{\prime} \mathrm{E}\right)$ (Jerdon, 1867, p. 6), and the single one Crump's shikari saw in the Terai at Sivok $\left(26^{\circ} 52^{\prime} \mathrm{N} 88^{\circ} 27^{\prime} \mathrm{E}\right)$, West Bengal (Wroughton, 1916b, p. 477) were also S. e. hector. In 1980, Mukherjee et al. (1995, p. 31) observed two troops of 3 and 16 langurs near Coronation Bridge on the Sevoke-Teesta Bazar road but their subspecific identity remains unconfirmed.

In addition to the holotype and paratypes, C.A. Crump collected (number 3848) adult female skull and round skin BNHS.5143 on 10 October 1913 at Takula (c. $\left.29^{\circ} 44^{\prime} \mathrm{N} 79^{\circ} 43^{\prime} \mathrm{E}\right), 5350 \mathrm{ft}(1630 \mathrm{~m})$, Kumaon (Wroughton, 1914, p. 286). N.A. Baptista collected (number 113) adult female skull and round skin ZD.1922.5.16.1 on 15 February 1921 at Hazaria (c. $27^{0} 10^{\prime} \mathrm{N} 85^{\circ} 30^{\prime} \mathrm{E}$ ), Patherghatta, c. $600 \mathrm{ft}(180 \mathrm{~m})$, Nepal (Hinton \& Fry, 1923, p. 404; Pocock, 1928, pp. 477-478; 1939, p. 93; Napier, 1985, p. 81). C.W. Beebe collected (WH 23) adult male round skin AMNH.32653 on 14 May 1910 at Mundali (?= Mandal, $\left.30^{\circ} 27^{\prime} \mathrm{N} 79^{\circ} 17^{\prime} \mathrm{E}\right)$, Garwhal (= Garhwal). S.D. Ripley collected (number 25) adult male skull and round skin USNM.290065 on 20 December 1948 at

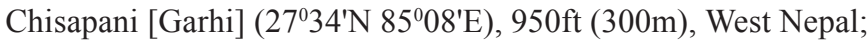
and (number 106) adult male skull and round skin USNM.290066 on 17 February 1949 at Chatra. USNM.290066 may be intermediate with Semnopithecus entellus schistaceus (see below).

Semnopithecus entellus hector has also been collected at Nishangara $\left(28^{0} 15^{\prime} \mathrm{N} 81^{0} 13^{\prime} \mathrm{E}\right), 600 \mathrm{~m}$, Uttar Pradesh, India (see under S. e. schistaceus); and is presumably the subspecies at the nearby Soheli River (= Sarju or Suheli River, c. $28^{\circ} 31^{\prime} \mathrm{N}$ $\left.80^{\circ} 41^{\prime} \mathrm{E}\right)$ (McCann, 1933, p. 624), and of which B.B. Osmaston collected skull ZD.1926.10.8.6 on 20 March 1893 at Bhinga $\left(27^{0} 43^{\prime} \mathrm{N} 81^{0} 56^{\prime} \mathrm{E}\right), 1000 \mathrm{ft}(300 \mathrm{~m})$ (Pocock, 1939, p. 95; Napier, 1985, p. 81). In February with heavy rain and some snowfall, it is seasonally absent from Lohaghat $\left(29^{\circ} 25^{\prime} \mathrm{N} 80^{\circ} 06^{\prime} \mathrm{E}\right), 5600 \mathrm{ft}$ (1700m) (Crump, in Wroughton, 1914, p. 286). Below Beni $\left(28^{\circ} 21^{\prime} \mathrm{N} 82^{\circ} 34^{\prime} \mathrm{E}\right)$, Nepal, on the Kali Gangdaki, just above its confluence with the Trisuli, Byrne (1979, p. 73) observed a "brown variation" of the langur he had seen (p. 70) on the Tula Beri (= Bheri), below Rukumkot $\left(28^{\circ} 37^{\prime} \mathrm{N} 82^{\circ} 37^{\prime} \mathrm{E}\right)$. This indication that $80 \mathrm{~km}$ west of Pokhara $S$. e. hector locally replaces $S$. e. schistaceus is corroborated by Byrne's (1982, p. 115) determination as "Entellus achillis" of the langur on the Nisa Khola, the stream which drains Lake Rara $\left(29^{\circ} 34^{\prime} \mathrm{N} 82^{\circ} 04^{\prime} \mathrm{E}\right)$. From this evidence, only the langurs Chesemore (1970, p. 164) saw in mixed hardwood-pine forests in the valleys north of the Annapurna Massif near Chamchae $\left(28^{\circ} 25^{\prime} \mathrm{N} 84^{\circ} 17^{\prime} \mathrm{E}\right)$ and between Chamay and Thonje $\left(28^{\circ} 31^{\prime} \mathrm{N} 84^{\circ} 22^{\prime} \mathrm{E}\right)$ are probably referable to $S$. e. schistaceus, although others from north of Pokhara between Ulleri and Ghorepani $\left(28^{\circ} 15^{\prime} \mathrm{N} 83^{\circ} 30^{\prime} \mathrm{E}\right)$ may also be of that subspecies or intermediate. The rest from southern Nepal are referable to $S$. e. hector. Their localities are Chandikhola $\left(27^{\circ} 04^{\prime} \mathrm{N} 85^{\circ} 22^{\prime} \mathrm{E}\right)$, the Rapti Valley west of Hetaura $\left(27^{\circ} 26^{\prime} \mathrm{N} 84^{\circ} 59^{\prime} \mathrm{E}\right)$, Russian Camp $\left(27^{\circ} 12^{\prime} \mathrm{N} 85^{\circ} 04^{\prime} \mathrm{E}\right)$, Singaul, Tekan $\left(27^{\circ} 10^{\prime} \mathrm{N} 85^{\circ} 20^{\prime} \mathrm{E}\right)$, USAID Camp $\left(27^{\circ} 12^{\prime} \mathrm{N} 85^{\circ} 13^{\prime} \mathrm{E}\right)$, the Terai zone of far western Nepal at Dhanghari $\left(28^{\circ} 34^{\prime} \mathrm{N} 80^{\circ} 36^{\prime} \mathrm{E}\right)$ and Sukla Phanta $\left(28^{\circ} 50^{\prime} \mathrm{N} 80^{\circ} 11^{\prime} \mathrm{E}\right)$, and the pine-oak forest between Chaur (29017'N 80 $\left.21^{\prime} \mathrm{E}\right)$ and Rupal.

Roonwal (1984, p. 308) described the general colour of Gorakhpur (c. $26^{\circ} 45^{\prime} \mathrm{N} 83^{\circ} 24^{\prime} \mathrm{E}$, Uttar Pradesh, India) examples as "silver grey, with olive brown to rusty patches on the back. The sides and ventral parts dark slaty; the midventral parts sometimes white, contrasting with the slaty sides... Hands and feet gray [sic], not black. Tail grey, long and rope-like, with a white terminal tuft". The black face is less prominently framed by 40 $50 \mathrm{~mm}$ white whiskers and beard than in Semnopithecus entellus schistaceus individuals from Dehra Dun and Mussoorie. The rounded $40-50 \mathrm{~mm}$ wide ischial callosities are deep pink in adult males; similar but less prominent in adult females; and smaller and dirty white in infants and juveniles. In less closely observed but apparently similar Shimla District (Himachal Pradesh) S. e. schistaceus specimens the dark slaty flank is not evident. A possible explanation for the dark flank is that the Gorakhpur population is intermediate between $S$. e. hector and $S$. e. achates. Semnopithecus entellus hector is probably the subspecies Royle (in Ogilby, 1840a, p. 145; 1840b, p. lix) found "common enough in the neighbourhood of Hurdwar [= Hardwar, 29058' N $\left.78^{\circ} 10^{\prime} \mathrm{E}\right]$ in April" and of which Nolte (1956, pp. 181-182) saw a troop near Kansrao $\left(30^{\circ} 05^{\prime} \mathrm{N} 78^{\circ} 08^{\prime} \mathrm{E}\right.$, Uttaranchal); and possibly the one Dodsworth (1914, p. 731) was "surprised to find...romping about on the banks of the the Koshalla [?= Kasauli, 30 $55^{\circ} \mathrm{N} 76^{0} 57^{\prime} \mathrm{E}$, Himachal Pradesh] stream (elevation $2,300 \mathrm{ft}[700 \mathrm{~m}]$ ), which is practically at the base of the Himalayas" and Roonwal (1984, p. 308) briefly sighted between Solan and Kalka (Punjab). The male specimen Wroughton (1914) recorded from Khati $\left(30^{\circ} 07^{\prime} \mathrm{N} 79^{0} 57^{\prime} \mathrm{E}\right)$, Pindar Valley, $7650 \mathrm{ft}(2350 \mathrm{~m})$ is subspecifically indeterminable as its present location is 
unknown. Geographically this subspecies is perhaps best poised for dispersal into Assam but reports of the species there (Walker, 1842, p. 265) and in the Naga Hills, (Nagaland) (Butler, 1875 , p. 332) and more specifically near Bara-Porhar in the Kaziranga Wildlife Sanctuary, Assam (Spillett, 1967, p. 496; Gupta, 1974) are uncorroborated and probable misidentifications of S. pileatus. Lahan and Sonowal (1974, pp. 260,275) recorded only $S$. pileatus in the Baguri II block $\left(26^{0} 35^{\prime} \mathrm{N} 93^{\circ} 16^{\prime} \mathrm{E}\right)$ at Kaziranga. Lluis F. Sanz (pers. comm., 11 March 2002) observed it in the nearby Panbari Forest.

\section{Pelage colour variation}

Wroughton (1916b, p. 477) noted that specimens collected below about $1500 \mathrm{~m}$ (presumably from Kumaon) seem to have a buff tinge to the pure white venter. BNHS.5143 from Takula has pale greyish-yellow feet. The fingers are dark brown sprinkled with yellow hair. The tail, arm, knee area and dorsal trunk are greyish-yellow, most brownish on the rump, arm, knee, distal part of the tail, and especially on the hand. The tail-tip and the rest of the body are yellow. USNM.290065 is pale brownish, including the paws. The fingers, forearm and thigh are browner. The head is whitish-yellow, the venter pale orange. The otherwise similar USNM.290066 is ventrally less orange with blackish-brown digits streaked with yellow, especially on the toes. The forearm but not the thigh is browner than the rest.

The purported locality, "Bhikna Thoree, Chanda Dist., Maharashtra" of adult male skull and round skin FMNH.29793, collected (number 110) by Mrs T. Roosevelt in 1925 is probably an error for Bhikhna Thori $\left(27^{\circ} 21^{\prime} \mathrm{N} 84^{0} 37^{\prime} \mathrm{E}\right)$, Nepal. It is pale yellowish-brown, darker on the shoulder, anterior of the arm and thigh, and slightly darker in the centre of the upper back. The distal part of the paws is missing but is apparently little darker. The head and venter are orange yellow; the nape and tail intermediate with the rest of the dorsal pelage colour.

The Rajaji National Park langurs depicted in the monochrome photograph by Laws and Laws (1984, fig. 1) consistently seem to have a white head and pale shank but the forearm and back colour varies from almost white in one (possibly large juvenile) individual to a fairly uniform darker colour (presumably brown) in another. Some have a relatively pale forearm and an almost white hand. Others have a darker forearm and one such seems to have an almost black hand. Most appear to have a grey hand and a relatively pale back. They are provisionally identified as Semnopithecus entellus hector but may prove to be intermediate with S. e. schistaceus.

\section{Pale-armed Himalayan Langur Semnopithecus (Semnopithecus) entellus schistaceus Hodgson, 1841}

[Semnopithecus] Nipalensis Hodgson, 1841 (published in synonymy and therefore unavailable)

Presbytis lania Elliot, 1909

P [ithecus] entellus achilles Pocock, 1928

Entellus achillis Byrne, 1982

S[emnopithecus] hodie Corbet, 1992 (published in synonymy and therefore unavailable)

\section{Etymology}

The Latin adjective schistaceus, meaning "slaty" (ultimately from the Greek adjective skhistos, meaning "split or laminated"), refers to the dorsal pelage colour. The latinized adjective Nipalensis, meaning "from Nepal", refers to the type locality. The masculine Latin noun lanius means "butcher". D.G. Elliot (1909) presumably intended the Latin adjective laneus, meaning "woollen", describing the pelage texture. Nevertheless, the original spelling should stand. Achilles, son of King Peleus of Phthia, was the protagonist of Homer's Iliad. On being deprived by Agamemnon of his prize the maiden Briseïs, disastrously for the Greeks, he declined to fight until Patroclus' death incited him to revenge. Paris later killed Achilles with a poisoned arrow to the heel, the part held by his mother, the sea-nymph Thetis, as she immersed Achilles in the River Styx for invulnerability. Achilles is a masculine nominative singular proper noun in apposition to the generic name. It is therefore not declined to agree in gender with that of the genus.

\section{Vernacular names}

Himalayan: Dendoa; Hanuman (Siddiqi, 1969, p. 11). Lepcha: Kamba suhú (Jerdon, 1867, p. 6); Sahu kaboo (Crump, in Wroughton, 1916b, p. 477). Bhotia: Kubúp (Jerdon, 1867, p. 6); Piopyaka (Crump, in Wroughton, 1916b, p. 477). Hindi: Langur (Jerdon, 1867, p. 6; Siddiqi, 1969, p. 11).

\section{Diagnosis}

Above average size and weight for Semnopithecus (sensu stricto), S. entellus schistaceus is a crestless, pale-pawed, yellowish-white subspecies, suffused with brown on the back, limbs and forward-looped tail. It inhabits northwestern Bhutan, China (southern Tibet), northern India (Himachal Pradesh, southwestern Jammu \& Kashmir, Sikkim, Uttaranchal), Nepal, probably northern Pakistan and possibly northeastern Afghanistan. It intergrades to the south with $S$. e. hector and to the north with S. e. ajax, which it most resembles. At $26.5 \mathrm{~kg}$, the adult male from Shimla listed by Sugiyama (1976, table 1) is the heaviest recorded langur. Pocock (1939) confused S. e. schistaceus with S. e. hector.

\section{Nomenclature}

Hodgson (1844, p. 285) suspected [Semnopithecus] Schistaceus Hodgson, 1841 "may prove to be two species" and captioned one of his drawings "Lesser Hill Langur, S. petrophilus" (Gray, 1847 , p. 2, item k). Hodgson penned, "Schistaceus \& Petrophilus are both distinct from Entellus" in his copy of Gray $(1847$, p. 1), preserved in the General Library of the Natural 
History Museum, London. Gray (1847, pp. 1-2) recognized three varieties of Nepal langur. The first one, described as "slategrey, head white; fur moderate" from two specimens "of different ages" matches Hodgson's (1841) description of S. entellus schistaceus. It clearly differs from the other two, described as "paler, sides and head white; fur long, rather curling" from an adult specimen "in a bad state", and "nearly white, head rather whiter; fur long and curled" from an "adult and a half-grown specimen", the latter probably skin ZD.1845.1.8.221 in white juvenile pelage. Napier (1985, p. 76) confirmed that Hodgson labelled his two coloured figures of the larger, darker langur as S. schistaceus and his coloured figure of the paler one as "Semnopithecus ? petrophilus, the lesser nipalese langur". Perhaps discouraged by Gray's $(1843 ; 1847 ; 1863)$ refusal to accept it as more than a variety of "Presbytes entellus", Hodgson never published the name. His suspicion that two langur taxa occur in central Nepal was finally vindicated on 18 January 1923 when the holotype of $P[$ ithecus $]$ e. achilles Pocock, 1928 was collected. Pocock (1928) acknowledged its taxonomic divergence from ZD.1922.5.16.1 (from Patherghatta), the sole specimen he conceded to $S$. e. schistaceus. His attempt to identify this binomen was perfunctory. Pocock (1928, p. 479) referred the entire available type series of [S.] Schistaceus to $P$. e. achilles.

The chances that none of Hodgson's four adult type skins at the Natural History Museum, London, pertained to Semnopithecus entellus schistaceus were slim. Pocock (1928) had Gray's (1847) catalogue to guide him and should have detected the distinctly paler paralectotype (Napier, 1985, pp. 76, 81). Instead, although admitting that ZD.1922.5.16.1 confounded Hodgson's (1841) description of S. e. schistaceus as "dark slaty above", Pocock (1928, p. 477) flouted correct taxonomic procedure by determining it alone as $S$. e. schistaceus purely because its "low level" origin accords with his unwarranted abbreviation to "Nepal; the Terai Forest" of the habitat of S. e. schistaceus. In taxon identification a description overrides a purported type locality when they conflict. Of the two subspecies represented by the type series, only the darker one can be described as dorsally "dark slaty". Thomas (1918) had already settled the issue by designating a legitimate syntype as the lectotype. The lectotype skin has faded severely through gallery exposure but displacement of its dorsal hair to reveal the root colour unequivocally identifies it as of the darker taxon. Pocock's (1928) apparent ignorance of Thomas' (1918) designation of Indian mammal lectotypes is reprehensible but a proper examination of the type series should have independently led him to the correct subspecific determination. His holograph inscription "? petrophilus" in the margin beside the name "Presbytis thermophilus" in the Mammal Section (Natural History Museum, London) copy of Jerdon (1867) demonstrates Pocock knew of Hodgson's manuscript binomen. The appropriate approbation of Hodgson's (1844) contribution would have been to validate $S$. petrophilus as the name for the rediscovered second taxon. Pocock's (1928) approach was neither magnanimous nor correct. He later conceded that the specimens previously discriminated by him as $S$. e. hector were subspecifically inseparable from his concept of $S$. e. schistaceus.
Instead of correcting his earlier misidentification, Pocock (1939, p. 92) compounded it by synonymizing the two names.

Corbet (1992, p. 175) cited " $S$. hodie Hodgson, 1841" as a synonym of Semnopithecus entellus, but Hodgson (1841, p. 1212) instigated no such name. The relevant line reads: "Species new. Schistaceus hodie (Nipalensis of Catalogue)", a formal semi-latinized abbreviation for "New species (Nipalensis of [my manuscript] Catalogue) today [named] Schistaceus".

\section{Type specimens}

Gray (1847, pp. 1-2) listed five syntype skins of [Semnopithecus] Schistaceus Hodgson, 1841, two syntype skulls and two syntype post-crania. Horsfield (1851, p. 6) listed two more syntype skins, one of which, ZD.1879.11.21.593, has joined the others at the Natural History Museum, London (Napier, 1985, p. 82). All were collected by B.H. Hodgson. Others he also collected have apparently been destroyed or remain untraced. Thomas (1918, p. 370) designated as lectotype an adult male round skin ZD.1843.1.12.1 and rostrum and mandibular corpus ZD.1845.10.8.4. Hodgson (1836a, p. 524, part 5, pl. 10) listed his figure of the "Head and members of the Langoor monkey of the central region" but not the other two drawings cited by Gray (1847, p. 2, items $j-k$ ) and Napier (1985, p. 76). At least one syntype had therefore been collected by 1836 but Hodgson (1836b, p. 238) indicated that his catalogue was based on specimens collected between 1823-1829.

The holotype of Presbytis lania Elliot, 1909 is an adult female skull and round skin ZD.1909.7.16.1 collected (no number) on 9 April 1909 by F.M. Bailey and preserved at the Natural History Museum, London (D.G. Elliot, 1909, p. 273; [Millard et al.], 1909, p. 549; Pocock, 1928, p. 480; Napier, 1985, p. 81). The holotype of $P[$ ithecus $]$ entellus achilles Pocock, 1928 is an adult male skull and round skin ZD.1926.12.3.1 collected (number 826) on 18 January 1923 by N.A. Baptista and preserved at the Natural History Museum, London (Fry, 1925, p. 525; Pocock, 1928, p. 479; Napier, 1985 , p. 82). The above type specimens of [S.] Schistaceus are paratypes of $P$. e. achilles (see under "Nomenclature") because Pocock (1928, p. 479) qualified his remark that the holotype is the "only specimen certainly assignable to this race in the British Museum" with the phrase "which is labelled with full particulars". Pocock (1928, p. 480) "provisionally" referred to P. e. achilles "four skins from Sikkim which are a little paler and greyer than skins from Nepal, but like them in the length and texture of the winter coat". These Sikkim specimens are therefore ineligible as paratypes (International Code of Zoological Nomenclature, Article 72.4.1).

\section{Type localities}

Hodgson (1841, p. 1212) described the habitat of [Semnopithecus] Schistaceus as "Tarai forest and lower hills, rarely the Kachâr also" with no precise type locality. Hodgson was then resident at Kathmandu $\left(27^{0} 43^{\prime} \mathrm{N} 85^{\circ} 18^{\prime} \mathrm{E}\right)$, Nepal, so it is reasonable to assume the lectotype was collected in the nearest Kachár (the juxta-Himalayan or Alpine region, see Hodgson, 1832, p. 338), immediately to the north, such as at 
Phulung Ghyang, 11250ft (3430m), Nawakot $\left(27^{0} 55^{\prime} \mathrm{N} 85^{\circ} 10^{\prime} \mathrm{E}\right)$ District, where C.O. Maser collected (number 738) adult male skull and round skin FMNH.104168 on 13 May 1967. A typical $S$. entellus schistaceus, its paws are uniform in colour with the limbs and its extreme tail-tip is pale. The holotype of Presbytis lania was collected at Chumbi [Valley] $\left(27^{\circ} 28^{\prime} \mathrm{N} 88^{\circ} 53^{\prime} \mathrm{E}\right), 10,000 \mathrm{ft}$ (3000m), Tibet (D.G. Elliot, 1909, p. 273; Pocock, 1928, p. 480; Napier, 1985, p. 81). The holotype of $P[$ ithecus $]$ entellus achilles was collected in the Kachár at Satthar Hill, 12,000ft (3700m), Gorkha (= Gurkha, $\left.28^{\circ} 00^{\prime} \mathrm{N} 84^{0} 38^{\prime} \mathrm{E}\right) 2$ west, N.W. of Nepal (Fry, 1925, p. 525; Pocock, 1928, p. 479; Napier, 1985, p. 82).

\section{Geographic distribution}

The geographic distribution of Semnopithecus entellus schistaceus apparently parallels to the north that of $S$. e. hector, but wide uncharted areas separate clusters of confirmed localities. In Nepal, it is known from Lake Rara (Byrne, 1982), Rukumkot (Byrne, 1979), Gurkha (Fry, 1925), Nawakot (FMNH) and Tarke Ghyang (FMNH); and in Tibet (= Xizang, China), from Bo Qu, Chumbi and Jilon ( $\left.28^{\circ} 28^{\prime} \mathrm{N} 85^{\circ} 16^{\prime} \mathrm{E}\right)$ Valleys, Motuo, Yadong Kamaqu (c. $\left.27^{\circ} 29^{\prime} \mathrm{N} 88^{\circ} 54^{\prime} \mathrm{E}\right)$ and Zhangmu $\left(28^{\circ} 02^{\prime} \mathrm{N}\right.$ 85055'E) (D.G. Elliot, 1909; Zhang et al., 1981; Feng et al., 1986). In Sikkim (India), Blanford (1888b, p. 30) reported S. e. schistaceus from 7000 to $12,000 \mathrm{ft}(2100-3700 \mathrm{~m})$. In field notes recording that adult male FMNH.35444 led a large troop on almost vertical terrain at Lingtam $\left(27^{\circ} 13^{\prime} \mathrm{N} 88^{\circ} 44^{\prime} \mathrm{E}\right)$, H. Stevens doubted it descends below $6000 \mathrm{ft}(1800 \mathrm{~m})$. Crump (in Wroughton, 1916b, p. 477) reported it apparently absent below Chuntang $\left(27^{0} 37^{\prime} \mathrm{N} 88^{0} 38^{\prime} \mathrm{E}, 1600 \mathrm{~m}\right)$ but fairly plentiful (although restricted to heavy forest) in the Lachen Valley $\left(27^{\circ} 44^{\prime} \mathrm{N} 88^{\circ} 33^{\prime} \mathrm{E}\right)$ from about 5000 to $10,000 \mathrm{ft}(1500-3000 \mathrm{~m})$. A few were observed at Sedonchen $\left(27^{\circ} 15^{\prime} \mathrm{N} 88^{\circ} 46^{\prime} \mathrm{E}, 2100 \mathrm{~m}\right)$. Wangchuk et al. (2003) recorded it in northwestern Bhutan. The following discussion indicates S. e. schistaceus also extends through Uttaranchal, Himachal Pradesh, Jammu and Kashmir, and is probably the subspecies in Pakistan and possibly northeastern Afghanistan.

Oboussier and Maydell (1960, p. 142) noted sexual dichromatism absent in three specimens from the village of Molta, 3000m, in the Tons Valley $\left(30^{0} 30^{\prime} \mathrm{N} 79^{0} 39^{\prime} \mathrm{E}\right)$ about $6 \mathrm{~km}$ from the confluence of the Harki Doon (= Har-ki-Dun, Uttaranchal), and in five from Nishangara $\left(28^{\circ} 15^{\prime} \mathrm{N} 81^{\circ} 13^{\prime} \mathrm{E}\right), 600 \mathrm{~m}$, in the Terai, Bahraich District, Uttar Pradesh (Kurup, 1965, pp. 186, 193). They reported little individual variation in pelage colour but distinct colour differences between the series. The Molta langurs are pale slate grey with an almost white head. The chest, belly, tail-tip and inside of the extremities are similarly pale, almost white. Only the longer hairs around the facial margin are black. The Nishangara langurs are brownish-grey, rather than slate grey, with the virtually white colour of the Molta langurs replaced by a yellowish-white tint "clearly transitional into the reddish-yellow white" (Oboussier \& Maydell, 1960, pp. 143, 149) of Semnopithecus entellus achates. The tail-tip is indistinctly paler. Kurup (1965, p. 194) described the head and nape of one Nishangara specimen as white tinged with buff, and the belly and throat rufous buff. The head, nape, throat and whiskers of another are uniformly whitish, the belly being pale buff. In both, the distal half of the leg is externally paler than the arm. Oboussier and Maydell (1960, p. 143) followed Pocock (1928) in identifying the Molta series as $S$. $e$. hector and the Nishangara series as $S$. e. schistaceus. The Nishangara langurs now can be confidently reassigned to $S$. $e$. hector (see under "Nomenclature"). Oboussier and Maydell (1960, p. 142) adopted Hodgson's (1841) unfortunate term "slate grey". This is inapplicable to $S$. e. hector but, at a pinch, can be applied to S. e. schistaceus or S. e. ajax. The Molta langurs therefore can be discounted as $S$. e. hector. They may be $S$. e. ajax but, of the two subspecies, it is $S$. e. schistaceus whose ventral and head colour is closest to white. The Nishangara specimens have coarser hair than the soft, dense fur of the Molta langurs. That Oboussier and Maydell (1960, p. 143) did not specify it as shorter, nor that the series differ in paw (or forearm) colour, tends to confirm that the Molta langurs are $S$. e. schistaceus, rather than S. e. ajax. Individual variation precludes much taxonomic significance being attached to the distinctness of the tail-tip colour. If the Molta langurs are $S . e$. schistaceus, it is unlikely that $S$. e. ajax occurs south of Molta. Anderson (1881, p. 37, 11aa) described the "head, neck, chest, inside of limbs, and under parts" of a skin (evidently ZSI.12232, now represented by a calvarium only, see Khajuria, 1956a, p. 197 ) donated by T. Hutton in 1848, purportedly from Mussoorie $\left(30^{\circ} 27^{\prime} \mathrm{N} 78^{\circ} 05^{\prime} \mathrm{E}\right.$, Uttaranchal), as "yellow; general colour of the trunk brownish or fuliginous [= sooty or dusky] yellow, and darkest on the shoulders, outside of fore limbs, and thighs; hands nearly black; feet dusky; hair long and profuse on the body, and on the feet; tail concolorous with the body, paling towards the tip". The yellow colour may be an artefact of preservation, but it and the dark paw colour indicate the skin is Semnopithecus entellus ajax. Hutton's description (in Blyth, 1844 b, p. 471) of the Mussoorie langur, however, fits $S$. e. schistaceus. He described it as "dark greyish, with pale hands and feet, white head, dark face, white throat and breast, and white tip to the tail. This is I think the Nepal and Simla species". Unless (improbably) this description is inaccurate, either both subspecies occur at Mussoorie, or ZSI.12232 originated from elsewhere.

Having first identified the Mussoorie and Shimla $\left(31^{\circ} 06^{\prime} \mathrm{N}\right.$ $77^{0} 10^{\prime} \mathrm{E}$, Himachal Pradesh) langur as Semnopithecus entellus hector (Pocock, 1928, p. 483), Pocock (1939, p. 98) re-identified it as S. e. ajax. Sugiyama (1976) tentatively identified the Shimla langur as $P[$ resbytis $]$ e. ajax but Vogel (in Sugiyama, 1976, p. 250 , footnote) suggested it was of "the subspecies schistaceus, referring to Pocock (1939)", i.e. S. e. hector. The white head colour of the Shimla langurs photographed by Sugiyama (1976, pls. 1, 4-7) sharply contrasts with the dark body pelage. If darker brachial hairs are present at all, they seem restricted to the hand. Roonwal (1984, p. 308) confirmed that black is absent from the hand and forearm. It is inferred that the Mussoorie and Shimla subspecies is S. e. schistaceus and that ZSI.12232 came not from there but probably from north of Shimla. The contrast in pelage tone between the Mussoorie and the paler (S. e. hector) Bhimtal langurs in monochrome photographs published by Roonwal (1979b, p. 47, pl. 1) reinforces this conclusion. S. e. schistaceus is therefore probably the 
subspecies Royle (in Ogilby, 1840a, p. 145; 1840b, p. lix) found "from 9000 to $11,000 \mathrm{ft}$ [2700-3300m] ... among the Pine forests in the neighbourhood of Choor [ $=$ Chaur, $\left.30^{\circ} 53^{\prime} \mathrm{N} 77^{\circ} 29^{\prime} \mathrm{E}\right]$, and sometimes even at the verge of the snow-line", and of which Nolte $\left(1956\right.$, p. 181) saw a troop of 50 near Chakrata $\left(30^{\circ} 42^{\prime} \mathrm{N}\right.$ $77^{0} 51$ 'E, Uttaranchal). S. e. hector is evidently absent at Mussoorie, and at the more northerly Shimla, but the distributions of all three subspecies may locally run in parallel, with $S$. e. hector extending along the Uttaranchal-Uttar Pradesh boundary, south of the others. The Kumaon langurs Jerdon $(1867$, p. 6) saw in summer at almost $12,000 \mathrm{ft}(3700 \mathrm{~m})$ may have been $S$. e. schistaceus.

T. Hutton (1837, p. 934) rejected Royle's (1833, p. 19) claim that Semnopithecus entellus ascends to $9000 \mathrm{ft}(2750 \mathrm{~m})$ only in summer, having seen it in winter on Háttú mountain (= Hatto Peak, $\left.31^{\circ} 14^{\prime} \mathrm{N} 77^{0} 30^{\prime} \mathrm{E}\right)$, elevation $10,655 \mathrm{ft}(3250 \mathrm{~m})$, and as high as $8000 \mathrm{ft}(2400 \mathrm{~m})$ at Shimla with hard frosts at night and 100 $130 \mathrm{~mm}$ of snow, and in August at $9000 \mathrm{ft}$ at Nágkunda (= Narkanda, $31^{\circ} 16^{\prime} \mathrm{N} 77^{\circ} 27^{\prime} \mathrm{E}$ ). It perennially occurs at Shimla, but seeks a warmer climate in the deep glens or khads during the winter snow, returning to the heights with the thaw. On a fine, sunny day, however, with snow on the ground, he had seen langurs leaping from tree to tree up and down Jakú Hill $\left(31^{\circ} 06\right.$ 'N $\left.77^{0} 11^{\prime} \mathrm{E}\right), 8115 \mathrm{ft}(2470 \mathrm{~m})$. Hutton (in Blyth, 1844b, p. 472) believed them more abundant in cold than in hot weather. After a snowfall, they crowded into a valley on his Mussoorie estate that opened to the north west. Dodsworth (1914, p. 731) confirmed that large troops "of both sexes and of all ages" occupy the Shimla forests throughout the year. In the Shimla Region at 1800-2200m, and in the Hatto Region at 2700-3200m, Sugiyama (1976, p. 257) found troops often foraged on the colder northern side of a hill. Not even cold heavy winter snow drove them to lower levels. Neither was such migration detected at Junbesi or Melemchi (Bishop, 1979, p. 269; but see under S. e. ajax).

Pocock (1928, p. 480) anticipated incredulity at the apparent identity with Semnopithecus entellus schistaceus of two British Museum Kashmir skins, geographically separated from their type locality, Nepal, by the intervening S. e. ajax. The one remaining of these skins (if more than the skull of the second specimen was ever preserved) is a presumed adult male purportedly shot by Captain Deane on 25 May 1906 from a troop of about twenty at Gugai Nala (c. $\left.34^{0} 38^{\prime} \mathrm{N} 74^{0} 50^{\prime} \mathrm{E}\right), 10,000 \mathrm{ft}$ (3000m), Kishengara R[iver], Gurais, Kashmir, and preserved as a round skin ZD.1907.2.15.1. It has a pale greyish-brown forearm. Most of the hand is missing but appears more yellowish, with indications that the thumb, at any rate, has some blackish-brown hairs. The toes are missing but the rest of the foot is greyish-white. The adult male skull ZD.1910.1.18.65 from "Gugga Nullah, 8-12,000ft [2400-3700m], Kashmere" in May 1909 was presumably obtained nearby. Three USNM Kashmir specimens are also more referable to $S$. e. schistaceus. W.L. Abbott collected (numbers 37-38) both juvenile male skull and round skin USNM.21842; and adult female skull and round skin USNM.21843 on 16 April 1892 at Kaj Nag [Mountains] (c. $34^{\circ} 05^{\prime} \mathrm{N}$ $\left.74^{\circ} 49^{\prime} \mathrm{E}\right), 8000 \mathrm{ft}(2400 \mathrm{~m})$ (True, 1894, pp. 1-2, 11). He collected (number 64) adult female skull and round skin USNM.63470 on 3 October 1895 at Lolab (c. $34^{0} 30^{\prime} \mathrm{N} 74^{0} 35^{\prime} \mathrm{E}$ ) (see True, 1894, p. 4). USNM.21842 is dorsally pale whitish-brown, darkest on the forearm, metacarpals, anterior edge of the thigh (which has a mauve tinge) and distal half of the tail. The rest of the body is yellowish-white, including the tail-tip, head, digits and outer edge of the paws. The index finger is blackish. USNM.21843 is similar but the centre of the rump is more noticeably paler than the upper back. The hands are more yellowish. In both specimens, "the face, ears, palms, and soles were black, and the callosities dusky. The iris is clear brown" (True, 1894, p. 1). USNM.63470 resembles USNM.21843 but its central venter is quite orange-tinged. The holotype of $P[$ ithecus $] e$. achilles (from Gurkha, Nepal) has a pale greyish-brown forearm, more yellow on the hand, and dark brown across the second phalanx of the fingers. The foot is pale greyish-yellow streaked with dark grey. The holotype of Presbytis lania (from Chumbi, Tibet) has a pale greyish-brown forearm and hand, slightly more orange-tinged on the hand. The hair on the second phalanx is brownish-black. The foot is pale greyish-yellow.

Given the greyish-tinged forearm of some Semnopithecus entellus ajax paratypes, Pocock (1928, p. 481) misleadingly described the arms of adults (collected in February to April) from Kangra Valley (c. $32^{\circ} 05^{\prime} \mathrm{N} 76^{\circ} 15^{\prime} \mathrm{E}$ ) as browner than those of adults (collected in December to January) from Chamba Valley (c. $32^{0} 50^{\prime} \mathrm{N} 76^{0} 10^{\prime} \mathrm{E}$ ). His apparent intent was to describe their arms as less blackish. The hand and forearm of the holotype from Deolah (Chamba) are blackish-brown. The metatarsus is blackish-grey, intermingled with yellowish-white hair. The toes are predominantly yellowish-white. ZD.1923.9.1.1 from Chatri (Chamba) has a dark brown hand and forearm. The metatarsus is blackish-grey brown, intermingled with yellowish-white hair. The toes are mainly yellowish-white. ZD.1923.9.1.2 from Baira (Chamba) has a dark brown forearm and most of the hand, with blackish-brown hair between the first and second phalanges. The foot is fairly uniform brownish-grey. The toes are pale greyish-yellow. BNHS.5167 from Chalan (Chamba) has the hand and forearm blackish-brown with some orange hair. The brachium, head, flank, venter, last $150 \mathrm{~mm}$ of the tail and lateral edge of the foot are orange yellow. The shoulder, thigh and midline band of the back are yellowish-brown. The shank, rest of the foot and tail are pale greyish-brown, intermingled with yellow hair towards the tail root. Whereas ZD.1923.9.1.119 from Kangra has a pale greyish-brown forearm and most of the hand, with blackish-brown hair across the knuckles and between the first and second phalanges. ZD.1928.7.11.1 from Kangra Fort has a brown forearm and most of the hand, with dark brown hair across the knuckles and between the first and second phalanges. Both specimens have a fairly uniform pale greyishyellow foot. ZD.1933.12.1.1 from Chichian (Kangra) has a greyish-brown forearm and hand, dark brown across the knuckles. The foot is pale brownish-yellow. BNHS.5166 from Samayala (Kangra) resembles BNHS.5167 but is generally paler. The two examined Kullu Valley paratypes support Pocock's (1928) implication that the paler arms of three Kullu females (collected in June) resemble those of the Kangra paratypes. ZD.1928.7.11.3 from Rahla has a mainly pale orange brown 
forearm and hand, with blackish-brown across the knuckles. The foot is pale brownish-yellow. BNHS.5168 from Jagatsukh is shaggy-haired. The head, venter and last $140 \mathrm{~mm}$ of the tail are orange white. In this order, the pale brown thigh, tail, rump and interscapular region are increasingly yellowish, with brownish-yellow hair on the rest of the back. The arm grades from pale brown at the shoulder to dark brown on the forearm and hand, sprinkled with some yellowish hair on the hand. The fingers are mainly blackish. The shank is pale brownish-yellow. The foot is orange yellow, more greyish towards the toes.

Pocock's (1928, p. 481) correlation of the month of collection to the arm colour, and his remark that in June, Kullu paratypes "still carry the winter coat but it is very shaggy and wavy", intimate a deduction that the pale arm colour assumed in February darkens in July. The only USNM specimen unequivocally referable to Semnopithecus entellus ajax is adult male skull, skeleton and round skin USNM.174083 collected (number 7636) by W.L. Abbott at Nath Nye, Dachin (Nullah), Khistwar (= Kishtwar, $\left.33^{\circ} 19^{\prime} \mathrm{N} 75^{\circ} 46^{\prime} \mathrm{E}\right)$ on 20 April 1911, when Pocock (1928) would most confidently have expected a pale arm. The forearm, hand, hallux and next toe, however, are blackish-brown, almost black along the anterior edge of the hand. The anterior edge of the knee is dark brown; the thigh and interscapular region brown. The superciliary and facial hair are blackish. The tail-tip, head and venter are whitishyellow, slightly brownish on the nape and most orange on the lower chest. The rest of the dorsum is pale brown, almost white on the rump and tail root. Instead of seasonal pelage colour variation, this suggests intergradation with $S$. e. schistaceus in the Kangra and Kullu Valleys, and true $S$. e. ajax only in the Chamba Valley (Himachal Pradesh) and at Kishtwar (Jammu and Kashmir), India. The langurs recorded by Gaston et al.

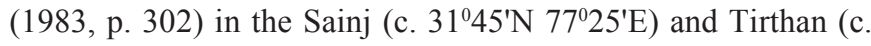
$31^{\circ} 40^{\prime} \mathrm{N} 77^{\circ} 30^{\prime} \mathrm{E}$ ) valleys, and near Kasol (c. $32^{\circ} 00^{\prime} \mathrm{N} 77^{\circ} 20^{\prime} \mathrm{E}$ ) in the Parbati Valley, Himachal Pradesh, and the single troop of 33 individuals sighted by Malhotra and Sahi (1982) in subtropical pine forest at Katra $\left(32^{\circ} 59^{\prime} \mathrm{N} 74^{0} 57^{\prime} \mathrm{E}\right)$ in Jammu province, Jammu and Kashmir, are therefore here referred to $S$. e. schistaceus.

Pocock's (1928) assertion that in young Semnopithecus entellus ajax the back and arm pelage colour is much paler; the long dense coat woollier; and the coarser glistening hair of the adult coat virtually absent, rests on a maximum of four, perhaps on only two juvenile paratypes. Lindsay (1926b, p. 599) listed only three juveniles, one of which was said to be a male from Gopalpur (c. 32006'N 76016'E), 9000ft (2750m), Kangra Valley. This is probably skull and round skin, ZSI.12136 of unspecified age and sex, listed by Khajuria (1956a, p. 196) as collected at Chatri on 1 December 1922. The date favours Chatri as the correct locality. The lack of cited measurements corroborates it as a juvenile. Like FMNH.82813, its paratype status is equivocal because it is unclear whether Pocock (1928) examined it. The forearm of juvenile ZD.1928.7.11.2 from Kangra is darker than the brachium but resembles the pale grey dorsal band, except that it is tinged with pale orange, especially on the lateral edge of the hand. The foot is yellowish-grey; the toes whitish-orange. The hand and forearm of juvenile ZD.1928.7.11.4 from Chatri are pale orange brown, darker than the dorsum which is pale greyish-orange, medially streaked with brown. The thumb is pale orange; the foot similar, tinged with pale brown on the knuckles. Juvenile FMNH.82813 from Chalan resembles $S$. e. hector, but has a dark hand and forearm, and the tail-tip and periphery of the paws are yellowish. ZD.1928.7.11.2 has its complete deciduous dentition only. ZD.1928.7.11.4 has its deciduous dentition plus the first permanent molars. FMNH.82813 shows the same condition as in ZD.1928.7.11.4, but with the first permanent incisors erupted, and second incisors and second molars erupting. These three specimens are therefore compatible with the inference that arm colour darkens with age, but the above evidence favours a geographic interpretation.

While with a field party of the Zoological Survey of India in June 1955, Khajuria (1956b, p. 464) encountered a troop of about fifty langurs (probably including a number of family parties) preoccupied in eating wild fruit at $8000 \mathrm{ft}(2400 \mathrm{~m})$ on the hills just behind Nishat Garden (c. $34^{0} 13^{\prime} \mathrm{N} 74^{0} 55^{\prime} \mathrm{E}$ ) about $13 \mathrm{~km}$ northeast of Srinagar, Kashmir Valley. Some individuals observed at close range were identified as Semnopithecus entellus ajax. Khajuria (1956b) had for comparison only two specimens, one a definite (adult female) paratype ZSI.12135 from Rahla (Kullu), and the other ZSI.12136 (see above), so his identification at best allows that the population near the Nishat Garden may be intermediate between $S$. e. schistaceus and $S$. e. ajax. More recent evidence suggests it is probably $S$. e. schistaceus. During April to May 1981, Tak and Kumar (1984, p. 204) noted a virtual absence of black in the paws of the langurs in a single troop of about 60 at Zahil Nallah (c. $34^{\circ} 12^{\prime} \mathrm{N} 75^{\circ} 00^{\prime} \mathrm{E}$ ), $2285 \mathrm{~m}$, in the Dachigam National Park about 20km north-east of Srinagar; and in a troop of 20 at Gomeri Nallah (c. $\left.34^{0} 09^{\prime} \mathrm{N} 74^{0} 55^{\prime} \mathrm{E}\right), 3000 \mathrm{~m}$, in the proposed Ovra Sanctuary about $28 \mathrm{~km}$ south-east of Srinagar. If $S$. e. ajax occurs near Nishat Garden then these troops to the east should more closely rather than less closely conform with it. Tak and Kumar (1984, pp. 202, 204) identified them as "Presbytis entellus ?schistaceous" $(=S$. e. hector) but tellingly added that " $P$. e. achilles... is very similar to schistaceous [sic] and may be its synonym".

No reported study skins exist for langurs west of Lolab (Jammu and Kashmir). The above evidence indicates the principal Pakistan subspecies is Semnopithecus entellus schistaceus, but whether $S$. e. ajax also occurs there remains to be seen. Roberts (1997, p. 128) determined the Pakistan subspecies as $S$. e. ajax but his implication that "silvery-black hairs" are equally widespread on "both fore and hind limbs" favours $S$. e. schistaceus. Implicitly accepting Roberts' (1977) identification, Roonwal's (1979a, p. 245; 1979b, p. 54) only evidence that the tail-tip in standing or walking $S$. e. ajax touches the back or trails down the flank, was Roberts' (1977, p. 88; 1997, p. 128) figure, purportedly based on photographs of an adult female from Shogran $\left(34^{0} 37^{\prime} \mathrm{N} \mathrm{73}{ }^{\circ} 28^{\prime} \mathrm{E}\right)$, Hazara District. This anomalous implication that the Pakistan population resembles the Northern Plains Langur rather than the Himalayan Langur in tail carriage indicates either confusion over the origin of the photographs or undue licence in the execution of the resulting figure. 
Although both local populations are possibly intermediate with S. e. schistaceus, records from Melemchi, Nepal (Bishop, cited by Roonwal, 1979a, p. 247; 1979b, p. 54, fig. 5) and from Rolla Bhandar (c. $\left.31^{\circ} 50^{\prime} \mathrm{N} 77^{\circ} 40^{\prime} \mathrm{E}\right), 2100 \mathrm{~m}$, in the Kullu District, Himachal Pradesh, India (Tak, in Roonwal, 1981b, p. 27), indicate that as in S. e. schistaceus and S. e. hector (see Appendix) the tail-tip in $S$. e. ajax is suspended above the back. Until proven otherwise, it is safer to assume the same of the Pakistan population.

Siddiqi (1969, p. 11) recorded Semnopithecus entellus in Hazara District at Kaghan (= Kagan, 34047'N 73032'E), Kalam (35032'N $72^{\circ} 35^{\prime} \mathrm{E}$ ) and Siran [River] (c. Baffa, $\left.34^{\circ} 26^{\prime} \mathrm{N} 73^{\circ} 13^{\prime} \mathrm{E}\right)$. Roberts (1997, p. 129) encountered it in late May at $3300 \mathrm{~m}$ feeding in sub-alpine scrub in the Kaghan Valley. He also recorded it in Hazara District on the southeastern face of the Kunhar Valley around Shogran, in Dhanial forests $\left(34^{\circ} 36^{\prime} \mathrm{N} 73^{\circ} 38^{\prime} \mathrm{E}\right)$, and around Shahran (= Sharan Forest Rest House, $\left.34^{\circ} 43^{\prime} \mathrm{N} 73^{\circ} 59^{\prime} \mathrm{E}\right)$, west of the Kunhar River, extending up to Khadir Gali (= Kadir Gali, $34^{\circ} 41^{\prime} \mathrm{N} 73^{\circ} 42^{\prime} \mathrm{E}$ ), above Mahandri. In Azad Kashmir it occurs in the Jhelum Valley (c. $32^{\circ} 57^{\prime} \mathrm{N} 73^{\circ} 44^{\prime} \mathrm{E}$ ) at Mundkro Forest and at Kazinag, Machayara and Phala/Kutbor (c. $34^{\circ} 00^{\prime} \mathrm{N} 73^{\circ} 35^{\prime} \mathrm{E}$ ) (Nawaz, 1983). Surveys in 1994 reported sightings at 3200m near Mukchaki Village in the remote and secluded Palas Valley $\left(35^{\circ} 08^{\prime} \mathrm{N} 73^{\circ} 03^{\prime} \mathrm{E}\right)$ in Indus Kohistan. Reports of its existence on the higher mountain slopes in the north of Amb State (c. $34^{\circ} 18^{\prime} \mathrm{N}$ $72^{0} 51$ 'E) are unconfirmed. Roberts (1997) doubted such southward langur dispersal into the comparatively poorlyforested foothills. He estimated the total Pakistan population at well below 200, but seemed unaware of its presence at Kalam. Evidence of langurs in Afghanistan is slim. Kullman (1965, p. 16), cited by Hassinger (1973, p. 31), tentatively identified as a langur the long-tailed monkey described to him in Mangalpur $\left(34^{\circ} 06^{\prime} \mathrm{N} 69^{\circ} 51^{\prime} \mathrm{E}\right)$. Naumann and Nogge $(1973$, p. 93) similarly speculated on the identity of the black-and-white monkey other than a macaque Naumann was told occasionally entered the Mangalpur vicinity. Raverty $(1859$, p. 332) reported that in "some of the warmer parts of Káfiristán [= Nurestan, c. $35^{\circ} 30^{\prime} \mathrm{N}$ $\left.71^{\circ} 30^{\prime} \mathrm{E}\right]$, in the densely wooded districts, monkeys of the largest size are found, but are not very numerous". Fooden (2000, p. 159) recorded Macaca mulatta from Nurestan. M. mulatta specimens from Pakistan (adult measured specimens from Afghanistan were unavailable) are not especially large (Fooden, 2000, fig. 8). The large Afghanistan monkeys may therefore be langurs.

\section{Pelage colour variation}

Trouessart (1912, p. 270) described a mounted skin, with skull inside, of an adult male langur from Kashmir, acquired from M. Deyrolle in 1885, No. 90a of the Zoology Gallery Catalogue, as generally yellowish-grey, darkening to grey brown in a large triangular nuchal patch, which dwindles and dilutes along the dorsal midline. It ramifies as a $50 \mathrm{~mm}$ wide dark band running down the shoulder and brachium to expand on the forearm and back of the hand where many hairs are black. A large grey brown dorsal thigh patch ceases at the knee. The similarly grey brown foot hairs have whitish tips. The venter and ventral limb surface are a paler grey. The tail resembles the back in colour, darker in the mid region, and ending in a whitish tuft. The head colour grades from yellowish-grey to almost white.

Anderson (1881) described the dorsal pelage colour of an adult male Sikkim skin and another adult Sikkim skin of unspecified sex (the latter specimen, preserved at the Indian Museum, Kolkata is ZSI.12181 of Khajuria, 1956a, p. 197) as "dark slaty, darkest on the outside of the fore limbs, passing almost into blackish on the fingers; dark on the thighs, but paling towards the ankle and passing almost into blackish on the toes. Tail concolorous with the back, becoming darker towards the tip. Head pale yellow, nearly white; chin, throat, chest and under parts, and inside of limbs, yellowish. Fur wavy, profuse, and long" (Anderson, 1881, p. 38). A juvenile (ZSI.12157 of Khajuria, 1956a, p. 197) was more yellow-headed, and its feet paler. L. Mandelli donated all three in November 1875. Mandelli, presumably contemporaneously, also collected ZD.1891.10.7.6 in Sikkim. Its dorsal pelage colour is pale brown, darker in a broad posteriorly bowed crescent spanning from shoulder to shoulder. Pocock (1928, p. 480), claiming Blanford found Mandelli's localities unreliable, conjectured that ZD.1891.10.7.6 came from Nepal rather than from Sikkim. Pocock (1928) perhaps confused Mandelli with Hodgson whose specimens collected after 1843 in Darjeeling and Sikkim are sometimes presumed to have originated from Nepal.

Adult female skull and round skin BNHS.5165, collected (number 6201) on 3 January 1915 by C.A. Crump at Chuntang, 5300ft $(1600 \mathrm{~m})$, is pale yellowish-brown on the upper part of the back, less brown on the arm and especially the hand, brownish-yellow on the lower part of the back, and pale brownish-yellow on the shank. The thigh is separated from the somewhat paler rump by a yellowish dorsal tract across the hip. The tail is intermediate in colour between that of the rump and thigh. The feet are pale yellow with faint blackening on the toes. The fingers are blackish-brown; the eyebrows black. The tail is only slightly paler ventrally than dorsally. The rest of the head and venter are yellowish-white, most yellowish on the head. In comparison to adult female skull and round skin FMNH.35816 (collected, number 933, by V.S. La Personne on 17 June 1931 at Lachung, $27^{\circ} 42^{\prime} \mathrm{N} 88^{\circ} 45^{\prime} \mathrm{E}$ ); adult male skull and mounted skin FMNH.35444; and adult female skull and round skin FMNH.35445 (both collected, numbers 730 and 827, by H. Stevens on 3 and 28 February 1931, respectively, at Lingtam [27 $\left.13^{\prime} \mathrm{N} 88^{\circ} 44^{\prime} \mathrm{E}\right], 6200 \mathrm{ft}$ [1900m]), juvenile female skull and round skin FMNH.35817 (collector's number 934, but otherwise with identical data to FMNH.35816) is relatively pale, with a golden sheen. Juvenile female skull and round skin FMNH.35818, collected (number 922) by V.S. La Personne on 28 May 1931 at Lachen $\left(27^{\circ} 44^{\prime} \mathrm{N} 88^{\circ} 33^{\prime} \mathrm{E}\right)$, 9000ft $(2750 \mathrm{~m})$ is intermediate. There is a small brownish-grey midline patch above the umbilicus in infant male skull and round skin FMNH.35446 (collector's number 829, but otherwise with identical data to FMNH.35445). The dorsum and tail are tinged with blackish-grey. The tail-tip and the rest of the body are white. All three localities are in Sikkim (see Sanborn, 1932, pp. 181-182). Adult male skull and round skin FMNH.105537 and juvenile (doubtful female) skull and round skin FMNH.105538, 
both collected (numbers 5 and 6, respectively) by R.M. Mitchell on 3 and 4 November 1967, respectively, at Tarke Ghyang, 7975ft (2400 m), Helambu Valley (Sindu District), Nepal, are relatively pale for Semnopithecus entellus schistaceus, especially posteriorly. The paw periphery is slightly darker than the limb. The tail-tip is barely paler than the rest of the tail.

\section{Dark-armed Himalayan Langur Semnopithecus (Semnopithecus) entellus ajax (Pocock, 1928)}

\section{Etymology}

Two Greeks named Ajax fought in the Trojan War but as Pocock (1928, p. 480) compared Pithecus entellus ajax with $P$. e. achilles he presumably had in mind the bravest and handsomest of the Greeks after Achilles, Ajax, king of Salamis and son of Telamon. Well-matched with Hector in more than one combat, Ajax ran amok and then killed himself when Achilles' divine armour was posthumously awarded to Odysseus. Ajax is a masculine nominative singular proper noun in apposition to the generic name. It is therefore not declined to agree in gender with that of the genus.

\section{Vernacular names}

Vernacular names employed in the geographic distribution of this subspecies are unrecorded.

\section{Diagnosis}

Above average size and weight for Semnopithecus (sensu stricto), S. entellus ajax is a crestless, yellowish-white subspecies, suffused with brown on the back, limbs and forwardlooped tail, darkest on the hand and forearm. It inhabits northern India (northern Himachal Pradesh, southern Jammu \& Kashmir) and northcentral Nepal. It most resembles, intergrades with and replaces $S$. e. schistaceus to the north, not to the west as Groves (2001) assumed.

\section{Type specimens}

The holotype of Pithecus entellus ajax Pocock, 1928 is an adult male skull and round skin ZD.1928.7.11.5, collected (number 3287) on 7 January 1923. It and eight paratypes are preserved at the Natural History Museum, London. The paratypes are adult male skulls and round skins ZD.1923.9.1.1, collected (number 3092) on 2 December 1922; ZD.1923.9.1.2, collected (number 3131) on 10 December 1922; and ZD.1928.7.11.1, collected (number 2295) on 31 March 1922; juvenile male skull and round skin ZD.1928.7.11.2, collected (number 2300) on 2 April 1922; and adult female skulls and round skins ZD.1923.9.1.119 collected (number 2299) on 1 April 1922; ZD.1928.7.11.3, collected (number 2371) on 4 June 1922; and ZD.1933.12.1.1, collected (number 2128) on 20 February 1922; and juvenile female skull and round skin ZD.1928.7.11.4, collected (number 3091) on 1 December 1922 (Napier, 1985, pp. 79-80). Three paratypes preserved at the Bombay Natural History Society, Mumbai, are adult male skull and round skin BNHS.5167, collected (number 3199) on 21 December 1922; adult female skull and round skin BNHS.5166, collected (number 2231) in March 1922; and adult female round skin BNHS.5168, collected (number 2497) on 30 June 1922. One paratype (presumed adult female) preserved at the Indian Museum, Kolkata, is skull and round skin ZSI.12135, collected (number unpublished) on 4 June 192[2] (Khajuria, 1956a, p. 196). A possible paratype (it is uncertain whether Pocock, 1928, examined it) preserved at the Field Museum of Natural History, Chicago, is juvenile male skull and round skin FMNH.82813, collected (number 3224) on 23 December 1922. H.W. Wells collected the entire series.

Type localities The holotype of Pithecus entellus ajax was collected at Deolah (?= Deosar, $\left.32^{\circ} 18^{\prime} \mathrm{N}_{76} 6^{0} 36^{\prime} \mathrm{E}\right), 6000 \mathrm{ft}(1800 \mathrm{~m})$. Paratype ZD.1923.9.1.2 was collected at Bara (= Baira, 32 ${ }^{\circ} 54^{\prime} \mathrm{N}$ $\left.76^{0} 09^{\prime} \mathrm{E}\right), 7500 \mathrm{ft}(2300 \mathrm{~m})$, Tissa (= Tisa, $\left.32^{\circ} 50^{\prime} \mathrm{N} 76^{\circ} 09^{\prime} \mathrm{E}\right)$; BNHS.5167 and FMNH.82813 at Chalan, 6700ft (2000m), Tissa; ZD.1923.9.1.1 and ZD.1928.7.11.4 at Chatri $\left(?=\right.$ Ghitrari, $32^{\circ} 27^{\prime} \mathrm{N}$ $\left.76^{\circ} 22^{\prime} \mathrm{E}\right), 6000 \mathrm{ft}(1800 \mathrm{~m})$. All four localities are in Chamba (Valley). ZD.1933.12.1.1 was collected at Chichian (c. 32 $\left.06^{\prime} \mathrm{N} 76^{\circ} 16^{\prime} \mathrm{E}\right)$, 9000ft (2750m); ZD.1923.9.1.119 and ZD.1928.7.11.2 at Kangra $\left(32^{\circ} 06^{\prime} \mathrm{N} 76^{\circ} 16^{\prime} \mathrm{E}\right), 2400 \mathrm{ft}(700 \mathrm{~m})$; ZD.1928.7.11.1 at Kangra Fort (c. $\left.32^{\circ} 05^{\prime} \mathrm{N} 76^{\circ} 16^{\prime} \mathrm{E}\right), 2450 \mathrm{ft}(750 \mathrm{~m})$; and BNHS.5166 at Samayala (c. $\left.32^{\circ} 10^{\prime} \mathrm{N} 76^{\circ} 25^{\prime} \mathrm{E}\right), 9500 \mathrm{ft}(2900 \mathrm{~m})$. These four localities are in Kangra Valley. BNHS.5168 was collected at Jagatsukh $\left(32^{\circ} 12^{\prime} \mathrm{N}\right.$ $\left.77^{\circ} 12^{\prime} \mathrm{E}\right), 11,000 \mathrm{ft}(3350 \mathrm{~m})$; ZD.1928.7.11.3 and ZSI.12135 at Rahla $\left(32^{\circ} 21^{\prime} \mathrm{N} 77^{0} 12^{\prime} \mathrm{E}\right), 9800 \mathrm{ft}(3000 \mathrm{~m})$. These two localities are in Kulu (= Kullu) Valley (Lindsay, 1926b, p. 599; Pocock, 1928, p. 481; 1939, pp. 97-98; Khajuria, 1956a, p. 196). The holotype and paratype localities are all in Himachal Pradesh, India.

\section{Geographic distribution}

The specimens described in the Introduction and under Semnopithecus entellus schistaceus confirm S. e. ajax only from the Chamba Valley (c. 32050'N 76 $10^{\prime}$ E) in Himachal Pradesh; from Kishtwar $\left(33^{\circ} 19^{\prime} \mathrm{N} 75^{\circ} 46^{\prime} \mathrm{E}\right)$ in Jammu and Kashmir, India; and apparently from Melemchi $\left(28^{\circ} 03^{\prime} \mathrm{N} 85^{\circ} 33^{\prime} \mathrm{E}\right)$ in Nepal. It intergrades with $S$. e. schistaceus in the Kangra (c. $32^{\circ} 05^{\prime} \mathrm{N}$ $76^{\circ} 15^{\prime} \mathrm{E}$ ) and Kullu (c. $32^{\circ} 17^{\prime} \mathrm{N} 77^{\circ} 12^{\prime} \mathrm{E}$ ) Valleys, Himachal Pradesh; in the Helambu Valley, Nepal; and possibly at Srinagar $\left(34^{0} 05^{\prime} \mathrm{N} 74^{0} 49^{\prime} \mathrm{E}\right)$ in the Kashmir Valley.

Lydekker (1877, p. 284) sighted presumably Semnopithecus entellus ajax "a short distance above Kishtwar up the Wardwán

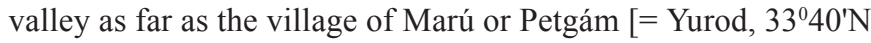
$\left.75^{\circ} 44^{\prime} \mathrm{E}\right]$ which has an elevation of about 7500 feet [2300m], beyond which point I did not observe it. In the Chináb valley I saw large numbers of this species near the village of Seri or Sereri [ $=$ Siri, $33^{\circ} 19^{\prime} \mathrm{N} 76^{\circ} 03^{\prime} \mathrm{E}$ ], at an elevation a little below 9000 feet" (2750m). On 18 August 1972, during her year-long study at Melamchigaon of langurs living between 2440 to $3050 \mathrm{~m}$, Bishop (1978) sighted a troop at $4050 \mathrm{~m}$ at Routang, a high altitude pasture north of the village of Tarke Ghyang $\left(28^{\circ} 03^{\prime} \mathrm{N}\right.$ $\left.85^{\circ} 33^{\prime} \mathrm{E}\right)$, Helambu Valley, Nepal. The previous day others had seen the same troop along the higher ridges at $4250 \mathrm{~m}$. Thirty animals, including several large adult males and at least two approximately six-month old infants were counted but the minimum troop size was 50 individuals. Local herdsmen reported the troop sleeps on a ledge inaccessible to humans under an overhanging rock at $3780 \mathrm{~m}$, moving up the slopes each morning to forage as high as $4270 \mathrm{~m}$, probably at the upper limit of the Dry Alpine Scrub Zone above the $3500 \mathrm{~m}$ tree line. This troop 
usually frequented lower altitudes, possibly down to $2744 \mathrm{~m}$ (Bishop, in Oppenheimer, 1977, p. 479). In the same National Park, Green (1981, p. 80) reported Langtang Valley langurs were usually seen between 1520 and $3510 \mathrm{~m}$. Repeated sightings of one troop of up to 46 langurs indicated it ranged a distance of $17 \mathrm{~km}$ from below Ghora Tabela, $3050 \mathrm{~m}$, during winter and spring to Langtang Village, $3510 \mathrm{~m}$, between July and December. At three different localities, the furthest $8 \mathrm{~km}$ from Langtang Village, a lone adult, probably from this troop, was seen on 28 September at $4050 \mathrm{~m}$, on 3 October at $4020 \mathrm{~m}$, and on 5 October at $4120 \mathrm{~m}$, indicating an individual annual range of $25 \mathrm{~km}$ and $1070 \mathrm{~m}$ in altitude. USNM.174083 from Kishtwar (see under $S$. e. schistaceus) weighed 52lb (23.6kg). On 1 November 1898, P.H.G. Powell-Cotton collected (numbers 189-190) two adult males "by

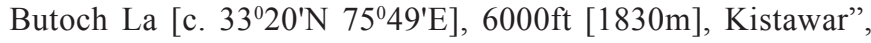
preserved as mounted skins with skulls inside at the PowellCotton Museum, Birchington, Kent. Their weights of 51 and $501 \mathrm{~b}$, respectively, show that of USNM.174083 is not excessive for this subspecies.

\section{Pelage colour variation}

See under Semnopithecus entellus schistaceus.

\section{Conclusions}

Brandon-Jones (1996) deduced that modern Asian faunal and floral distributions were moulded by at least two abrupt transitions from warm and wet to cool and dry climatic conditions probably associated with the onset ot two successive Pleistocene glaciations. The influence of the less abrupt second detectable such climatic change is most discernible in Sumatra, Indonesia. The probable scenario is that the earlier, more abrupt change (provisionally dated to about 190,000 years ago) eliminated all colobines then extant in the Indian subcontinent except for Semnopithecus johnii. The distribution of $S$. johnii contracted to its present relict extent. During the interval between the two dry periods $S$. johnii spread, managing to colonize Sri Lanka where it diverged into $S$. vetulus. The less abrupt second climatic change (possibly only about 80,000 years ago) allowed a small section of this latter population to survive in the Adam's Peak area of south-western Sri Lanka, the source of an adult male specimen (ZD.1911.9.9.1) showing a remarkable resemblance to $S$. johnii.

After the second dry period, the geographic dispersal of Semnopithecus vetulus apparently bifurcated as the gradual resumption of a more moist climate in northern Sri Lanka allowed reoccupation. One branch followed the west coast where $S . v$. nestor diverged from $S$. v. vetulus. The other moved through the centre of the island where $S$. v. philbricki diverged from $S$. v. monticola. The more abrupt break from the wet south-west to the dry south-east of Sri Lanka evidently posed a greater challenge to colonization. A more pronounced morphological shift, effectively the emergence of a new subgenus, was necessary before $S$. priam could diverge from $S$. vetulus to exploit south-east Sri Lanka. From there it reached India where dispersal along the west coast and divergence into S. entellus were encouraged by the relatively moist climate of the Malabar coast. S. priam probably only later entered the dry south-east of the Peninsula.

The dispersal routes of Semnopithecus priam and S. vetulus philbricki intersect in northern Sri Lanka without known interbreeding whereas $S$. priam and $S$. johnii are parapatric. Parapatry between $S$. entellus and $S$. johnii is likely but unconfirmed. This parapatry improbably results from habitat preference. S. e. hypoleucos occupies evergreen rainforest where $S$. johnii is absent (Ryley, 1913c, pp. 489, 492-493). Perhaps the relatively high population density of the established colobine $S$. johnii in the Western Ghats deterred $S$. priam from entering its territory. Hornaday (1885, pp. 142, 495) judged $S$. johnii the most abundant animal in the Annamalai Hills (Tamil Nadu) in 1877. He often saw over 150 a day and claimed he could easily have killed fifty a week. (Although present for about 18 weeks, mercifully he restricted his total haul to about 45.). S. johnii has evidently lost the impetus to transgress its glacially-induced geographic perimeter. Where it meets $S$. priam or $S$. entellus at that boundary they hybridize, producing the dark pelage colour of adjacent $S$. priam and $S$. e. hypoleucos populations. In the Annamalai Hills, hybridization apparently takes the form of a lone adult female $S$. johnii leaving her natal group and latching on to a $S$. priam troop (A. Kumar, A. Sharma \& M. Singh, pers. comm.).

Populations here provisionally referred to Semnopithecus priam thersites from the Tamil Nadu slopes of the Western Ghats south of the Palakkad Gap and from the north face overlooking the Gap on the Kerala side seem to have a darker hand than $S$. p. priam. This may indicate their affinity with the Sri Lankan population or may indicate interbreeding with $S$. johnii or with a dark-handed $S$. entellus population on the Kerala side. Evidence for such a population or for that matter any langurs in southern Kerala is absent. Even in June 1936 during his tenday search there for langurs, Hill (1937c) was assured of their extreme rarity and (other than at Cape Comorin) presence only in the extreme north-east of Travancore. It is provisionally concluded that $S$. $p$. thersites alone does or did occupy southern Kerala or that southern Kerala is somehow unfit for langur occupation. In central Kerala, most probably at the Gap, S. e. hypoleucos replaces $S$. $p$. thersites. Populations apparently linking the two species exist south of the Gap on the Nelliampathy Plateau and at Nagarhole (Karnataka) to the north. The Nagarhole population is unlikely to precede $S$. e. hypoleucos as it shows more affinities with $S$. e. achates.

The series of subspecies commencing with Semnopithecus entellus hypoleucos and passing through S. e. achates and $S$. e. entellus to culminate in $S$. e. anchises displays a plausible sequence of metachromic pelage colour dilution. This probably reveals their order of origin as langurs spread in phases across central India from the wetter west of the Peninsula into the drier south-east. Turning back on itself, this dispersal route is the probable explanation for the near division of $S$. e. achates into two populations. As $S$. e. anchises moves westwards it is evidently supplanting the former central section of $S$. e. achates distribution. 
A similar sequence but in this case of pelage colour saturation is displayed by the Himalayan subspecies commencing with Semnopithecus entellus hector. The evidence of probable intergration at Gorakhpur (see under S. e. hector) indicates S. e. achates as its probable antecedent. It may have parallel, rather than shared external similarities with S. e. entellus. Presumably $S$. e. hector spread along the Terai before breaking through into higher altitudes where it capitalized on the more benevolent climate to rapidly spread as $S$. e. schistaceus, and then to produce its northern offshoot $S$. e. ajax. The moist Himalayan climate and physical constraints on further dispersal are perhaps encouraging stabilization and saturation.

Roonwal (1981b, p. 36) suspected that, having evolved during the Pleistocene in the northern part of the Peninsula, Semnopithecus entellus spread south before Sri Lanka separated from the mainland in the recent, possibly prehistoric era. He suggested the preponderance of southern subspecies (he recognized ten southern and five northern ones) resulted from genetic drift in "an abundance of isolated niches among hills and impenetrable evergreen forests". Probably between the Narmada and Tapti rivers in the north-west of the Peninsula, the original backward-looped (southern) mode of tail carriage mutated into a forward-looped one. This mutation radiated over the Northern Plains where near or complete absence of physical barriers, as indicated by the relative uniformity of $S$. $e$. entellus, allowed rapid dispersal (Roonwal [1981a, p. 133] followed Pocock [1928; 1939] in including the northern section of S. e. achates in S. e. entellus). Roonwal (1981b, p. 39) believed the Himalayan and southern subspecies arose through similar processes of hill and forest isolation. Their smaller number and homogeneity indicate the recent evolution of the Himalayan ones.

Roonwal's (1981b, p. 30) discovery that, apart from the tail-tip being straight or drooped rather than normally out-curved, langurs at Bharuch $\left(21^{\circ} 42^{\prime} \mathrm{N} 72^{\circ} 58^{\prime} \mathrm{E}\right.$, Gujarat, India) exhibit a mode of tail carriage indistinguishable from the Himalayan one, belies his claim (p. 39) that these markedly differ. Roonwal et al. $(1984$, pp. 19, 22) later discovered this stance $5 \mathrm{~km}$ southeast of Arni $\left(20^{\circ} 00^{\prime} \mathrm{N} 78^{\circ} 00^{\prime} \mathrm{E}\right.$, Yavatmal District, Maharashtra). Even at Jodhpur (Rajasthan) at the western extremity of the area of Northern Plains mode of tail carriage (Roonwal, 1979a, p. 248), Roonwal and Makwana (1981, fig. 3G) illustrated a similar stance to the one at Bharuch. Some Himalayan langurs (e.g. Roonwal, 1979b, figs. 2f, h; 1984, figs. 2d, e) assume an S-shaped tail carriage distinguishable from the southern type only by the relative shortness of the distal curl. This makes the southern mode of tail carriage of the Bharuch juvenile barely exceptional but Roonwal (1981b, pp. 30, 36, pl. 1, fig. 6) attributed it to probable hybridization. Roonwal et al. (1984, p. 23) compared the two principal populations showing backward-looped and forward-looped modes of tail carriage to two parapatric species, such as Macaca mulatta and M. radiata. Semnopithecus entellus achates, however, is divided into a northern and a southern section with different modes of tail carriage which alter near Bharuch instead of at the possible geographic hiatus between these sections near Pune (Maharashtra). Further research may reveal that the Arni and Bharuch populations are directly linked to the Himalayan subspecies by a swathe of populations with similar tail carriage. This would effectively split $S$. e. achates into four tail carriage sections: southern, western, central and eastern, with the western and eastern sections being essentially identical (although the trend for the tail to hang down the flank seems more marked in the west).

Their lack of synchronicity with the external morphology discredits the implication that the boundaries between the distinct modes of tail carriage indicate hybridization between separate species. Such conclusions are certainly premature until the overall geographic distribution of tail carriage variation is more completely documented. Its resemblance to that of Trachypithecus substantiates Roonwal's (1981b, p. 36) conjecture that the backward-looped (southern) mode of tail carriage is ancestral. The trend seems to be for the rigidity of the distal part of the tail to gradually lessen as it droops from an open S-shape to an inverted U-shape and then swings round to the front. The Arni, Baruch and Himalayan populations retain a relative rigidity in keeping the distal section of the tail suspended above the back, while in other Northern Plains populations the rigidity decreases. This interpretation is compatible with the view that tail carriage has transformed as the langur has dispersed northwards from its origins in southern Sri Lanka. It indicates that the vanguard of a langur dispersal through central Madhya Pradesh reached the Himalaya before its flanks headed west to Rajasthan and east to West Bengal.

The other subspecies which seems to display more than one mode of tail carriage is Semnopithecus entellus anchises. In this case both the distribution of the subspecies and the distribution of its tail carriage variation is less confidently documented. Were it not for the finding of three modes of tail carriage near Arni, the above analysis of its phylogeny might encourage the view that the whole subspecies displays the northern mode of tail carriage and that the contrary record from the shores of Lake Lonar (c. $19^{0} 58^{\prime} \mathrm{N} 76^{\circ} 40^{\prime} \mathrm{E}$, Maharashtra) is an error. Possibly S. e. anchises retains the northern mode of tail carriage in the eastern area of its distribution which were presumably never occupied by $S$. e. achates, and has more than one mode where it has partially displaced and interbred with it in the west. This interpretation is perhaps corroborated by the similarity at Arni and Pune (Maharashtra) of the abnormal central angular bend in the backward loop of the southern mode of tail carriage (Roonwal et al., 1984, p. 23) (For details of these and other available tail carriage locality records, see Appendix).

\section{REFERENCES}

Abdulali, H. (1952). Unpublished letter (with monochrome photographs) to R.W. Hayman, 27 August 1952. Department of Zoology (Mammal Section) archives, Natural History Museum, London.

[Ali, S., S.B. Setna and H. Santapau]. (1953). A local variety of the Nilgiri langoor. Journal of the Bombay Natural History Society 51: 720. [Published on 19 September 1953, see foot of p. 764.]

Anderson, J. (1879). Anatomical and Zoological Researches: comprising an account of the zoological results of the two expeditions to Western Yunnan in 1868 and 1875; and a monograph of the two Cetacean genera, Platanista and Orcella, vol. 1 - Text. Quaritch, London. 
[Published in 1879, see corrigenda on p. xi.]

Anderson, J. (1881). Catalogue of Mammalia in the Indian Museum, Calcutta, part 1. Trustees of the Indian Museum, Calcutta.

Baikie, R. (1834). Observations on the Neilgherries, including an account of their Topography, Climate, Soil and Productions, and of the Effects of the Climate on the European Constitution. Baptist Mission Press, Calcutta.

Balakrishnan, M. and P.S. Easa. (1986). Habitat preferences of the larger mammals in the Parambikulam Wildlife Sanctuary, Kerala, India. Biological Conservation 37: 191-200.

Baptista, N.A. (1930). Survey of Eastern Ghats - Mammals. Unpublished Report, Department of Zoology (Mammal Section) archives, Natural History Museum, London.

Bhargava, R.N. (1984). Primates in the Indian Desert (the Hanuman Langur, Presbytis entellus, and the Rhesus Macaque, Macaca mulatta), pp. 41-45. In: Roonwal, M.L., S.M. Mohnot and N.S. Rathore (Eds.). Current Primate Researches. Department of Zoology, University of Jodhpur, Jodhpur.

Bishop, N.H. (1978). Langurs living at high altitudes. Journal of the Bombay Natural History Society 74: 518-520. [Published on 27 November 1978, see list of contents.]

Bishop, N.H. (1979). Himalayan langurs: temperate colobines. Journal of Human Evolution 8: 251-281.

Blanford, W.T. (1888a). Critical notes on the nomenclature of Indian mammals. Proceedings of the Zoological Society of London 1887: 620638. [Published on 1 April 1888, see wrapper.]

Blanford, W.T. (1888b). The Fauna of British India, including Ceylon and Burma: Mammalia. Taylor and Francis, London. [Published in late June 1888, see preface to Part 2.]

Blyth, E. (1841). Report for the month of September, by the curator. Journal of the Asiatic Society of Bengal 10: 836-842.

Blyth, E. (1843a). [Report from the curator for the month of July, 1842.] Journal of the Asiatic Society of Bengal 11: 865-891.

Blyth, E. (1843b). [Postscript to] a memorandum from the Zoological curator... on some new monkies, birds, \&c. on the table. Journal of the Asiatic Society of Bengal 12: 167-182*. [The asterisk indicates duplicate pagination.]

Blyth, E. (1844a). [Correspondence] to Richard Taylor, Esq. Annals and Magazine of Natural History (1)13: 312-313.

Blyth, E. (1844b). Notices of various Mammalia, with descriptions of many new species. Journal of the Asiatic Society of Bengal 13: 463494.

[Blyth, E.] (1845). Contents of large case, No. 1. Corrected list of April $8^{\text {th }}[18] 45$. Rec[eive]d Nov. $10^{\text {th }} 1845$. Manuscript catalogues and memoranda of the zoological collections in the India Museum transferred to the British Museum in 1879, Zoology Library, Natural History Museum, London. [Bound into quarto volume as p. 153 in pencil pagination.]

Blyth, E. (1847a). Some further notice of the species of wild sheep. Journal of the Asiatic Society of Bengal 16: 350-366.

Blyth, E. (1847b). Supplementary report of the curator of the Zoological Department. Journal of the Asiatic Society of Bengal 16: 728-737.

Blyth, E. (1847c). Critical remarks upon Mr. J.E. Gray's published catalogue of the specimens of Mammalia and birds presented by B.H. Hodgson, Esq. to the British Museum. Annals and Magazine of Natural History (1)20: 313-323.

Blyth, E. (1848a). Report of curator, Zoological Department. Journal of the Asiatic Society of Bengal 16: 1271-1276. [This report is part of the Proceedings of the Asiatic Society of Bengal for December 1847 and, according to a holograph insert by C.D. Sherborn at the front of the British Museum (Natural History) copy of the volume, was published on 7 January 1848.]

Blyth, E. (1848b). Report of curator, Zoological Department. Journal of the Asiatic Society of Bengal 17: 82-85.

Blyth, E. (1848c). Report of curator, Zoological Department. Journal of the Asiatic Society of Bengal 17: 237-255.

Blyth, E. (1851). Report on the Mammalia and more remarkable species of birds inhabiting Ceylon. Journal of the Asiatic Society of Bengal 28: $153-185$.

Blyth, E. (1859). Report of curator, Zoological Department, for February to May meetings, 1859. Journal of the Asiatic Society of Bengal 20: 271-298.

Blyth, E. (1863). Catalogue of the Mammalia in the Museum of the Asiatic Society of Bengal. Asiatic Society of Bengal, Calcutta.

Bonhote, J.L. (1901). On the mammals collected during the "Skeat Expedition" to the Malay Peninsula, 1899-1900. Proceedings of the Zoological Society of London 1900: 869-883. [Published on 1 April 1901, see wrapper.]

Bourns, F.S. and D.C. Worcester (1894). Preliminary notes on the birds and mammals collected by the Menage Scientific Expedition to the Philippine Islands. Occasional Papers. Minnesota Academy of Natural Sciences 1(1): 1-64.

Brandon-Jones, D. (1984). Colobus and leaf monkeys, pp. 398-408. In: Macdonald, D. (Ed.). The Encyclopaedia of Mammals, Vol. 1. Allen and Unwin, London.

Brandon-Jones, D. (1993). The taxonomic affinities of the Mentawai Islands sureli, Presbytis potenziani (Bonaparte, 1856) (Mammalia: Primates: Cercopithecidae). Raffles Bulletin of Zoology 41: 331-357.

Brandon-Jones, D. (1995). A revision of the Asian pied leaf monkeys (Mammalia: Cercopithecidae: superspecies Semnopithecus auratus), with a description of a new subspecies. Raffles Bulletin of Zoology 43: 3-43. Brandon-Jones, D. (1996). The Asian Colobinae (Mammalia: Cercopithecidae) as indicators of Quaternary climatic change. Biological Journal of the Linnean Society 59: 327-350.

Brandon-Jones, D. (1999). A revision of the surelis, genus Presbytis Eschscholtz, 1821 (sensu stricto) (Mammalia: Cercopithecidae). PhD Thesis. University of London, England.

Brandon-Jones, D. (2001). Colobus and leaf monkeys. In: Macdonald, D. (Ed.). The New Encyclopedia of Mammals, pp. 380-391. Oxford University Press, Oxford.

Brandon-Jones, D., A.A. Eudey, T. Geissmann, C.P. Groves, D.J. Melnick, J.C. Morales, M. Shekelle and C.-B. Stewart (2004). Asian primate classification. International Journal of Primatology 25: 97-164.

Buffon, G.L.L. de. (1789). Histoire Naturelle Générale et Particulière, servant de suite à l'Histoire des Animaux Quadrupèdes, suppl. vol. 7. L'Imprimerie Royale, Paris.

Butler, J. (1875). Rough notes on the Angámi Nágás and their language. Journal of the Asiatic Society of Bengal 45(1): 307-346.

Byrne, P. (1979). Exploring Nepal's rivers. Explorers Journal 57: 6873.

Byrne, P. (1982). The Rara Expedition. Explorers Journal 60: 114121.

Cantor, T. (1846). Catalogue of Mammalia inhabiting the Malayan Peninsula and islands, collected or observed by Theodore Cantor, M.D., Bengal Medical Service. Journal of the Asiatic Society of Bengal 15: 171-203.

Chalise, M.K. (1995). Comparative study of feeding ecology and behavior of male and female langurs (Presbytis entellus). PhD Thesis. Tribhuvan University, Nepal.

Chesemore, D.L. (1970). Notes on the mammals of southern Nepal. Journal of Mammalogy 51: 162-166.

Corbet, G.B. (1992). [Sections other than on Chiroptera.] In: Corbet, G.B. and J.E. Hill. The Mammals of the Indomalayan Region: a systematic review. Oxford University Press, Oxford. [For authorship, see preface and p. 12.]

Cuvier, F. (1825a). Entelle vieux. In: Geoffroy Saint-Hilaire, [É.] and F. Cuvier. Histoire Naturelle des Mammifères, avec des figures originales, coloriées, dessinées d'après des animaux vivans, vol. 3, part 47. Belin, Paris.

Cuvier, F. (1825b). Croo. In: Geoffroy Saint-Hilaire, [É.] and F. Cuvier. Histoire Naturelle des Mammifères, avec des figures originales, coloriées, dessinées d'après des animaux vivans, vol. 3, part 49. Belin, Paris.

Dalgliesh, G. (1903). Notes and observations on the mammals observed in the Darbhanga district, Tirhoot, Bengal. Zoologist (4)7: 94-99.

Dammerman, K.W. (1926). The fauna of Durian and the Rhio-Lingga Archipelago. Treubia 8: 281-326.

de Lacaze, A. (1856). Duvaucel (Alfred). In: Nouvelle Biographie Générale depuis les Temps les plus Recules jusqu'a nos Jours, vol. 15. 
Firmin Didot Frères, Paris.

Desmarest, A.G. (1822). [Encyclopédie Methodique. Histoire Naturelle.] Mammalogie ou Description des Espèces de Mammifères, part 2, supplément. Agasse, Paris.

Desmarest, [A.G.] and [J.-J.] Virey (1817). Guenon. In: Nouveau Dictionnaire d'Histoire Naturelle, vol. 13, pp. 574-586. Deterville, Paris. [For authorship, see p. 586.]

Dixon, R.M. (1894). The strychnine tree. Journal of the Bombay Natural History Society 9: 102-105. [Published on 1 September 1894, see wrapper.]

Dodsworth, P.T.L. (1914). Notes on some mammals found in the Simla District, the Simla Hill States, and Kalka and adjacent country. Journal of the Bombay Natural History Society 22: 726-748. [Published on 31 March 1914, see wrapper.]

Dollman, [J.G.] (1913). In: Ryley, K.V. Scientific results from the Mammal Survey. 5E. Notes on the langurs (Presbytis) of central and southern India. Journal of the Bombay Natural History Society 22: 438443. [Published on 20 December 1913, see wrapper.]

Dufresne. (1797). Sur une nouvelle espèce de singe. Bulletin des Sciences par la Société Philomatique de Paris 2(7): 49. [Dufresne's surname was prefixed with "Cit.", evidently an abbreviation for "Citoyen" (meaning "Citizen", the French Revolutionary mode of address). Geoffroy (1843a, p. 586) prefixed it with "M.", probably an abbreviation for "Monsieur", and recorded his appointment as "aide-naturaliste et chef du laboratoire de zoologie, peu de temps après l'organisation du Muséum d'histoire Naturelle", c. 1793. His true initial is untraced.]

Duncan, F.M. (1937). On the dates of publication of the Society's 'Proceedings,' 1859-1926. Proceedings of the Zoological Society of London (A) 107: 71-84.

Dussumier, J.-J. (1828). Lettre de M. Dussumier à MM. les ProfesseursAdministrateurs du Muséum. Mémoires du Muséum d'Histoire Naturelle, Paris 15: 377-384.

Duvernoy, G.L. (1835). Quelques observations sur le canal alimentaire des semnopithèques, et description d'un sphincter oesophagien du diaphragme dans ces animaux et dans plusiers autres genres de singes. Mémoires de la Société du Muséum d'Histoire Naturelle de Strasbourg 2(1): $1-8,1 \mathrm{pl}$.

Ellerman, J.R. and T.C.S. Morrison-Scott (1951). Checklist of Palaearctic and Indian Mammals, 1758-1946. Trustees of the British Museum, London.

Ellerman, J.R. and T.C.S. Morrison-Scott (1966). Checklist of Palaearctic and Indian Mammals, 1758-1946, 2nd edition. Trustees of the British Museum (Natural History), London.

Elliot, D.G. (1909). Descriptions of apparently new species and subspecies of monkeys of the genera Callicebus, Lagothrix, Papio, Pithecus, Cercopithecus, Erythrocebus and Presbytis. Annals and Magazine of Natural History (8)4: 244-274.

Elliot, W. (1839). A catalogue of the species of Mammalia found in the Southern Mahratta Country; with their synonymes in the native languages in use there. Madras Journal of Literature and Science 10: 92-108, 207-233.

Feng Z., Cai G. and Zheng C. (1986). The Mammals of Xizang. Science Press, Beijing. 411pp.

Fiedler, W. (1956). Übersicht über das System der Primates, pp. 1-266. In: Hofer, H., A.H. Schultz and D. Starck (Eds.) Primatologia, Vol. 1. Karger, Basel.

Fischer, J.B. (1829). Synopsis Mammalium. Cotta, Stuttgart.

Fletcher, F.W.F. (1911). Sport on the Nilgiris and in Wynaad. Macmillan and Co., London.

Flower, S.S. (1914). Report on a zoological mission to India in 1913. (Publication no. 26). Government Press, Cairo.

Fooden, J. (1981). Taxonomy and evolution of the sinica group of macaques: 2. Species and subspecies accounts of the Indian bonnet macaque, Macaca radiata. Fieldiana Zoology (new ser.) 9: v-vii, 1-52. Fooden, J. (2000). Systematic review of the rhesus macaque, Macaca mulatta (Zimmermann, 1780). Fieldiana Zoology (new ser.) 96: i-vi, 1180 .

Fry, T.B. (1925). Bombay Natural History Society's Mammal Survey of India, Burmah and Ceylon. Report No. 37(a). Nepal. Journal of the
Bombay Natural History Society 30: 525-530. [Published on 30 June 1925, see wrapper.]

Gaston, A.J., P.J. Garson and M.L. Hunter, Jr. (1983). The status and conservation of forest wildlife in Himachal Pradesh, Western Himalayas. Biological Conservation 27: 291-314.

Geoffroy Saint-Hilaire, I. (1830). Description de plusieurs espèces nouvelles de singes, appartenant aux genres Semnopithèque et Macaque. Bulletin des Sciences Naturelles et de Géologie 22: 317-318.

Geoffroy Saint-Hilaire, I. (1831). Observations et recherches spéciales sur les mammifères. In: Bélanger, C. Voyage aux IndesOrientales...pendant les Années 1825[-]1829. Bertrand, Paris, pp. 17160.

Geoffroy Saint-Hilaire, I. (1842). Sur les singes de 1'ancien monde, spécialement sur les genres Gibbon et Semnopithèques (Extrait). Compte Rendu Hebdomadaire des Séances de l'Académie des Sciences, Paris 15: 716-720. [Published on 10 October 1842, according to pencil note (by C.D. Sherborn) in NHM copy of Geoffroy (1843a, p. 538).]

Geoffroy Saint-Hilaire, I. (1843a). Descriptions des mammifères nouveaux ou imparfaitement connus de la collection du Muséum d'Histoire Naturelle, et remarques sur la classification et les caractères des mammifères. Premier mémoire. Famille des singes. Archives $d u$ Muséum d'Histoire Naturelle, Paris 2, 485-592, 6 plates.

Geoffroy Saint-Hilaire, I. (1843b). Voyage dans l'Inde, par Victor Jacquemont, pendant les années 1828 a 1832, vol. 4: Descriptions des collections. Zoologies. Mammifères. L'Institut de France, Paris. [Published after April 1843, see Sherborn and Woodward (1901, p. 334).] Geoffroy Saint-Hilaire, I. (1851a). Catalogue méthodique de la collection des mammifères, de la collection des oiseaux et des collections annexes du Muséum d'Histoire Naturelle de Paris. Première partie. Mammifères. Catalogue des primates. Gide et Baudry, Paris.

Geoffroy Saint-Hilaire, I. (1851b). Descriptions des mammifères nouveaux ou imparfaitement connus de la collection du Muséum d'Histoire Naturelle et remarques sur la classification et les caractères des mammifères. Troisième mémoire. Famille des singes; supplément. Archives du Muséum d'Histoire Naturelle, Paris 5: 529-584.

Gittins, S.P. and A.W. Akonda (1982). What survives in Bangladesh? Oryx 16: 275-281.

Gray, J.E. (1843). List of the Specimens of Mammalia in the Collection of the British Museum. British Museum, London.

Gray, J.E. (1847). Catalogue of the specimens and drawings of Mammalia and birds of Nepal and Thibet, presented by B. H. Hodgson, Esq. to the British Museum. Trustees of the British Museum, London. [The preface is dated "December 10th, 1846", and the date of publication is "9 Jan. 1847, fide Sherborn" (Holograph by M.R.O. Thomas in NHM Mammal Section copy).]

Gray, J.E. (1863). Catalogue of the specimens and drawings of Mammalia and birds of Nepal and Thibet, presented by B. H. Hodgson, Esq. to the British Museum. (2 ${ }^{\text {nd }}$ edition). Trustees of the British Museum, London.

Green, M.J.B. (1981). A checklist and some notes concerning the mammals of the Langtang National Park, Nepal. Journal of the Bombay Natural History Society 78: 77-87. [Published on 15 May 1981, see list of contents.]

Groves, C.P. (1989). A theory of human and primate evolution. Oxford University Press, Oxford.

Groves, C.P. (1993). Order Primates, pp. 243-277. In: Wilson, D.E. and D.M. Reeder (Eds.) Mammal Species of the World: A Taxonomic and Geographic Reference. $2^{\text {nd }}$ edition. Smithsonian Institution Press, Washington and London.

Groves, C.P. (2001). Primate Taxonomy. Smithsonian Institution Press, Washington, D.C.

Gupta, K.K. (1974). Fauna of Orang Wild Life Reserve. Rhino-Journal of the Kaziranga Wild Life Society 2: 20-30.

Hassinger, J.D. (1973). A survey of the mammals of Afghanistan resulting from the 1965 Street Expedition (excluding bats). Fieldiana Zoology 60: 1-195.

Heape, W. (1895). The menstruation of Semnopithecus entellus. Philosophical Transactions of the Royal Society of London (B)185: 411-471. [Published in 1895, see wrapper.] 
Hill, W.C.O. (1934). A monograph on the purple-faced leaf-monkeys (Pithecus vetulus). Ceylon Journal of Science (B)19: 23-88.

Hill, W.C.O. (1936). Supplementary observations on purple-faced leafmonkeys (genus Kasi). Ceylon Journal of Science (B)20: 115-133.

Hill, W.C.O. (1937a). The type of Semnopithecus thersites Blyth. Ceylon Journal of Science (B)20: 207-209.

Hill, W.C.O. (1937b). The pre-natal development of the grey langur, Semnopithecus priam thersites. Ceylon Journal of Science (B)20: 211251.

Hill, W.C.O. (1937c). The primates of Travancore. Proceedings of the Zoological Society of London (B)107: 205-216. [Published on 15 July 1937, see wrapper of succeeding part.]

Hill, W.C.O. (1939). An annotated systematic list of the leaf-monkeys. Ceylon Journal of Science (B)21: 277-305.

Hinton, M.A.C. and T.B. Fry (1923). Bombay Natural History Society's Mammal Survey of India, Burma and Ceylon. Report No. 37 , Nepal. Journal of the Bombay Natural History Society 29: 399-428. [Published on 25 August 1923, see wrapper.]

Hodgson, B.H. (1832). On the Mammalia of Nepal. Journal of the Asiatic Society of Bengal 1: 335-349.

Hodgson, B.H. (1836a). Illustrations of Nipalese zoology. Journal of the Asiatic Society of Bengal 4: 521-525.

Hodgson, B.H. (1836b). Synoptical descriptions of sundry new animals. Journal of the Asiatic Society of Bengal 5: 231-238.

Hodgson, B.H. (1841). Three new species of monkey; with remarks on the genera Semnopithecus et Macacus. Journal of the Asiatic Society of Bengal 9: 1211-1213. [Published after February 1841: foot of paper dated "March, 1841".]

Hodgson, B.H. (1844). Classified catalogue of mammals of Nepal (corrected to end of 1841, first printed in 1832). Calcutta Journal of Natural History 4: 284-294. [A footnote to the title states: Reprinted from the Proceedings of the Zoological Society, with corrections and additions up to the end of 1843 by Mr. Hodgson. - J. M(cClelland, editor).]

Hohmann, G. (1988). Analysis of loud calls provides new evidence for hybridisation between two Asian leaf monkeys (Presbytis johnii, P. entellus). Folia Primatologica 51: 209-213.

Hohmann, G. and M. Herzog (1985). Die braunen Languren Südindiens. Zeitschrift des Kölner Zoo 28: 37-41.

Hornaday, W.T. (1885). Two Years in the Jungle: the Experiences of a Hunter and Naturalist in India, Ceylon, the Malay Peninsula and Borneo. Kegan Paul, Trench and Co., London.

Horsfield, T. (1851). A Catalogue of the Mammalia in the Museum of the Hon. East-India Company. J. and H. Cox, London.

Hrdy, S.B. (1977). The Langurs of Abu: Female and Male Strategies of Reproduction. Harvard University Press, Cambridge, MA.

Hughes, T.H. (1884). An incident in the habits of the Semnopithecus Entellus, the common hanuman monkey. Proceedings of the Asiatic Society of Bengal 1884: 147-150.

Husson, A.M. and L.B. Holthuis (1955). The dates of publication of "Verhandelingen over de Natuurlijke Geschiedenis der Nederlandsche overzeesche bezittingen" edited by C.J. Temminck. Zoologische Mededeelingen, Leiden 34: 17-24.

Hutton, A.F. (1950). Notes on the snakes and mammals of the High Wavy Mountains, Madura District, S. India. Journal of the Bombay Natural History Society 48: 681-694. [Published on 31 January 1950, see foot of p. 816.]

Hutton, T. (1837). Journal of a trip to the Burenda Pass in 1836. Journal of the Asiatic Society of Bengal 6: 901-938.

Hutton, T. (1868). On the geographical range of Semnopithecus entellus. Proceedings of the Zoological Society of London 1867: 944-952. [Published in April 1868, see Duncan (1937, p. 72).]

Jacquemont, V. (1841). Voyage dans l'Inde, pendant les années 1828 a 1832, Journal, Vol. 1. Guizot, Paris.

Jay, P. (1965). The common langur of north India, pp. 197-249. In: DeVore, I. (Ed.). Primate Behavior: Field Studies of Monkeys and Apes. Holt, Rinehart and Winston, New York.

Jentink, F.A. (1887). Catalogue ostéologique des mammifères. Muséum d'Histoire Naturelle des Pays-Bas. vol. 9. 360pp., 12 pls.
Jentink, F.A. (1892). Catalogue systématique des mammifères (singes, carnivores, ruminants, pachydermes, sirènes et cétacés). Muséum d'Histoire Naturelle des Pays-Bas, vol. 11. 219pp.

Jerdon, T.C. (1867). The Mammals of India; a Natural History of all the Animals known to inhabit Continental India. Thomason, Roorkee. John, [C.S.] (1795). Beschreibung einiger Affen aus Kasi im nördlichen Bengalen, vom Missionarius John zu Trankenbar. Neue Schriften. Gesellschaft Naturforschender Freunde zu Berlin 1: 211-218.

John, [C.S.] (1799). Bemerkungen bey einer Gesundheits-Reise von Tranquebar nach Tanschaur, Tirutschinapalli und Madras im Februar zum May 1795. Naturforscher 28: 106-117.

Johnsingh, A.J.T. (1974). Mudaliar Ootu - a last stronghold for the rare Nilgiri tahr. Journal of the Bombay Natural History Society 70: 376-377. [Published on 15 February 1974, see list of contents.]

Johnson (1839). Indian Field Sports. [Not seen, reference from Hutton (1868).]

Kankane, P.L. (1984). Studies on the hanuman langur, Presbytis entellus, at the Madhav National Park, Shivpuri (Madhya Pradesh, India), pp. 23-31. In: Roonwal, M.L., S.M. Mohnot and N.S. Rathore (Eds.). Current Primate Researches. Department of Zoology, University of Jodhpur, Jodhpur.

Kelaart, E.F. (1850). List of Mammalia of Ceylon observed or collected in Ceylon. Journal of the Ceylon Branch of the Royal Asiatic Society 2: 201-206.

Kelaart, E.F. (1853). Prodromus Faunae Zeylanicae; being Contributions to the Zoology of Ceylon. Observer Press, Colombo. [Published after December 1852, see p. 55.]

Khajuria, H. (1956a). Catalogue of mammals in the Indian Museum (Zool. Surv.). III. Primates: Colobidae. Records of the Indian Museum 52: 195-220. [Published on 25 April 1956, see foot of p. 414.]

Khajuria, H. (1956b). The leaf monkeys of Kashmir Valley. Journal of the Bombay Natural History Society 53: 463-465. [Published on 30 May 1956, see foot of p. 514.]

Khan, M.A.R. (1984). Ecology and conservation of the common langur, Presbytis entellus, in Bangladesh, pp. 33-39. In: Roonwal, M.L., S.M. Mohnot and N.S. Rathore (Eds.). Current Primate Researches. Department of Zoology, University of Jodhpur, Jodhpur.

Kinloch, A.P. (1923). The larger mammals of the Nelliampathy Hills. Journal of the Bombay Natural History Society 29: 552-554. [Published on 25 August 1923, see wrapper.]

Krishnan, M. (1972). An ecological survey of the larger mammals of peninsular India. Journal of the Bombay Natural History Society 68: 503-555. [Published on 26 February 1972, see list of contents.]

Kuhn, H.-J. (1967). Zur Systematik der Cercopithecidae. In: Starck, D., R. Schneider and H.-J. Kuhn (eds.). Progress in Primatology. First Congress of the International Primatological Society, Frankfurt am Main, 1966, pp. 25-46. Fischer, Stuttgart.

Kullman, E. (1965). Die Säugetiere Afghanistans. I. Carnivora, Artiodactyla, Primates. Science Quarterly Journal of the Faculty of Science, Kabul, pp. 1-17. [Not seen, reference from Hassinger (1973) and Naumann \& Nogge (1973).]

Kurup, G.U. (1965). On a collection of mammals from Assam and Uttar Pradesh. Journal of the Bengal Natural History Society 33: 185209.

Lahan, P. and R.N. Sonowal (1974). Kaziranga Wild Life Sanctuary, Assam: a brief description and report on the census of large animals (March 1972). Journal of the Bombay Natural History Society 70: 245278. [Published on 15 February 1974, see list of contents.]

Laissus, Y. (1973). Note sur les voyages de Jean-Jacques Dussumier (1792-1883). Annales de la Société des Sciences Naturelles de la Charente-Maritime 5: 387-406.

Laws, J.W. and J.V.H. Laws (1984). Social interactions among adult male langurs (Presbytis entellus) at Rajaji Wildlife Sanctuary. International Journal of Primatology 5: 31-50.

Layard, E.L. (1850). Sketches in the natural history of Ceylon, part 1. Mammalia. Journal of the Ceylon Branch of the Royal Asiatic Society 2: 62-73.

Leschenault de la Tour, [J.B.] (1823). Relation abrégée d'un voyage aux Indes orientales (lue à l'Academie des Sciences, le 9 septembre 
1822). Mémoires du Muséum d'Histoire Naturelle, Paris 9: 245-274. Lindsay, H.M. (1926a). Bombay Natural History Society’s Mammal Survey of India, Burma and Ceylon. Report No. 43, Nelliampathy Plateau and Palni Hills. Journal of the Bombay Natural History Society 31: 591597. [Published on 1 November 1926, see wrapper.]

Lindsay, H.M. (1926b). Bombay Natural History Society's Mammal Survey of India, Burma and Ceylon. Report No. 44, Kangra and Chamba. Journal of the Bombay Natural History Society 31: 597-606. [Published on 1 November 1926, see wrapper.]

Lydekker, R. (1877). Notes on the mammalian fauna of the Wardwán and upper Chináb valleys. Journal of the Asiatic Society of Bengal 46(2): 283-288.

Malhotra, Y.R. and D.N. Sahi (1982). A population survey of nonhuman primates in some parts of Jammu province ( $\mathrm{J} \& \mathrm{~K}$ State), India. Tigerpaper 9(1): 24-27.

Martin, W.C.L. (1838). A monograph of the genus Semnopithecus, Magazine of Natural History (new ser.)2: 320-326, 434-441.

Martin, W.C.L. (1840). A General Introduction to the Natural History of Mammiferous Animals, with a particular view of the Physical History of Man, and the more closely allied genera of the order Quadrumana, or monkeys. Wright and Co., London. [According to Geoffroy (1843a, p. 538) and most subsequent authors it was published in 1841, but Blyth (1843b, p. 169) reported its discontinuation "(from the failure of the publishers, in 1840,) after the ninth number, which contains an account of the group under consideration" (Semnopithecus).]

McCann, C. (1933). Observations on some of the Indian langurs. Journal of the Bombay Natural History Society 36: 618-628. [Published on 15 August 1933, see wrapper.]

McMaster, A.C. (1870). Notes on Jerdon's Mammals of India. Higginbotham and Co., Madras.

[Millard, W.S., R.A. Spence and N.B. Kinnear] (1909). Proceedings of the meeting held on $24^{\text {th }}$ July 1909. Journal of the Bombay Natural History Society 19: 548-550. [Published on 15 August 1909, see wrapper.] Molur, S., D. Brandon-Jones, W. Dittus, A. Eudey, A. Kumar, M. Singh, M.M. Feeroz, M. Chalise, P. Priya and S. Walker (Eds.) (2003). Status of South Asian Primates: Conservation Assessment and Management Plan (C.A.M.P.) Workshop Report. Zoo Outreach Organisation/CBSG-South Asia, Coimbatore, India, viii+432 pp.

Mukherjee, R.P., S. Chaudhuri and A. Murmu (1995). Population survey of south-Asian non-human primates in and around Darjeeling. Primate Report 41: 23-32.

Müller, S. and H. Schlegel (1841). Monographisch overzigt van het geslacht Semnopithecus. In: Temminck, C.J. (ed.). Verhandelingen over de Natuurlijke Geschiedenis der Nederlandsche overzeesche bezittingen: Zoologie. Mammalia, pp. 57-84. van den Koning, Leiden. [Geoffroy (1843b, p. 17, footnote) gave January 1842 as the date of publication, but Husson and Holthuis (1955) specified it as 11 October 1841.]

Napier, J.R. and P.H. Napier (1967). A Handbook of Living Primates. Academic Press, London.

Napier, P.H. (1985). Catalogue of Primates in the British Museum (Natural History) and elsewhere in the British Isles, part 3: family Cercopithecidae, subfamily Colobinae. British Museum (Natural History), London, $\mathrm{x}+111 \mathrm{pp}$.

Naumann, C. and G. Nogge (1973). Die Großsäuger Afghanistans. Zeitschrift des Kölner Zoo 16: 79-93.

Nawaz, M. (1983). Natural Reserves in Pakistan. Tigerpaper 10(2): 16.

Nolte, A. (1956). Field observations on the daily routine and social behaviour of common Indian monkeys, with special reference to the bonnet monkey (Macaca radiata Geoffroy). Journal of the Bombay Natural History Society 53: 177-184. [Published on 20 January 1956, see foot of p. 314.]

Nurse, C.G. (1900). Sport and natural history in northern Gujarat. Journal of the Bombay Natural History Society 13: 337-342. [Published on 29 July 1900, see wrapper.]

Oates, J.F. (1979). Comments on the geographical distribution and status of the South Indian black leaf-monkey (Presbytis johnii). Mammalia 43: 485-493.

Oates, J.F. (1982). Coat colour aberrations in Presbytis johnii: A founder effect? Primates 23: 307-311.

Oates, J.F., A.G. Davies and E. Delson (1994). The diversity of living colobines, pp. 45-73. In: Davies, A.G. and J.F. Oates (Eds.). Colobine Monkeys: Their Ecology, Behaviour and Evolution. Cambridge University Press, Cambridge.

Oboussier, H. and G.A.v. Maydell (1960). Zur Kenntnis von Presbytis entellus (Dufresnes 1797): Ergebnisse der Deutschen Indien-Expedition 1955-57. Zoologischer Anzeiger 164: 141-154.

Ogilby, W. (1838). The menageries. The natural history of monkeys, opposums and lemurs. Library of Entertaining Knowledge. Knight, London.

Ogilby, W. (1840a). Memoir on the mammalogy of the Himalayas. Madras Journal of Literature and Science 12: 139-171.

Ogilby, W. (1840b). Memoir on the mammalogy of the Himalayas. In: Royle, J.F. Illustrations of the Botany and other branches of the Natural History of the Himalayan Mountains, and of the Flora of Cashmere, vol. 1. Allen and Co., London. [Pages lvi-lxxvi were published in 1840, see p. 1xxx.]

Oppenheimer, J.R. (1977). Presbytis entellus, the hanuman langur, pp. 469-512. In: Rainier, Prince and G.H. Bourne (Eds.). Primate Conservation. Academic Press, New York.

Otto, A. W. (1825). Über eine neue Affenart, den Cercopithecus (?) leucoprymnus. Nova Acta Physico-Medica 12(2): 503-518, 2 pls.

Phillips, W.W.A. (1981). Manual of the Mammals of Sri Lanka, part 2. Wildlife and Nature Protection Society of Sri Lanka [Colombo].

Pocock, R.I. (1928). The langurs, or leaf monkeys, of British India. Journal of the Bombay Natural History Society 32: 472-504. [Published on 15 January 1928, see wrapper.]

Pocock, R.I. (1931). The Mammal Survey of the Eastern Ghats. Report on the monkeys. Journal of the Bombay Natural History Society 35: 51-59. [Published on 15 June 1931, see wrapper.]

Pocock, R.I. (1939). The Fauna of British India, including Ceylon and Burma: Mammalia - Vol. I. Primates and Carnivora (in part). Taylor and Francis, London.

Poirier, F.E. (1970). The Nilgiri langur (Presbytis johnii) of South India, pp. 251-383. In: Rosenblum, L.A. (Ed.). Primate Behaviour: Developments in Field and Laboratory Research, Vol. 1. Academic Press, New York and London.

Prakash, I. (1956). A list of the mammals of the Rajasthan Desert. Journal of the Bengal Natural History Society 28: 1-7.

Prakash, I. (1960). Checklist of the mammals of Rajasthan Desert. University of Rajasthan Studies, Biological Sciences 4: 30-56.

Prakash, I. (1962). Group organization, sexual behaviour and breeding season of certain Indian monkeys. Japanese Journal of Ecology 12: 8386.

Prinsep, C.C. (1885). Record of Services of the Honourable East India Company's Civil Servants in the Madras Presidency. From 1741 to 1858. Trübner and Co., London.

Rahaman, H. (1974). The langurs of the Gir Sanctuary (Gujarat) - A preliminary survey. Journal of the Bombay Natural History Society 70: 295-314. [Published on 15 February 1974, see list of contents.]

Raverty, H.G. (1859). Notes on Káfiristán. Journal of the Asiatic Society of Bengal 28: 317-368.

Reichenbach, H.G.L. (1862). Central Atlas für zoologische Gärten (Fortsetzung der vollständigsten Naturgeschicte de Affen). Lief 14-16. Affen der alten Welt. Dresden and Leipzig.

Ridgway, R. (1912). Color standards and color nomenclature. The author, Washington.

Roberts, T.J. (1977). The Mammals of Pakistan. Benn, London and Tonbridge, xxvi+361pp.

Roberts, T.J. (1997). The Mammals of Pakistan, revised edition. Oxford University Press, Karachi, xxxvi+525pp.

Robinson, H.C. (1905). Report on the Selangor Museum, 1904. Journal of the Federated Malay States Museums 1: 97-104.

Rode, P. (1938). Catalogue des types de mammifères du Muséum National d'Histoire Naturelle: Ordre des Primates, sous-ordre des simiens. Bulletin du Muséum National d'Histoire Naturelle, Paris (2)10: 202-251.

Roonwal, M.L. (1979a). Field study of geographic, subspecific and clinal variation in tail carriage in the Hanuman Langur, Presbytis entellus 
(Primates), in South Asia. Zoologischer Anzeiger, Jena 202: 235-255. Roonwal, M.L. (1979b). Field observations on distribution and tail carriage in the central Himalayan Langur, Presbytis entellus schistaceous (Primates). Proceedings of the Indian National Science Academy (B)45: 45-55.

Roonwal, M.L. (1980). Quantification of tail loop characters for clinal variations in the langur, Presbytis entullus, in Peninsular India and Ceylon (Primates). Zoologischer Anzeiger, Jena 204: 177-185.

Roonwal, M.L. (1981a). Intraspecific variation in size, proportion of body parts, and weight in the hanuman langur, Presbytis entellus (Primates), in South Asia, with remarks on subspeciation. Records of the Zoological Survey of India 79: 125-158.

Roonwal, M.L. (1981b). New field data on tail carriage in the common South Asian langur, Presbytis entellus (Primates), and its biological and evolutionary significance. Proceedings of the Indian National Science Academy (B)47: 26-40.

Roonwal, M.L. (1984). More field observations on the distribution, tail carriage, group composition, etc. in the central Himalayan langur (Presbytis entellus schistaceus) and the west Himalayan macaque (Macaca mulatta villosa) (Primates). Proceedings of the Workshop on High Altitude Entomology and Wildlife Ecology, Zoological Survey of India 305-316. [Published in 1984, according to author's holograph on reprint.] Roonwal, M.L. and S.C. Makwana (1981). Tail carriage in the hanuman langur, Presbytis entellus entellus (Primates, Cercopithecidae) in the Indian Desert. Records of the Zoological Survey of India 78: 87-100.

Roonwal, M.L. and R.S. Pirta (1984). New field data on left-right handedness of tail loop in the hanuman langur, Presbytis entellus (Primates), in South Asia. Journal of the Zoological Society of India 35: 21-28. [Published in December 1984, according to author's holograph on reprint.]

Roonwal, M.L., R.S. Pirta and S.S. Saha (1984). Geographical boundary between the northern and southern tail styles in the common South Asian langur, Presbytis entellus (Primates). Journal of the Zoological Society of India 36: 15-26.

Rowe, N. (1996). The Pictorial Guide to the Living Primates. Pogonias Press, New York.

Royle, J.F. (1833). Illustrations of the Botany and other branches of the Natural History of the Himalayan Mountains, and of the Flora of Cashmere. Allen and Co., London. [Pages 1-40 were published in September 1833, see p. lxxx.]

Ryley, K.V. (1913a). Bombay Natural History Society's Mammal Survey of India. [Report No. 9, Mysore]. Journal of the Bombay Natural History Society 22: 283-295. [Published on 30 September 1913, see wrapper.] Ryley, K.V. (1913b). Bombay Natural History Society's Mammal Survey of India. Report No. 10. [Kathiawar]. Journal of the Bombay Natural History Society 22: 464-486. [Published on 20 December 1913, see wrapper.]

Ryley, K.V. (1913c). Bombay Natural History Society’s Mammal Survey of India. Report No. 11. [Coorg]. Journal of the Bombay Natural History Society 22: 486-513. [Published on 20 December 1913, see wrapper.] Ryley, K.V. (1914a). Bombay Natural History Society’s Mammal Survey of India, Burma and Ceylon. Report No. 12. [Palanpur and Mount Abu] Journal of the Bombay Natural History Society 22: 684-699. [Published on 31 March 1914, see wrapper.]

Ryley, K.V. (1914b). Bombay Natural History Society's Mammal Survey of India. Report No. 13. [S. Ceylon]. Journal of the Bombay Natural History Society 22: 700-710. [Published on 31 March 1914, see wrapper.] Sanborn, C.C. (1932). Mammals of the Suydam Cutting Sikkim expedition. Journal of the Bombay Natural History Society 36: 181187. [Published on 15 November 1932, see wrapper.]

Schlegel, H. (1876). Muséum d'Histoire Naturelle des Pays-Bas. Revue Méthodique et critique des collections déposées dans cet établissement. Tome 7. Monographie 40: Simiae. Brill, Leiden, 356pp.

Schneider, G. (1905). Ergebnisse zoologischer Forschungsreisen in Sumatra. Erster Teil. Säugetiere (Mammalia). Zoologische Jahrbücher 23: 1-172.

Schuberg, A. (1895). Carl Semper. Arbeiten aus dem ZoologischZootomischen Institut in Würzburg 10(2): i-xxii.

Shaw, G. (1800). General Zoology or Systematic Natural History, vol.
1, part I. Mammalia. Kearsley, London.

Sherborn, C.D. and B.B. Woodward (1901). Dates of publication of the zoological and botanical portions of some French voyages. - Part II. Annals and Magazine of Natural History (7)8: 161-164; 333-336; 491494.

Sherwill, S.R. (1852). The Kurrukpoor Hills. Journal of the Asiatic Society of Bengal 21: 195-206.

Siddiqi, M.S.U. (1969). Fauna of Pakistan. Agricultural Research Council, Karachi.

Sommer, V. (2002). The holy hanuman. BBC Wildlife 20(1): 50-56.

Spillett, J.J. (1967). A report on wild life surveys in north India and southern Nepal, January-June 1966. Journal of the Bombay Natural History Society 63: 492-628. [Published on 20 July 1967, see list of contents.]

Spillett, J.J. (1968). A report on wild life surveys in south and west India, November-December 1966. Journal of the Bombay Natural History Society 65: 1-46. [Published on 31 May 1968, see list of contents.]

Sterndale, R.A. (1884). Natural History of the Mammalia of India and Ceylon. Thacker, Spink and Co., Calcutta.

Stoliczka, F. (1872). Notice of the mammals and birds inhabiting Kachh. Journal of the Asiatic Society of Bengal 41(2): 211-258.

Sugiyama, Y. (1965). Group composition, population density and some sociological observations of hanuman langurs (Presbytis entellus). Primates 5: 7-37. [Published on 7 October 1965, see Primates 16 (Suppl.): 9.]

Sugiyama, Y. (1966). Behavioral development and social structure in two troops of hanuman langurs (Presbytis entellus). Primates 6: 213247. [Published on 20 May 1966, see Primates 16 (Supp1.): 10.]

Sugiyama, Y. (1967). Social organization of hanuman langurs, pp. 221-236. In: Altmann, S.A. (Ed.). Social Communication among Primates. University of Chicago Press, Chicago and London.

Sugiyama, Y. (1976). Characteristics of the ecology of the Himalayan langurs. Journal of Human Evolution 5: 249-277.

Sykes, W.H. (1831). Catalogue of the Mammalia of Dukhun (Deccan); with observations on their habits, etc., and characters of new species. Proceedings of the Zoological Society of London 1831: 99-105. [Published on 5 August 1831, see Duncan (1937, p. 78).]

Tak, P.C. and G. Kumar (1984). Field observations on tail carriage in two primates from the Kashmir Valley, India (the langur, Presbytis entellus and the macaque, Macaca mulatta), pp. 201-206. In: Roonwal, M.L., S.M. Mohnot and N.S. Rathore (Eds.). Current Primate Researches. Department of Zoology, University of Jodhpur, Jodhpur.

Thomas, O. (1918). A selection of lectotypes of Indian mammals, from the co-types described by Hodgson, Gray, Elliot and others. Journal of the Bombay Natural History Society 25: 368-372. [Published on 15 January 1918, see wrapper.]

Thomas, O. and R.C. Wroughton (1909). On mammals from the Rhio archipelago and Malay Peninsula collected by Messrs. H.C. Robinson, C. Boden Kloss and E. Seimund, and presented to the National Museum by the Government of the Federated Malay States. Journal of the Federated Malay States Museums 4: 99-129.

Tiwari, K.K., R.K. Ghose and S. Chakraborty (1971). Notes on a collection of small mammals from Western Ghats, with remarks on the status of Rattus rufescens (Gray) and Bandicota indica malabarica (Shaw). Journal of the Bombay Natural History Society 68: 378-384. [Published on 29 November 1971, see list of contents.]

Trouessart, E.-L. (1912). Description des mammifères nouveaux ou imparfaitement connus de la collection du Muséum National d'Histoire Naturelle - Ordre des Primates; familles des Cercopithécidés. Nouvelle Archives du Muséum d'Histoire Naturelle, Paris (5)4: 267-284.

True, F.W. (1894). Notes on the mammals of Baltistan and the Vale of Kashmir, presented to the National Museum by Dr. W.L. Abbott. Proceedings of the United States National Museum 17: 1-16.

Turner, S. (1800). An Account of an Embassy to the Court of the Teshoo Lama, in Tibet; containing a narrative of a journey through Bootan, and part of Tibet. Nicol and Nicol, London.

Vogel, C. (1971). Behavioral differences of Presbytis entellus in two different habitats, pp. 41-47. In: Kummer, H. (Ed.). Proceedings of the third International Congress of Primatology, Zurich 1970, vol. 3. Karger, 
Basel.

Wagner, J.A. (1839). Die Säugthiere in Abbildungen nach der Natur mit Beschreibungen von D. Johann Christian Daniel von Schreber. Supplementband. Erste Abtheilung: Die Affen und Flederthiere. Weigel, Leipzig. [For date of publication, see Wagner (1841, p. 12)]

Wagner, [J.]A. (1841). Bericht über die Leistungen in der Naturgeschichte der Saügthiere während der beiden Jahre 1839 und 1840 Archiv für Naturgeschichte 1841(2): 1-58.

Walker, H. (1842). A catalogue of the Mammalia of Assam. Calcutta Journal of Natural History 3: 265-268.

Wangchuk, T., D.W. Inouye and M.P. Hare (2003). A new subspecies of Golden Langur (Trachypithecus geei) from Bhutan. Folia Primatologica 74: 104-108.

Webb-Peploe, C.G. (1947). Field notes on the mammals of south Tinnevelly, south India. Journal of the Bombay Natural History Society 46: 629-644. [Published on 18 August 1947, see foot of p. 746.]

Wolfe, L.D. and R. Mathur (1988). Monkeys of Jaipur, Rajasthan, India: (Macaca mulatta, Presbytis entellus). Journal of the Bombay Natural History Society 84: 534-539. [Published on 25 May 1988, see list of contents.]

Wroughton, R.C. (1912a). Bombay Natural History Society's Mammal Survey of India. [Report No. 1, East Khandesh]. Journal of the Bombay Natural History Society 21: 392-410. [Published on 31 March 1912, see wrapper.]

Wroughton, R.C. (1912b). Bombay Natural History Society's Mammal Survey of India. [Report No. 2, Berars]. Journal of the Bombay Natural History Society 21: 820-825. [Published on 30 July 1912, see wrapper.] Wroughton, R.C. (1912c). Bombay Natural History Society's Mammal Survey of India. [Report No. 4, Nimar]. Journal of the Bombay Natural History Society 21: 844-851. [Published on 30 July 1912, see wrapper.] Wroughton, R.C. (1912d). Bombay Natural History Society's Mammal Survey of India. [Report No. 5, Dharwar]. Journal of the Bombay Natural History Society 21: 1170-1195. [Published on 20 November 1912, see wrapper.]

Wroughton, R.C. (1913). Bombay Natural History Society's Mammal Survey of India. Report on collection No. 6, from Kanara. Journal of the Bombay Natural History Society 22: 29-44. [Published on 21 April 1913, see wrapper.]

Wroughton, R.C. (1914). Bombay Natural History Society's Mammal Survey of India, Burma and Ceylon. Report No. 15. [Kumaon]. Journal of the Bombay Natural History Society 23: 282-301. [Published on 20 November 1914, see wrapper.]

Wroughton, R.C. (1915a). Bombay Natural History Society's Mammal Survey of India, Burma and Ceylon. Report No. 18. [Ceylon]. Journal of the Bombay Natural History Society 24: 79-96. [Published on 30 September 1915, see wrapper.]

Wroughton, R.C. (1915b). Bombay Natural History Society's Mammal Survey of India, Burma and Ceylon. Report No. 19. [Bengal, Bihar and Orissa]. Journal of the Bombay Natural History Society 24: 96-110. [Published on 30 September 1915, see wrapper.]

Wroughton, R.C. (1916a). Bombay Natural History Society's Mammal Survey of India, Burma and Ceylon. Report No. 22. [Koyna Valley]. Journal of the Bombay Natural History Society 24: 311-316. [Published on 31 January 1916, see wrapper.]

Wroughton, R.C. (1916b). Bombay Natural History Society's Mammal Survey of India, Burma and Ceylon. Report No. 23. Sikkim and Bengal Terai. Journal of the Bombay Natural History Society 24: 468-493. [Published on 20 June 1916, see wrapper.]

Wroughton, R.C. (1918). Summary of the results from the Indian Mammal Survey of the Bombay Natural History Society. Part 1. Journal of the Bombay Natural History Society 25: 547-598. [Published on 10 June 1918, see wrapper.]

Wroughton, R.C. (1921). Bombay Natural History Society's Mammal Survey of India, Burma and Ceylon. Report No. 34. Travancore. Journal of the Bombay Natural History Society 27: 549-553. [Published on 31 March 1921, see wrapper.]

Wroughton, R.C. and K.V. Ryley (1913a). [Bombay Natural History Society's Mammal Survey of India, Burma and Ceylon. Report No. 7 , Central Provinces]. Journal of the Bombay Natural History Society 22:
45-58. [Published on 21 April 1913, see wrapper.]

Wroughton, R.C. and K.V. Ryley (1913b). [Bombay Natural History Society's Mammal Survey of India, Burma and Ceylon. Report No. 8, Vijayanagar, Bellary]. Journal of the Bombay Natural History Society 22: 58-64. [Published on 21 April 1913, see wrapper.]

Zhang Y.-P., and O.A. Ryder (1998). Mitochondrial cytochrome b gene sequences of Old World monkeys: with special reference on evolution of Asian colobines. Primates 39: 39-49.

Zhang Y., Wang S. and Quan G. (1981). On the geographical distribution of primates in China. Journal of Human Evolution 10: 215 226.

\section{ACKNOWLedgements}

I thank Sally Walker for the invitation to attend the South Asian Primate C.A.M.P., and Conservation International, Primate Conservation Inc., Appenheul Primate Park, Chester Zoo, the European Association of Zoos and Aquaria, Lincoln Park Zoo, North Carolina Zoological Park, Oklahoma City Zoo and Toronto Zoo for facilitating the workshop by funding travel, accommodation, sustenance and information resources. I warmly thank all the participants for their commitment, dedication and free exchange of information. It is unfortunately impractical to list them all, so I single out the "entellus group" - Mukesh Chalise, Jhamak B. Karki, Ajith Kumar, K.K. Ramachandran, Santosh Kumar Sahoo, Ananthakrishna Sharma and Mewa Singh - whose contributions were especially relevant to this paper. Prof. Mewa Singh and Dr. A. Sharma deserve special mention for their superlative hospitality and guidance during my short visit to the Annamalai Hills, presenting the rare opportunity to observe all four diurnal non-human primate species at close quarters on 11 March 2002. J.F. Oates communicated field observations. Rauf Ali, P.O. Nameer and Sally Walker kindly supplied invaluable colour photographs. Colin P. Groves and the late Prue Napier provided much discussion, assistance and advice. Constructive criticism from Colin Groves and Peter Grubb has much improved the manuscript. My wife, Chris prepared the map and helped with drafting some of the descriptions. I thank Miss P.D. Jenkins, Natural History Museum, London; Prof. A.E.W. Miles and Dr Caroline Grigson, Odontological Museum, Royal College of Surgeons, London; Dr Chris Smeenk, National Museum of Natural History, Leiden, the Netherlands; Dr Laurent Granjon and J. Cuisin, Museum National d'Histoire Naturelle, Paris; Dr Asad R. Rahmani and Naresh Chaturvedi, Bombay Natural History Society, Mumbai; Dr Bruce D. Patterson and William Stanley, Field Museum of Natural History, Chicago; Dr Ross D.E. MacPhee, Brian Kraatz and Bob Randall, American Museum of Natural History, New York; and Dr Richard W. Thorington, Jr., Linda K. Gordon and Jeremy Jacobs, Smithsonian Institution, Washington, DC, for facilitating access to the collections in their care; and the library staff at the Natural History Museum, London, especially Ann Datta, for assistance in seeking publications, manuscripts and maps. Jack Fooden generously provided hospitality during my visit to Chicago; Tuut and Lodie Kuenen during my visit to Leiden; Stephen and Luci Nash during my first visit to New York; and Victor and Sarah Kovner during my second visit. Financial support for the research was provided by Conservation International, thanks to a grant from the Margot Marsh Biodiversity Foundation. 
Key to the subspecies of Semnopithecus entellus and S. priam

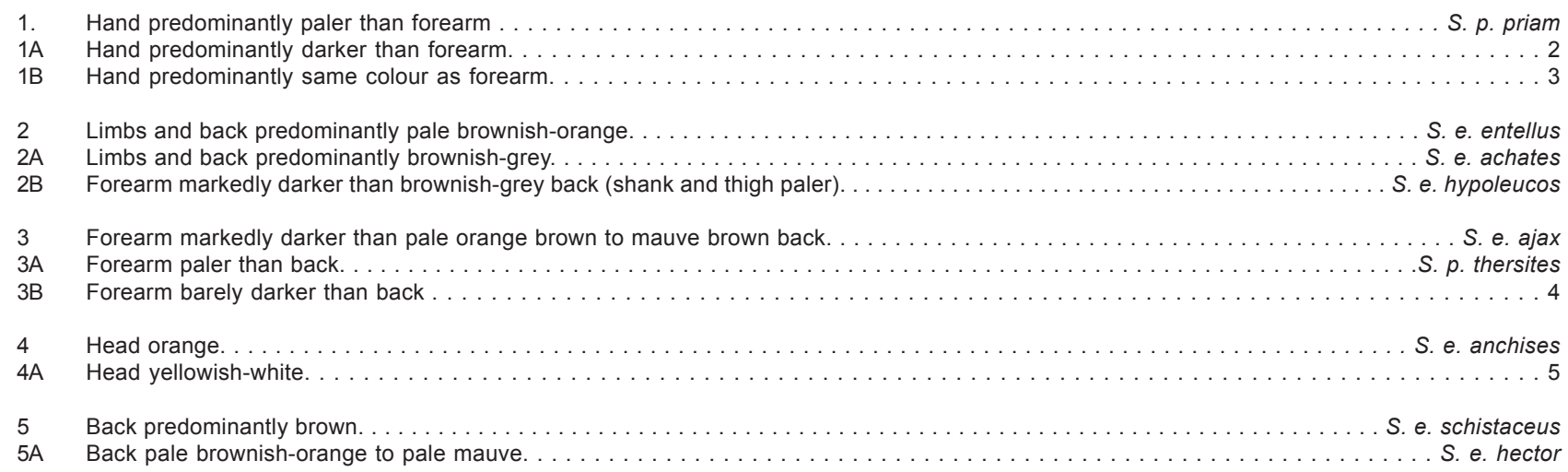

\section{Appendix 1}

Mode of tail carriage variation in Semnopithecus entellus and S. priam arranged according to the revised subspecific classification with a gazetteer of the localities from which data are available.

Roonwal (1979a) distinguished two principal modes of tail carriage by a langur when walking or standing on all fours: (I) forwardlooped and (II) backward-looped. He subcategorized the former as (IA) tail-tip touching the back or trailing down the flank (Fig. 1) and (IB) tail-tip suspended above the back (Fig. 2). He subcategorized backwardlooped tail carriage as (IIA) distal section of loop relatively long and pendulous (Fig. 3) and (IIB) distal section shorter and backward-directed or drooping obliquely. In IA the loop is roughly D-shaped (the straight side of the letter $D$ being formed by the back) or closed; in IB and IIA the tail is roughly Ushaped (the letter $U$ rotated onto its side in IB and inverted in IIA); while in IIB it is roughly $\mathrm{S}$-shaped. The subsequent discovery that tail carriage by langurs at Bharuch (Gujarat, India) differs from the Himalayan mode (IB) only in that the tail-tip is straight or drooped (Fig. 4) rather than normally out-curved, obliged Roonwal (1981b, pp. 35-36) to modify these subcategories. He included the Bharuch mode in IA.

Locality data on tail carriage variation in Semnopithecus entellus and S. priam arranged by subspecies

\section{Semnopithecus entellus entellus} (Dufresne, 1797)

Bagra; Baida; Bhagalpur, village $40 \mathrm{~km}$ west of; Bhubaneswar; Chandaka; Chandikhole; Dakshineswar; Dasapalla; Jeypore, road $16 \mathrm{~km}$ southeast of; Khandagiri; Madanpur; Narayanee; Narayanpur; Nirmaljhar; Orcha; Phringia; Sankarkhole; Sasaram; Tadoba National Park; Tikarpada: IA.

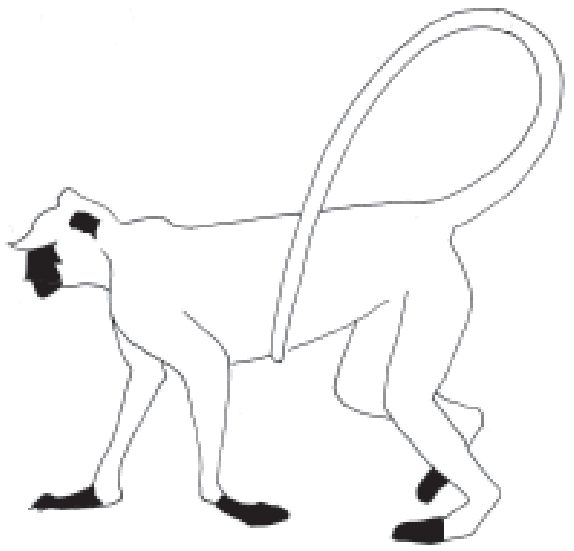

Figure 1. Langur tail carriage (IA) at Jodhpur, Rajasthan

(after Roonwal, 1979a, pl. 3, fig. 1).

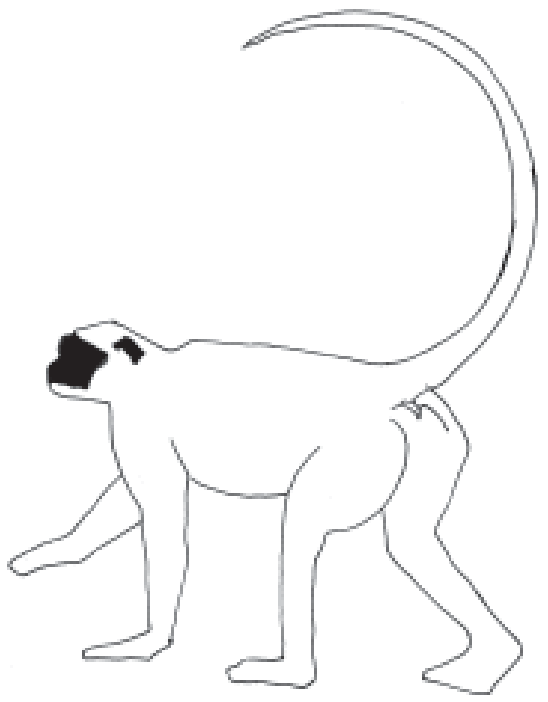

Figure 3. Langur tail carriage (IA, according to Roonwal, 1981b, 1984) at Bharuch, Gujarat

(after Roonwal, 1981b, pl. 1, fig. 5).

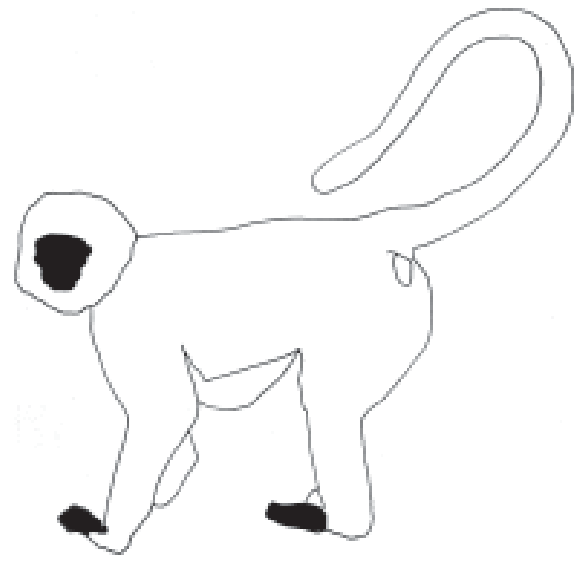

Figure 2. Langur tail carriage (IB) at Mussoorie, Uttaranchal

(adapted from Roonwal, 1979b, pl. 1).

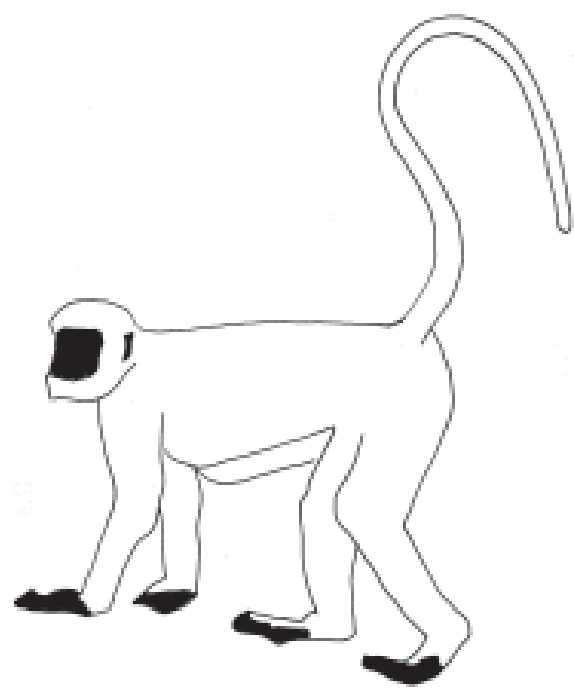

Figure 4. Langur tail carriage (IIA) at Mahabaleshwar, Maharashtra (after Roonwal, 1981b, pl. 1, fig. 12). 
Semnopithecus entellus achates (Pocock, 1928)

Ajmer; Alwar; Bharuch (possibly S. e. anchises); Chakia (possibly S. e. entellus); Debari; Etah; Gautampura Road; Jabalpur; Jaipur; Jodhpur; Kakori; Kanha National Park; Mount Abu; Omkareshwar Road; Pench National Park; Pushkar Lake; Ramtek; Sariska; Sikandra; Vadodara (possibly S. e. anchises): IA. Dandeli; Dharwad (possibly S. e. anchises); Pune; Surat: IIA.

\section{Semnopithecus entellus ajax (Pocock, 1928)}

Melemchi; Rolla Bhandar: both IB. The populations at both localities may be intermediate with Semnopithecus entellus schistaceus but there is no unequivocal evidence that the mode of tail carriage differs in S. e. ajax.

\section{Semnopithecus entellus anchises Blyth,} 1844

Arni, $15 \mathrm{~km}$ southeast of; Eluru; Hewari; Rajahmundry: IA. Arni, $5 \mathrm{~km}$ southeast of: IA, IB, IIA. Lonar, Lake: IIA.

\section{Semnopithecus entellus hector (Pocock, 1928)}

Amdanda (Corbett N.P.); Azamgarh (possibly intermediate with S. e. achates); Bhimtal; Dhikala (Corbett N.P.); Gorakhnath Temple (possibly intermediate with S. e. achates); Hardwar; Kusmi Forest (possibly intermediate with S. e. achates); Mohaddipur North (possibly intermediate with S. e. achates); Rajaji National Park: IB.

\section{Semnopithecus entellus hypoleucos} Blyth, 1841

Mahabaleshwar (possibly S. e. achates or intermediate): IIA.

\section{Semnopithecus entellus schistaceus Hodgson, 1841}

Asarori Forest (possibly S. e. hector); Chail; Charhabra; Chopta (possibly S. e. hector); Gomeri Nallah; Mandal (possibly S. e. hector); Mussoorie; Nandprayag (possibly S. e. hector); Phata (possibly S. e. hector); Rudraprayag (possibly S. e. hector); Shimla; Shogran (Hazara District); Thano Forest (possibly S. e. hector); Zahil Nallah: all IB except Shogran where data on tail carriage derives solely from Roberts' (1977, p. 88; 1997 , p. 128) figure probably based wholly or partly on a Northern Plains langur with the IA mode of tail carriage.

Semnopithecus priam priam Blyth, 1844 Bandipur Wildlife Sanctuary; Basavanbetta (possibly S. e. achates); Mudumalai Wildlife Sanctuary: IIA.

Semnopithecus priam thersites (Blyth, 1848)

Papanasam Camp (Mundanthurai); Polonnaruwa: IIB.

\section{Gazetteer}

(When available, coordinates have been obtained from the U.S. Board on Geographic Names: India, 2 vols., Washington, D.C., 1952, 787pp.)

Abu, Mount. See Mount Abu

Ajmer (26을 $\left.27^{\prime} \mathrm{N} 74^{\circ} 38^{\prime} \mathrm{E}\right)$, Rajasthan, India (Roonwal, 1979a, pp. 245, 248): Semnopithecus entellus achates (IA).

Alwar $\left(27^{\circ} 34^{\prime} \mathrm{N} 76^{\circ} 36^{\prime} \mathrm{E}\right)$, Rajasthan, India (Vogel, in Roonwal, 1979a, p. 245): Semnopithecus entellus achates (IA).

Amdanda (c. $\left.29^{\circ} 36^{\prime} \mathrm{N} 79^{\circ} 10^{\prime} \mathrm{E}\right), 300$ m, Nainital District, Corbett National Park, Uttaranchal, India (Roonwal, 1979a, p. 247, fig. 2; 1979b, pp. 51-52, pls. 2-3; 1981b, pl. 2): Semnopithecus entellus hector (IB)

Arni, $5 \mathrm{~km}$ southeast of $\left(20^{\circ} 00^{\prime} \mathrm{N} 78^{\circ} 00^{\prime} \mathrm{E}\right)$, Yavatmal District, Maharashtra, India (Roonwal \& Pirta, 1984 p. 24, pl. 1; Roonwal et al., 1984, pp. 16, 19, 22, pl. 1, fig. 3): Semnopithecus entellus anchises (IA, IB, IIA).

Arni, $15 \mathrm{~km}$ southeast of $\left(20^{\circ} 02^{\prime} \mathrm{N} 78^{\circ} 07^{\prime} \mathrm{E}\right)$ Yavatmal District, Maharashtra, India (Roonwal \& Pirta, 1984, p. 24, pl. 1; Roonwal et al., 1984, pp. 16, 19, pl. 1, fig. 1): Semnopithecus entellus anchises (IA).

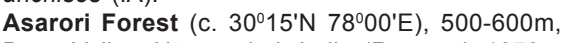
Doon Valley, Uttaranchal, India (Roonwal, 1979a, p. 247, fig. 2; 1979b, p. 51): Semnopithecus entellus schistaceus (possibly S. e. hector) (IB).

Azamgarh (26영 $\left.83^{\circ} 11^{\prime} \mathrm{E}\right)$, Uttar Pradesh, India (Singh, in Roonwal, 1981b, p. 27; 1984, pp. 309310): Semnopithecus entellus hector (possibly intermediate with S. e. achates) (IB).

Bagra (18050'N 82 $\left.{ }^{\circ} 39^{\prime} \mathrm{E}\right)$, Koraput District, Orissa, India (Roonwal \& Pirta, 1984, p. 23; Roonwal et al. 1984, pp. 18, 21): Semnopithecus entellus entellus (IA).

Baida $\left(20^{\circ} 20^{\prime} \mathrm{N} 84^{0} 15^{\prime} \mathrm{E}\right)$, Phulbani District, Orissa, India (Roonwal \& Pirta, 1984, p. 23; Roonwal et al. 1984, pp. 18, 21): Semnopithecus entellus entellus (IA)

Bandipur Wildlife Sanctuary $\left(11^{\circ} 45^{\prime} N\right.$ 7 $\left.77^{\circ} 30^{\prime} E\right)$, Karnataka, India (Nagabhushan, in Roonwal, 1980, p. 180 , figs. 2-3, pl. 1; 1981b, p. 34; Roonwal et al., 1984, pp. 18, 20, fig. 2): Semnopithecus priam priam (IIA).

Basavanbetta (c. $12^{\circ} 30^{\prime} \mathrm{N} 77^{\circ} 20^{\prime} \mathrm{E}$ ), near Kanakpura, Bangalore District, Karnataka, India (Gadgil \& Sharatchandra, in Roonwal, 1981b, p. 27; Roonwal et al., 1984, p. 18): Semnopithecus priam priam (possibly S. e. achates) (IIA).

Bhagalpur, village $40 \mathrm{~km}$ west of (c. $25^{0} 15^{\prime} \mathrm{N}$ $86^{\circ} 50^{\prime} \mathrm{E}$ ), Bhagalpur District, Bihar, India (Shah, in Roonwal, 1979a, p. 246): Semnopithecus entellus entellus (IA).

Bharuch $\left(21^{\circ} 42^{\prime} \mathrm{N} 72^{\circ} 58^{\prime} \mathrm{E}\right)$, Gujarat, India (Makwana, in Roonwal, 1981b, pp. 27, 30, 36, pl. 1; Roonwal et al., 1984, pp. 16, 22): Semnopithecus entellus achates (possibly S. e. anchises) (IA). Bhimtal $\left(29^{\circ} 21^{\prime} \mathrm{N} 79^{\circ} 34^{\prime} \mathrm{E}\right), 1100 \mathrm{~m}$, Uttaranchal India (Vogel, in Roonwal, 1979a, p. 247, fig. 2 1979b, p. 51, pl. 1): Semnopithecus entellus hector (IB).

Bhubaneswar $\left(20^{\circ} 14^{\prime} \mathrm{N} 85^{\circ} 50^{\prime} \mathrm{E}\right)$, Orissa, India (Pirta, in Roonwal, 1981b, pp. 27, 30; Roonwal et al., 1984, pp. 18, 21-22): Semnopithecus entellus entellus (IA)

Broach. See Bharuch.

Calcutta. See Dakshineswar and Madanpur. Chail (305' $\left.\mathrm{N} 77^{0} 11^{\prime} \mathrm{E}\right), 2400 \mathrm{~m}$, "30km east" $[13 \mathrm{~km}$ south] of Shimla, Shimla District, Himachal Pradesh, India (Roonwal, 1981b, p. 27): Semnopithecus entellus schistaceus (IB)

Chakia $\left(25^{\circ} 03^{\prime} \mathrm{N} 83^{\circ} 13^{\prime} \mathrm{E}\right), 40 \mathrm{~km}$ southeast of Varanasi, Uttar Pradesh, India (Pirta, in Roonwal, 1981b, p. 27): Semnopithecus entellus achates (possibly S. e. entellus) (IA).

Chandaka $\left(20^{\circ} 22^{\prime} \mathrm{N} 85^{\circ} 46^{\prime} \mathrm{E}\right)$, Puri District, Orissa India (Roonwal \& Pirta, 1984, p. 23; Roonwal et al., 1984, pp. 18, 21): Semnopithecus entellus entellus (IA).

Chandikhole $\left(20^{\circ} 40^{\prime} \mathrm{N} 86^{\circ} 05^{\prime} \mathrm{E}\right)$, Cuttack District, Orissa, India (Roonwal \& Pirta, 1984, p. 23; Roonwal et al., 1984, pp. 18, 21): Semnopithecus entellus entellus (IA).

Charhabra $\left(31^{\circ} 05^{\prime} \mathrm{N} 77^{\circ} 222^{\prime} \mathrm{E}\right), 2600 \mathrm{~m}, 1 \mathrm{~km}$ west of Kufri, Shimla District, Himachal Pradesh, India (Roonwal, 1981b, p. 27): Semnopithecus entellus schistaceus (IB)

Chilla Wildlife Sanctuary. See Rajaji National Park. Chopta $\left(30^{\circ} 27^{\prime} N 7^{\circ} 11^{\prime} E\right), 2680 m$, Chamoli District, Garhwal, Uttaranchal, India (Verma, in Roonwal, 1979b, pp. 51, 55): Semnopithecus entellus schistaceus (possibly S. e. hector) (IB).

Corbett National Park. See Amdanda and Dhikala Dakshineswar $\left(22^{\circ} 35^{\prime} \mathrm{N} 88^{\circ} 24^{\prime} \mathrm{E}\right), 12 \mathrm{~km}$ north of Kolkata, West Bengal, India (Roonwal, 1979a, p. 246; Roonwal et al., 1984, p. 18): Semnopithecus entellus entellus (IA).

Dandeli $\left(15^{\circ} 15^{\prime} \mathrm{N} 74^{\circ} 37^{\prime} \mathrm{E}\right)$, North Kanara, Karnataka, India (Kacker, in Roonwal, 1979a, p. 247; Roonwal et al., 1984, p. 18): Semnopithecus entellus achates (IIA).

Dasapalla $\left(20^{\circ} 25^{\prime} \mathrm{N} 84^{\circ} 50^{\prime} \mathrm{E}\right)$, Puri District, Orissa, India (Roonwal \& Pirta, 1984, p. 23; Roonwal et al. 1984, pp. 18, 21): Semnopithecus entellus entellus (IA).

Debari $\left(24^{\circ} 37^{\prime} \mathrm{N} 73^{\circ} 49^{\prime} \mathrm{E}\right), 15 \mathrm{~km}$ northeast of Udaipur, Rajasthan, India (Roonwal, 1979a, p. 245; 1981a, pl. 2; 1981b, pl. 1; Roonwal et al., 1984, p. 16): Semnopithecus entellus achates (IA).

Dehra Dun. See Asarori and Thano Forests

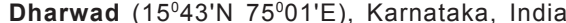
(Yoshiba, Sugiyama and Parthasarathy, cited by Roonwal, 1979a, pp. 247-248; 1980, p. 180, figs. 23; 1981b, p. 34; Roonwal et al., 1984, p. 18): Semnopithecus entellus achates (possibly S. e. anchises) (IIA).

\section{Dharwar. See Dharwad.}

Dhikala $\left(29^{\circ} 39^{\prime} \mathrm{N} 78^{\circ} 55^{\prime} \mathrm{E}\right)$, c. $390 \mathrm{~m}$, Pauri District, Corbett National Park, Uttaranchal, India (Roonwal, 1979 a, p. 247 , fig. 2 ; 1979 b, p. 51 , pl. 3): Semnopithecus entellus hector (IB).

Eluru $\left(16^{\circ} 43^{\prime} \mathrm{N} 8^{\circ} 01^{\circ} \mathrm{E}\right)$, West Godavari District, Andhra Pradesh, India (Roonwal \& Pirta, 1984, pp. 24, 26; Roonwal et al., 1984, pp. 18, 20, 22, fig. 2): Semnopithecus entellus anchises (IA).

Etah $\left(27^{\circ} 38^{\prime} \mathrm{N} 78^{\circ} 40^{\prime} \mathrm{E}\right)$, Uttar Pradesh, India (Makwana, in Roonwal, 1979a, p. 246): Semnopithecus entellus achates (IA).

Gautampura Road (c. $23^{\circ} 10^{\prime} N 7^{\circ} 40^{\prime} E$ ), on the railway line between Indore and Ratlam, Madhya Pradesh, India (Roonwal, 1979a, p. 246; 1981b, p. 30; Roonwal et al., 1984, p. 16): Semnopithecus entellus achates (IA).

Gomeri Nallah (c. $\left.34^{\circ} 09^{\prime} \mathrm{N} 74^{\circ} 55^{\prime} \mathrm{E}\right), 3000 \mathrm{~m}$, proposed Ovra Sanctuary, about $28 \mathrm{~km}$ southeast of Srinagar, Jammu and Kashmir, India (Tak \& Kumar, 1984, p. 203): Semnopithecus entellus schistaceus (IB).

Gorakhnath Temple (c. $26^{\circ} 45^{\prime} \mathrm{N} 83^{\circ} 24^{\prime} \mathrm{E}$ ), c. $4 \mathrm{~km}$ northwest of Gorakhpur, Uttar Pradesh, India (Roonwal, 1981b, p. 27, pl. 2; 1984, p. 309, pls. 1 2): Semnopithecus entellus hector (possibly intermediate with S. e. achates) (IB).

Gorakhpur. See Gorakhnath Temple and Mohaddipur North.

Hardwar $\left(29^{\circ} 58^{\prime} \mathrm{N} 78^{\circ} 10^{\prime} \mathrm{E}\right)$, Uttaranchal, India (Roonwal, 1979a, p. 247, fig. 2): Semnopithecus entellus hector (IB)

Hazara District. See Shogran.

Hewari $\left(20^{\circ} 22^{\prime} N\right.$ 78 $\left.12^{\prime} E\right)$, Yavatmal District, Maharashtra, India (Roonwal \& Pirta, 1984, p. 24, 
pl. 1; Roonwal et al., 1984, pp. 16, 19, 22, pl. 1, fig. 6): Semnopithecus entellus anchises (IA).

Jabalpur (23010'N 79 $\left.57^{\prime} E\right)$, Madhya Pradesh, India (Khajuria, in Roonwal, 1979a, p. 246, pl. 1; 1981b, p. 30; Roonwal et al., 1984, p. 16): Semnopithecus entellus achates (IA).

Jaipur $\left(26^{\circ} 55^{\prime} \mathrm{N} 75^{\circ} 49^{\prime} E\right)$, Rajasthan, India (Roonwal, 1979a, pp. 245, 248): Semnopithecus entellus achates (IA)

Jeypore, road $16 \mathrm{~km}$ southeast of $\left(18^{\circ} 48^{\prime} \mathrm{N} 82^{\circ} 38^{\prime} \mathrm{E}\right)$, Koraput District, Orissa, India (Roonwal \& Pirta, 1984, p. 23; Roonwal et al., 1984, pp. 18, 21): Semnopithecus entellus entellus (IA).

Jodhpur $\left(26^{\circ} 17^{\prime} \mathrm{N} 73^{\circ} 02^{\prime} \mathrm{E}\right)$, Rajasthan, India (Roonwal, 1979a, pp. 245, 248, pls. 2-3; 1981b, pls. 1, 3; Roonwal \& Makwana, 1981, pl. 6; Roonwal \& Pirta, 1984, pp. 25-26; Roonwal et al., 1984, p. 20 fig. 2): Semnopithecus entellus achates (IA). Kakori $\left(26^{\circ} 54^{\prime} \mathrm{N} 80^{\circ} 48^{\prime} \mathrm{E}\right)$, Uttar Pradesh, India (Jay, Yoshiba and Dolhinow, cited by Roonwal, 1979a, p. 246): Semnopithecus entellus achates (IA)

Kanha National Park $\left(22^{\circ} 17^{\prime} \mathrm{N} 80^{\circ} 37^{\prime} \mathrm{E}\right)$, Mandla District, Madhya Pradesh, India (Krishnan, cited by Roonwal, 1979a, p. 246; Roonwal et al., 1984, p. 16): Semnopithecus entellus achates (IA). Kaukori. See Kakori.

Khandagiri $\left(20^{\circ} 16^{\prime} \mathrm{N} 85^{\circ} 47^{\prime} \mathrm{E}\right)$, Puri District, Orissa, India (Roonwal \& Pirta, 1984, p. 23, pl. 1; Roonwal et al., 1984, pp. 18, 20-21, fig. 2): Semnopithecus entellus entellus (IA).

Kolkata. See Dakshineswar and Madanpur.

Kusmi Forest (c. $26^{\circ} 45^{\prime} \mathrm{N} 83^{\circ} 30^{\prime} \mathrm{E}$ ), 8km east of Gorakhpur, Uttar Pradesh, India (Roonwal, 1981b, p. $27 ; 1984$, p. 309): Semnopithecus entellus hector (possibly intermediate with S. e. achates) (IB)

Lonar, Lake shore (c. 19059'N 76032'E), Buldana District, Maharashtra, India (Tiwari, in Roonwal, 1981b, pp. 27, 30; Roonwal et al., 1984, p. 18): Semnopithecus entellus anchises (IIA).

Madanpur $\left(23^{\circ} 01^{\prime} \mathrm{N} 88^{\circ} 29^{\prime} \mathrm{E}\right)$, Nadia District, 52km northeast of Kolkata, West Bengal, India (Roonwal, 1979a, p. 246; Roonwal et al., 1984, p. 18): Semnopithecus entellus entellus (IA).

Mahabaleshwar $\left(17^{\circ} 55^{\prime} \mathrm{N} 73^{\circ} 40^{\prime} \mathrm{E}\right)$, Maharashtra, India (Makwana \& Kankane, in Roonwal, 1981b pp. 27, 34, pl. 1; Roonwal et al., 1984, p. 18) Semnopithecus entellus hypoleucos (possibly S. e. achates or intermediate) (IIA)

Mandal $\left(30^{\circ} 27^{\prime} \mathrm{N} 79^{\circ} 17^{\prime} \mathrm{E}\right), 1490 \mathrm{~m}$, Chamoli District, Garhwal, Uttaranchal, India (Verma, in Roonwal, 1979b, pp. 51, 55): Semnopithecus entellus schistaceus (If this is the provenance of AMNH.32653 then the local subspecies is $S$. e. hector) (IB)

Melemchi $\left(28^{\circ} 03^{\prime} \mathrm{N} 85^{\circ} 33^{\prime} \mathrm{E}\right), 2600 \mathrm{~m}$, Helambu Valley, Sindu District, Nepal (Bishop, cited by Roonwal, 1979a, p. 247, fig. 5; 1979b, p. 54, fig. 5): Semnopithecus entellus ajax (IB).

Mohaddipur North (c. $26^{\circ} 45^{\prime} \mathrm{N} 83^{\circ} 24^{\prime} \mathrm{E}$ ), near Gorakhpur, Uttar Pradesh, India (Roonwal, 1981b, p. 27, pl. 2; 1984, p. 309, pls. 1-2): Semnopithecus entellus hector (possibly intermediate with $S$. e. achates) (IB)

Mount Abu $\left(24^{\circ} 36^{\prime} \mathrm{N} 72^{\circ} 42^{\prime} \mathrm{E}\right)$, c. $1200 \mathrm{~m}$, Rajasthan India (Hrdy, cited by Roonwal, 1979a, p. 245): Semnopithecus entellus achates (IA).

Mudumalai Wildlife Sanctuary (c. $11^{\circ} 34^{\prime} \mathrm{N}$ $76^{\circ} 32^{\prime} E$ ), c. $2200 \mathrm{~m}$, Tamil Nadu, India (Chennai Zoo specimen) (Roonwal, 1979a, pp. 247-248, pls. 2-3; 1980 , p. 181 , fig. 3, pl. 1; 1981a, pl. 2; 1981 b, p. 34 Roonwal et al., 1984, p. 19): Semnopithecus priam priam (IIA).

Mundanthurai. See Papanasam Camp.

Mussoorie $\left(30^{\circ} 27^{\prime} \mathrm{N} 78^{\circ} 05^{\prime} \mathrm{E}\right)$, c. $1800 \mathrm{~m}$, Uttaranchal, India (Makwana, in Roonwal, 1979a, p. 247, pl. 3; 1979b, p. 51, pl. 1; 1981a, pl. 2; Roonwal et al., 1984, p. 20, fig. 2): Semnopithecus entellus schistaceus (IB).

Nainital District. See Amdanda and Bhimtal.
Nandprayag $\left(30^{\circ} 20^{\prime} \mathrm{N} 79^{\circ} 21^{\prime} \mathrm{E}\right), 900 \mathrm{~m}$, Chamoli District, Garhwal, Uttaranchal, India (Verma, in Roonwal, 1979b, pp. 51, 55): Semnopithecus entellus schistaceus (possibly S. e. hector) (IB).

Narayanee $\left(19^{\circ} 45^{\prime} \mathrm{N} 85^{\circ} 08^{\prime} \mathrm{E}\right)$, Ganjam District, Orissa, India (Roonwal \& Pirta, 1984, p. 23; Roonwal et al., 1984, pp. 18, 21): Semnopithecus entellus entellus (IA).

Narayanpur $\left(23^{\circ} 16^{\prime} \mathrm{N} 88^{\circ} 30^{\prime} \mathrm{E}\right)$, Burdwan District, $45 \mathrm{~km}$ east of Burdwan, West Bengal, India (Sinha, in Roonwal, 1979a, p. 246; Roonwal et al., 1984, p. 18): Semnopithecus entellus entellus (IA).

Nirmaljhar $\left(19^{\circ} 35^{\prime} \mathrm{N} 85^{\circ} 05^{\prime} \mathrm{E}\right)$, Ganjam District, Orissa, India (Roonwal \& Pirta, 1984, p. 23; Roonwal et al., 1984, pp. 18, 21): Semnopithecus entellus entellus (IA).

Omkareshwar Road (c. $22^{\circ} 05^{\prime} \mathrm{N} 76^{\circ} 10^{\prime} \mathrm{E}$ ), on the railway line between Indore and Khandwa, Madhya Pradesh, India (Roonwal, 1979a, p. 246; 1981b, p. 30; Roonwal et al., 1984, p. 16): Semnopithecus entellus achates (IA).

Orcha $\left(19^{\circ} 22^{\prime} \mathrm{N} 81^{\circ} 12^{\prime} \mathrm{E}\right)$, Bastar District, Madhya Pradesh, India: Semnopithecus entellus entellus. Categorized as IIA by Roonwal (1979a, pp. 247$249 ; 1980$, p. 180 , figs. $2-3$; 1981 b, pp. 30,34 ) but corrected to IA by Dolhinow (in Roonwal et al., 1984, pp. 16, 19-20, 23, fig. 2).

Papanasam Camp $\left(8^{\circ} 42^{\prime} \mathrm{N} 77^{\circ} 23^{\prime} \mathrm{E}\right), 460 \mathrm{~m}$, Mundanthurai Wildlife Sanctuary, Tirunelveli District, Tamil Nadu, India (Kurup, in Roonwal, 1979a, p. 248 , pl. 1; 1980 , p. 181, fig. 3, pl. 1; 1981b, pp. 3334; Roonwal et al., 1984, p. 19): Semnopithecus priam thersites (IIB)

Pench National Park (c. $21^{0} 35^{\prime} N 79^{\circ} 10^{\prime} E$ ), Nagpur District, Maharashtra, India (Khajuria, in Roonwal, 1979a, pp. 246 249, pl. 3; Roonwal et al., 1984, p. 16): Semnopithecus entellus achates (IA)

Phata $\left(30^{\circ} 35^{\prime} \mathrm{N} 79^{\circ} 03^{\prime} \mathrm{E}\right), 1525 \mathrm{~m}$, Chamoli District, Garhwal, Uttaranchal, India (Verma, in Roonwal, 1979b, pp. 51, 55): Semnopithecus entellus schistaceus (possibly S. e. hector) (IB).

Phringia $\left(20^{\circ} 21^{\prime} \mathrm{N} 84^{\circ} 07^{\prime} \mathrm{E}\right)$, Phulbani District, Orissa, India (Roonwal \& Pirta, 1984, p. 23; Roonwal et al., 1984, pp. 18, 21): Semnopithecus entellus entellus (IA).

Polonnaruwa $\left(7^{\circ} 56^{\prime} \mathrm{N} 81^{\circ} 00^{\prime} \mathrm{E}\right)$, Sri Lanka (Jay \& Ripley, cited by Roonwal, 1979a, p. 248; 1980, p. 181, figs. 2-3; 1981b, pp. 33-34; Roonwal et al., 1984, p. 19): Semnopithecus priam thersites (IIB). Poona. See Pune.

Pune (18 $\left.32^{\prime} \mathrm{N} 73^{\circ} 52^{\prime} \mathrm{E}\right), 570 \mathrm{~m}$, Maharashtra, India (Roonwal, 1979a, pp. 247-249, pls. 2-3; 1980, p. 180, figs. 2-3, pl. 1; 1981a, pl. 2; 1981b, pp. 33-35; Roonwal et al., 1984, p. 18): Semnopithecus entellus achates (possibly intermediate with $S$. e. hypoleucos) (IIA).

Pushkar Lake $\left(26^{\circ} 30^{\prime} \mathrm{N} 74^{\circ} 33^{\prime} \mathrm{E}\right), 15 \mathrm{~km}$ northwest of Ajmer, Rajasthan, India (Roonwal, 1979a, p. 245): Semnopithecus entellus achates (IA).

Rajahmundry $\left(16^{\circ} 59^{\prime} \mathrm{N} 81^{\circ} 47^{\prime} \mathrm{E}\right)$, East Godavari District, Andhra Pradesh, India (Roonwal \& Pirta, 1984, pp. 24, 26; Roonwal et al., 1984, pp. 18, 20, 22, fig. 2): Semnopithecus entellus anchises (IA). Rajaji National Park (c. $30^{\circ} 10^{\prime} \mathrm{N} 78^{\circ} 00^{\prime} \mathrm{E}$ ), c. 300$600 \mathrm{~m}$, Pauri District, Uttaranchal, India (Roonwal, 1979 a, p. 247 , fig. 2 ; 1979 b, p. 51, pl. 3; Laws \& Laws, 1984, fig. 1): Semnopithecus entellus hector (possibly intermediate with S. e. schistaceus) (IB). Ramtek $\left(21^{\circ} 24^{\prime} \mathrm{N} 79^{\circ} 20^{\prime} \mathrm{E}\right)$, Nagpur District, $40 \mathrm{~km}$ northeast of Nagpur, Maharashtra, India (Mukherjee, in Roonwal, 1979a, pp. 246, 249; Roonwal et al., 1984, p. 16): Semnopithecus entellus achates (IA). Rolla Bhandar (c. $31^{\circ} 50^{\prime} \mathrm{N} 77^{\circ} 40^{\prime} \mathrm{E}$ ), 2100m, Kullu District, Himachal Pradesh, India (Tak, in Roonwal, 1981b, p. 27): Semnopithecus entellus ajax (possibly S. e. schistaceus) (IB)

Rudraprayag $\left(30^{\circ} 17^{\prime} \mathrm{N} 78^{\circ} 59^{\prime} \mathrm{E}\right), 610 \mathrm{~m}$, Pauri District, Garhwal, Uttaranchal, India (Verma, in Roonwal, 1979b, pp. 51, 55): Semnopithecus entellus schistaceus (possibly S. e. hector) (IB).

Sankarkhole $\left(20^{\circ} 18^{\prime} \mathrm{N} 84^{\circ} 17^{\prime} \mathrm{E}\right)$, Phulbani District, Orissa, India (Roonwal \& Pirta, 1984, p. 23; Roonwal et al., 1984, pp. 18, 21): Semnopithecus entellus entellus (IA).

Sariska $\left(27^{\circ} 24^{\prime} \mathrm{N} 76^{\circ} 24^{\prime} \mathrm{E}\right)$, Rajasthan, India (Vogel, in Roonwal, 1979a, p. 245): Semnopithecus entellus achates (IA).

Sasaram, near (c. $24^{\circ} 57^{\prime} \mathrm{N} 84^{\circ} 02^{\prime} \mathrm{E}$ ), Rohtas (formerly Shahabad) District, Bihar, India (Mukherjee, in Roonwal, 1979a, p. 246): Semnopithecus entellus entellus (IA).

Shimla $\left(31^{\circ} 06^{\prime} \mathrm{N} 77^{\circ} 10^{\prime} \mathrm{E}\right), 1500-3200 \mathrm{~m}$, Himachal Pradesh, India (Sugiyama, cited by Roonwal, 1979a, p. 246 , fig. 5 ; 1979 b, p. 50 , fig. 5 ; 1981 b, pl. 2 ; 1984, p. 310, pl. 2): Semnopithecus entellus schistaceus (IB).

Shogran $\left(34^{\circ} 37^{\prime} N 73^{\circ} 28^{\prime} E\right)$, Hazara District. Pakistan: Semnopithecus entellus schistaceus. Accepted by Roonwal (1979a, p. 245; 1979b, p. 54) as IA from Roberts' (1977, p. 88; 1997, p. 128) figure but probably IB (see above).

Sikandra $\left(27^{0} 14^{\prime} \mathrm{N} 77^{\circ} 56^{\prime} \mathrm{E}\right)$, c. $12 \mathrm{~km}$ northwest of Agra, Uttar Pradesh, India (Roonwal, 1981b, p. 27): Semnopithecus entellus achates (IA).

Surat $\left(21^{\circ} 10^{\prime} \mathrm{N} 72^{\circ} 50^{\prime} \mathrm{E}\right)$, Gujarat, India (Makwana in Roonwal, 1981b, pp. 27, 30, 33-36, pl. 1; Roonwal et al., 1984, p. 18): Semnopithecus entellus achates (IIA)

Tadoba National Park (c. 20017'N 79015'E), Warora Taluk, Chandrapur District, Maharashtra, India (Krishnan, cited by Roonwal, 1979a, pp. 246, 249 1981 b, p. 30; Roonwal et al., 1984, p. 16): Semnopithecus entellus entellus (IA).

Taroba National Park. See Tadoba National Park. Thano Forest (c. 30 $\left.19^{\prime} \mathrm{N} 78^{\circ} 04^{\prime} \mathrm{E}\right), 500-600 \mathrm{~m}$, Doon Valley, Uttaranchal, India (Roonwal, 1979a, p. 247. fig. 2; 1979b, p. 51, pl. 3): Semnopithecus entellus schistaceus (possibly S. e. hector) (IB)

Tikarpada $\left(20^{\circ} 35^{\prime} \mathrm{N} 84^{\circ} 48^{\prime} \mathrm{E}\right)$, Dhenkanal District Orissa, India (Roonwal \& Pirta, 1984, p. 23; Roonwal et al., 1984, pp. 18, 21): Semnopithecus entellus entellus (IA).

Udaipur. See Debari.

Vadodara $\left(22^{\circ} 00^{\prime} N 73^{\circ} 16^{\prime} E\right)$, Baroda, Gujarat, India (Roonwal, 1979a, pp. 246, 249; 1981b, pp. 30, 36 Roonwal et al., 1984, p. 16): Semnopithecus entellus achates (possibly S. e. anchises) (IA).

Yeotmal District. See Arni and Hewari.

Zahil Nallah (c. $34^{0} 12^{\prime} \mathrm{N} 75^{\circ} 00^{\prime} \mathrm{E}$ ), 2285m, Dachigam National Park, about $20 \mathrm{~km}$ northeast of Srinagar, Jammu and Kashmir, India (Tak \& Kumar, 1984, p. 202): Semnopithecus entellus schistaceus (IB). 


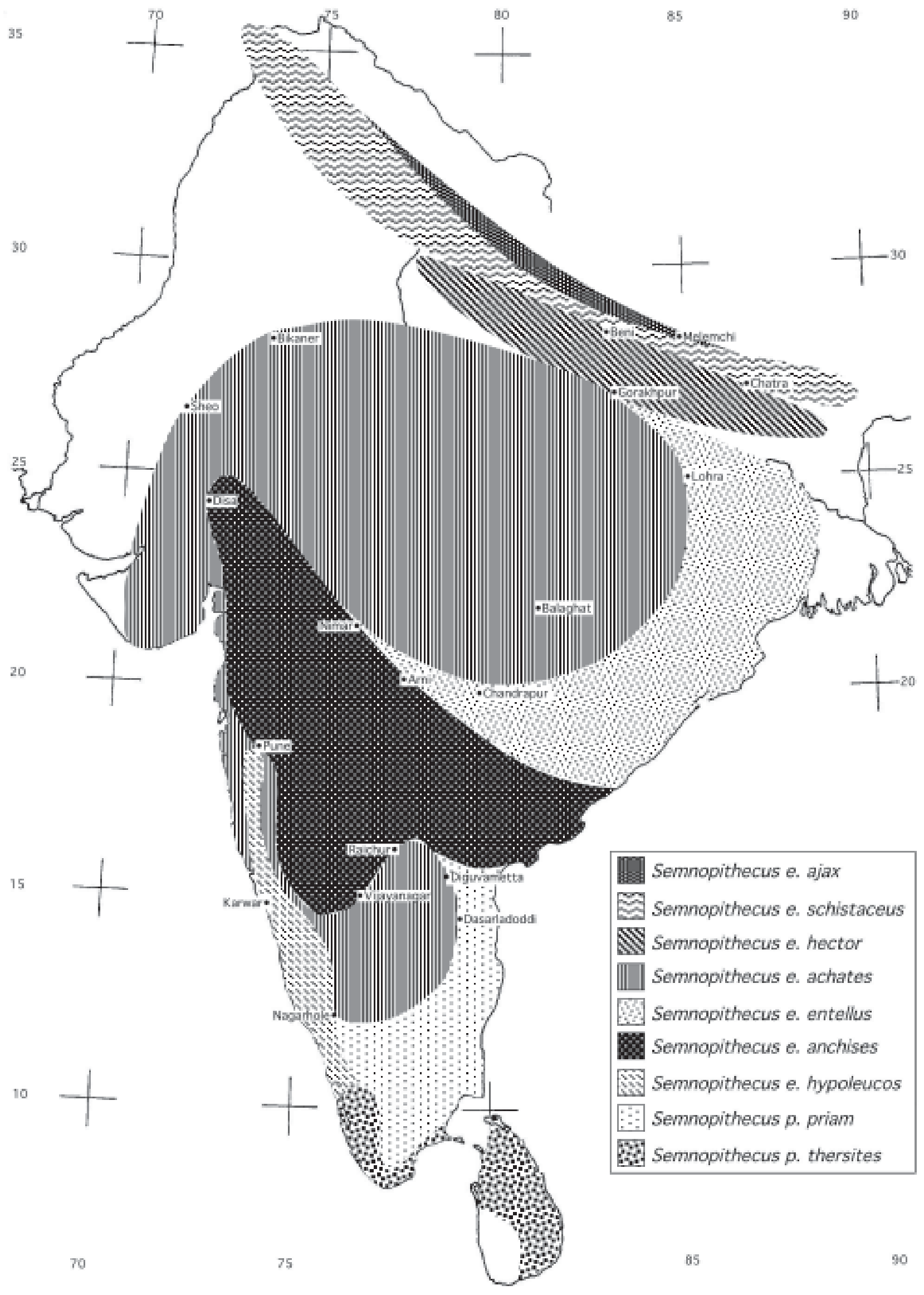

